\title{
Lignin Valorizations with Ni Catalysts for Renewable Chemicals and Fuels Productions
}

\author{
Xiao Chen ${ }^{1,+}\left(\mathbb{D}\right.$, Weixiang Guan ${ }^{1,+}+\mathbb{C}$, Chi-Wing Tsang $2, * \mathbb{C}$, Haoquan $\mathrm{Hu}^{3}$ and \\ Changhai Liang ${ }^{1, *}$ \\ 1 State Key Laboratory of Fine Chemicals \& Laboratory of Advanced Materials and Catalytic Engineering, \\ School of Chemical Engineering, Dalian University of Technology, Dalian 116024, China; \\ xiaochen@dlut.edu.cn (X.C.); wxguan199210@126.com (W.G.) \\ 2 Faculty of Science and Technology, Technological and Higher Education Institute of Hong Kong, \\ Hong Kong 999077, China \\ 3 State Key Laboratory of Fine Chemicals, Institute of Coal Chemical Engineering, \\ School of Chemical Engineering, Dalian University of Technology, Dalian 116024, China; hhu@dlut.edu.cn \\ * Correspondence: ctsang@vtc.edu.hk (C.-W.T.); changhai@dlut.edu.cn (C.L.); \\ Tel.: +852-2176-1843 (C.-W.T.); +86-(0)411-8498-6353 (C.L.) \\ + These authors contributed equally to this work.
}

Received: 26 April 2019; Accepted: 22 May 2019; Published: 28 May 2019

check for updates

\begin{abstract}
Energy and fuels derived from biomass pose lesser impact on the environmental carbon footprint than those derived from fossil fuels. In order for the biomass-to-energy and biomass-to-chemicals processes to play their important role in the loop of the circular economy, highly active, selective, and stable catalysts and the related efficient chemical processes are urgently needed. Lignin is the most thermal stable fraction of biomass and a particularly important resource for the production of chemicals and fuels. This mini review mainly focuses on lignin valorizations for renewable chemicals and fuels production and summarizes the recent interest in the lignin valorization over $\mathrm{Ni}$ and relevant bimetallic metal catalysts on various supports. Particular attention will be paid to those strategies to convert lignin to chemicals and fuels components, such as pyrolysis, hydrodeoxygenation, and hydrogenolysis. The review is written in a simple and elaborated way in order to draw chemists and engineers' attention to Ni-based catalysts in lignin valorizations and guide them in designing innovative catalytic materials based on the lignin conversion reaction.
\end{abstract}

Keywords: lignin; Ni catalysts; pyrolysis; hydrodeoxygenation; hydrogenolysis; review

\section{Introduction \& Scope of Study}

Climate change due to anthropogenic $\mathrm{CO}_{2}$ emissions and continuous depletion of raw materials and energy resources are all major hurdles to sustainable development. Energy and fuels derived from biomass can have lesser impact on the environmental carbon footprint than those derived from fossil fuels, especially if the resources are from renewable biomasses, such as wood and herbaceous (lignocellulosic) biomasses, corncob, or straw biomasses, etc. This is because even when the fuels are combusted, the $\mathrm{CO}_{2}$ emitted is offset and captured by the biomasses that produced the materials in the first place. The concept of circular economy has a significant impact on slowing down the rate of depletion of raw materials for products and energy consumption [1], in which it replaces the concept of "end-of-life" with restoration and shifts toward the utilization of renewable energy. Among the several generations of biorefinery, the 2nd generation, i.e., using woody and herbaceous biomasses, is probably the most promising route to produce renewable energy effectively and efficiently. The reason is that whether the lignocellulosic biomasses are freshly grown or from waste sources, they will not directly compete for food usage. In order for the biomass-to-energy and biomass-to-chemicals 
processes to play their important role in the loop of the circular economy, first, the process must be energy efficient itself [2]. Second, according to Anastas's second principle [3], atom economy should be maximized and excess starting materials which will not be contained in the final product should be avoided. Thus, developing highly active and selective catalysts and enzymes is an urgent need. Current technology for lignocellulosic valorization includes biochemical fermentation, chemical and thermochemical methods using enzymes and metal catalysts, respectively. Thermochemical methods, including combustion, pyrolysis, and gasification, and chemical methods, such as hydrodeoxygenation (HDO), hydrogenolysis, and oxidative cleavage, have the advantages of higher throughputs due to the short reaction time, and thus are more suitable for commercialized and industrialized scale-up.

Woody and herbaceous biomasses are large polymeric networks consisting of ca. 35-50\% cellulose, $25-30 \%$ hemicellulose (glucomannan and glucuronoxylan), and $15-30 \%$ of lignin (macromolecular polymer networks with interconnected phenylpropane and phenol units with various formula, e.g., $\left.\left(\mathrm{C}_{31} \mathrm{H}_{34} \mathrm{O}_{11}\right)_{n}\right)$ by weight. Lignin is one of the most thermal stable fractions and a particularly important resource for the production of chemicals and fuels. With careful design of the metal catalysts, either aromatic platform molecules, or fuels components such as naphthenes, can be preferentially produced in high yields and with high selectivity.

Over the past decade, numerous monometallic and bimetallic metal catalysts using both precious and base metal precursors on various supports have been reported to successfully convert lignin into valuable products. Transition metals such as Ni (price $=$ US $\$ 12.628 / \mathrm{kg}$ as of April 2019) are much more economically viable than precious metals such as $\mathrm{Pt}$ (price $=$ US $\$ 28,935 / \mathrm{kg}$ as of April 2019) [4]. In addition, the global warming potential of Ni from cradle to gate is estimated to be ca. $6.5 \mathrm{~kg} \mathrm{CO}$-eq/ $/ \mathrm{kg}$, as compared with 12,500 $\mathrm{kg} \mathrm{CO}_{2}$-eq/ $/ \mathrm{kg}$ for Pt metal [5]. Precious metal catalysts generally exhibited higher activity than non-noble metal catalysts, nonetheless, the incorporation of $\mathrm{Ni}$ into precious metal catalysts always exhibited outperforming activity and is superior to pure noble metal catalysts due to "synergistic" effects. In addition, among the several transition metal catalysts, such as $\mathrm{Ni}, \mathrm{Fe}, \mathrm{Cu}, \mathrm{Zn}$, and $\mathrm{Sn}, \mathrm{Ni}$-based catalysts showed the best activities and product selectivity towards the valorizations of lignin to produce renewable chemicals and fuels. There are several reviews published on the catalytic valorization of biomass, however, they mainly focused on the catalytic lignin transformation technologies in general. The literature based on the lignin valorizations over particular metal catalysts, such as Ni-based catalysts for renewable chemicals and fuels production, has not been covered yet and will be fully accounted in this review. This will provide a summary of the interest in the lignin valorization over $\mathrm{Ni}$ and relevant bimetallic metal catalysts on various supports, with particular attention paid to those strategies for converting lignin to chemicals and fuels components, such as pyrolysis, HDO, and hydrogenolysis. In addition, the review is written in simple and elaborate way in order to draw chemists and engineers' attention to Ni-based catalysts in lignin valorizations and guide them in designing innovative catalytic materials based on the reaction.

\section{Ni-Based Catalysts for Pyrolysis of Lignin}

Pyrolysis is a key thermal conversion technology for the conversion of lignin to pyrolytic oil, syngas, and solid residue (char), and is an effective and economic utilization of biomass. However, due to the difficulty to decompose and the generation of high amounts of solid residue for the lignin pyrolysis, it is still a challenge for utilization of lignin with high efficiency by heat [6,7]. Introducing the catalyst into the thermal conversion process can significantly improve the yield of oil and gas for the pyrolytic decomposition of lignin. Figure 1 shows the schematic diagram of the experimental system for the catalytic pyrolysis of lignin [8]. In this process, Ni-based catalysts are the most effective, which can decrease the yield of tar and the oxygen content in the bio-oil significantly and increase the gas yield, which is an especially important process for the production of hydrogen. This section is a review on studies related to catalytic pyrolysis of lignin to produce oil and gas over Ni-based catalysts. 


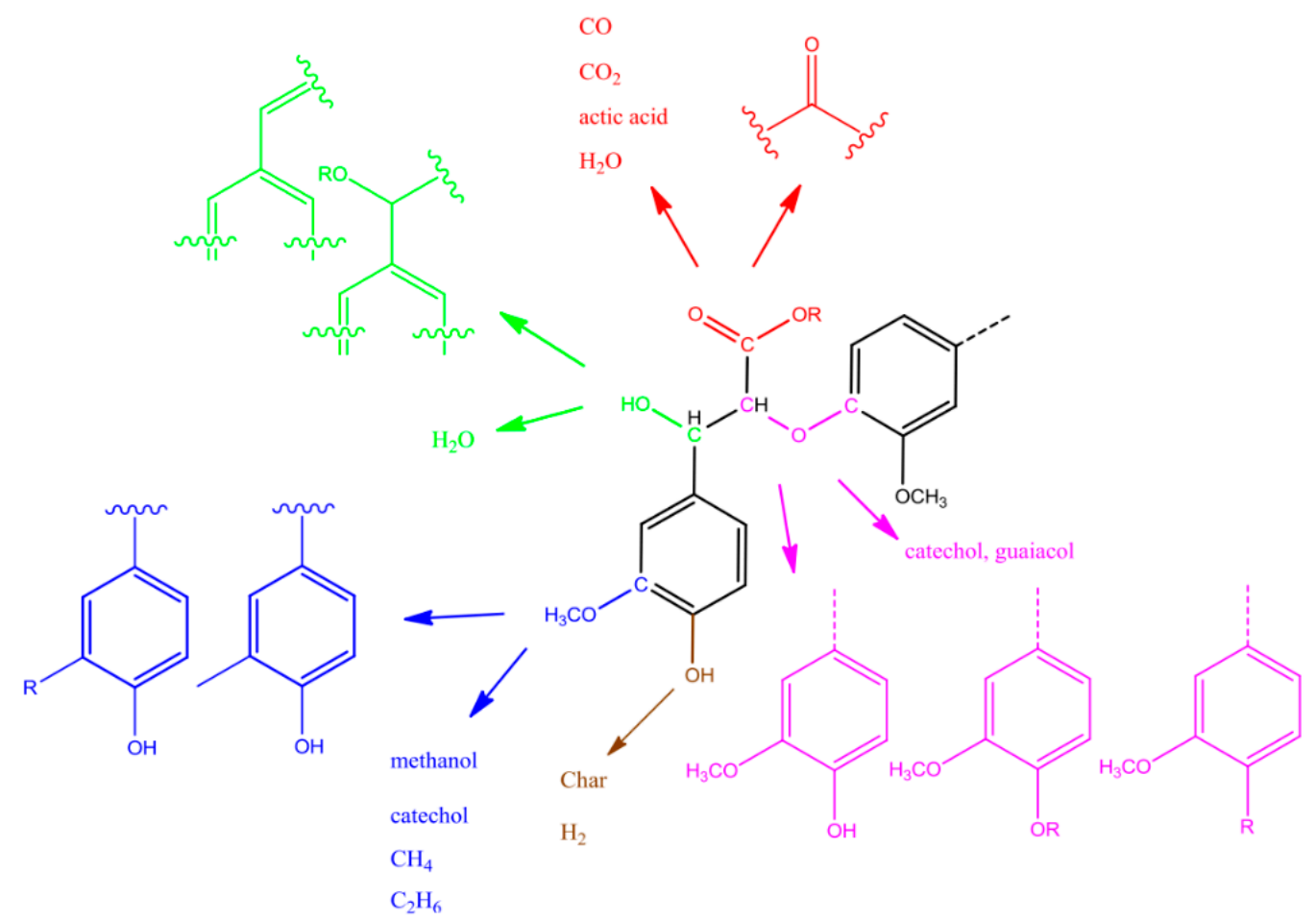

Figure 1. The possible decomposition pathways of lignin during the pyrolysis [8].

\subsection{Pyrolysis of Lignin to Oil over Ni-Based Catalysts}

Lignin pyrolysis oil derived from the traditional thermal decomposition of biomass is unstable due to the high oxygen content. Catalytic pyrolysis has been demonstrated as a highly efficient and environmental friendly technology to improve the quality of the bio-oil by coupling the catalytic cracking and deoxygenation of pyrolysis vapor phase to produce mono-phenolics or stable aromatic hydrocarbons from lignin, which reduces the oxygen content and enhances the quality for meeting the applications in both fuels and chemicals. Generally, catalysts that include metal sites (metal, metal oxides, or metal salts) play an important role in the catalytic pyrolysis of lignin. Recently, Ni-based catalysts have aroused widespread concern regarding the pyrolysis of lignin to oil, and these important findings are summarized in Table 1. Ben and Ragauskas studied the catalytic pyrolysis process of Kraft lignin over $\mathrm{NiCl}_{2}$ and $\mathrm{ZSM}-5$ zeolite and found that the additive could promote the decomposition of methoxy groups, carboxyl, and ether bonds, which decreased the oxygen content in the bio-oil [9]. Collard et al. investigated the pyrolysis of three main constituents of Beech wood over metallic Ni and $\mathrm{Fe}$. The aromatic rings in the matrix were rearranged over metal catalysts, while Ni was beneficial to the production of hydrogen [10]. Recently, it was found that adding formic acid in the form of metal salt to lignin before a fast pyrolysis process promoted the HDO of lignin, leading to the removal of methoxy groups and increase in the liquid yield, especially enhancing the carbon yield of the oil. Typically, nickel formate was thermally decomposed to form hydrogen in the catalytic pyrolysis process, which resulted in the HDO of alkali lignin during pyrolysis and significantly increased the yield of alkylphenols and aromatics, thus simplifying the complexity of alkali lignin pyrolysis products (as shown in Figure 2) [11]. 
Table 1. Pyrolysis of lignin to oil over Ni-based catalysts.

\begin{tabular}{|c|c|c|c|c|c|c|c|c|}
\hline \multirow{2}{*}{ Cat. } & \multicolumn{4}{|c|}{ Reaction Conditions } & \multirow{2}{*}{ Substrate } & \multirow{2}{*}{$\begin{array}{l}\text { Major Oil Products } \\
\text { yield/ (wt \%) }\end{array}$} & \multirow{2}{*}{ Reactor } & \multirow{2}{*}{ ref } \\
\hline & Loading(wt \%) & Temperature $\left({ }^{\circ} \mathrm{C}\right)$ & Time (min) & Atmosphere & & & & \\
\hline $\mathrm{NiCl}_{2}-\mathrm{ZSM}-5$ & 10 & 700 & 10 & $\mathrm{~N}_{2}$ & Kraft lignin & $\begin{array}{l}\text { heavy oil (34.5) } \\
\text { light oil (11.5) }\end{array}$ & $\begin{array}{l}\text { Quartz } \\
\text { pyrolysis tube }\end{array}$ & [9] \\
\hline $\begin{array}{l}\mathrm{Ni}\left(\mathrm{NO}_{3}\right)_{2} \cdot 6 \mathrm{H}_{2} \mathrm{O} \\
(\mathrm{W}-\mathrm{Ni} 0.1)\end{array}$ & - & 600 & 12 & $\mathrm{~N}_{2}$ & wood & $\begin{array}{l}\operatorname{tar}(38.4) \\
\text { water }(18.3)\end{array}$ & $\begin{array}{l}\text { Tubular } \\
\text { heatedreactor }\end{array}$ & [10] \\
\hline Nickel formate & - & 600 & $1.0 \mathrm{~s}$ & $\mathrm{~N}_{2}$ & alkali lignin & $\begin{array}{l}\text { phenols (59.19) } \\
\text { HCs (16.15) } \\
\text { alcohols (17.2) }\end{array}$ & $\begin{array}{l}\text { Fixed-bed } \\
\text { reactor }\end{array}$ & [11] \\
\hline Ni-HZSM-5 & 5 & 500 & 30 & $\mathrm{~N}_{2}$ & Pine wood & aromatic (41.3) & $\begin{array}{l}\text { Fixed-bed } \\
\text { reactor }\end{array}$ & [12] \\
\hline $\mathrm{NiO} / \mathrm{ZSM}-5$ & 34.8 & 500 & 15 & $\mathrm{~N}_{2}$ & Hardwood lignin & $\begin{array}{l}34.8 \text { with sel. to } \\
\text { phenol (68.7) } \\
\text { HC (12.2) }\end{array}$ & $\begin{array}{l}\text { Fixed-bed } \\
\text { reactor }\end{array}$ & [13] \\
\hline Ni-ZSM-5 & 5 & 450 & $<0.5 \mathrm{~s}$ & $\mathrm{~N}_{2}$ & hydrolysis lignin & $85 \mathrm{mg} / \mathrm{g}-\mathrm{HL}$ & $\begin{array}{l}\text { Drop-tube/fixed } \\
\text { bed reactor }\end{array}$ & [14] \\
\hline $\mathrm{Ni} / \mathrm{IS}$ & 1.8 & 900 & $1.9 \mathrm{~s}$ & $\mathrm{~N}_{2}$ & lignin & $\begin{array}{l}92.71 \% \text { conv. } \\
\text { with sel. to benzene } \\
(80.1)\end{array}$ & $\begin{array}{l}\text { Fixed-bed } \\
\text { quartz } \\
\text { tube reactor }\end{array}$ & [15] \\
\hline & & & & & soda pulping lignin & $\begin{array}{l}\text { phenol (18.0) } \\
\text { char (38.5) }\end{array}$ & & \\
\hline $\mathrm{Ni} / \mathrm{Al}$ & 1.0 & $30-600$ & $10^{\circ} \mathrm{C} / \mathrm{min}$ & $\mathrm{Ar}$ & $\begin{array}{l}\text { Soda-anthraquinone } \\
\text { pulping lignin } \\
\text { Enzymatic } \\
\text { hydrolysis lignin }\end{array}$ & $\begin{array}{l}\text { phenol (35.0) } \\
\text { char }(38.6) \\
\text { phenol }(4.0) \\
\text { char (37.9) }\end{array}$ & GA-TD-GC-MS & [16] \\
\hline Ni/DHZSM-5 & 5 & 600 & - & - & $\begin{array}{l}\text { Kraft lignin \& } \\
\text { refuse-derived fuels }\end{array}$ & aromatic hydrocarbon & $\begin{array}{l}\text { Conventional } \\
\text { Pyrolyzer }\end{array}$ & {$[17]$} \\
\hline Ni/HZSM-5 & 3 & 600 & - & $\begin{array}{l}\mathrm{CH}_{4} / \mathrm{He} \\
(100 \mathrm{ml} / \mathrm{min})\end{array}$ & Lignin + methane & $\begin{array}{l}\text { oil } 27.0 \text { with sel. to } \\
\text { total HCs (77) }\end{array}$ & $\begin{array}{l}\text { Horizontal } \\
\text { quartz reactor }\end{array}$ & [18] \\
\hline
\end{tabular}




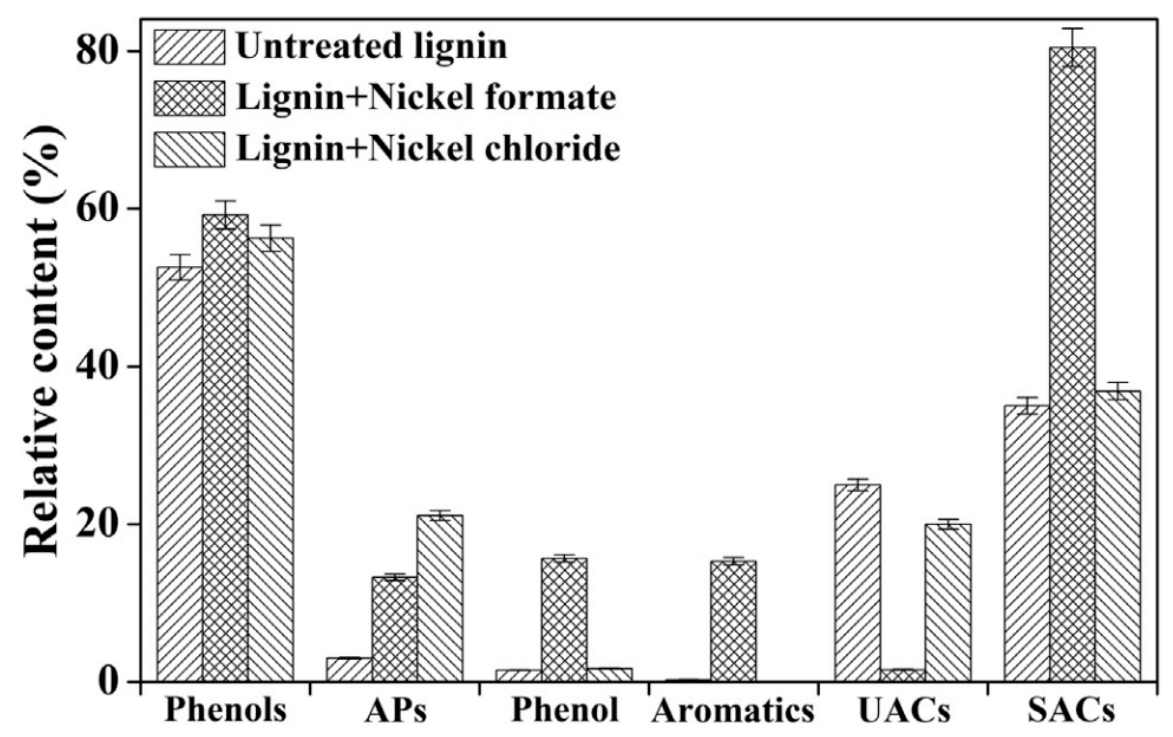

Figure 2. Effects of nickel salts on the characteristics of typical products paralyzed from alkali lignin at $600{ }^{\circ} \mathrm{C}$. APs: Alkylphenols; UACs: Unsaturated aromatic compounds; SACs: Saturated aromatic compounds [11].

Due to the good HDO properties of metal modified zeolite catalyst, the liquid yields were decreased over the M-ZSM- 5 catalysts in catalytic pyrolysis of lignin while that of the non-condensable gas was significantly increased. For example, the Ni-modified ZSM-5 catalysts could obviously improve the selectivity of benzene production and $\mathrm{C}^{+} 0^{+}$polycyclic aromatic hydrocarbons $(31.36 \%)$, which was much higher than those over other metals modified ZSM- 5 catalysts, as shown in Figure 3 [12]. The modification of $\mathrm{NiO}$ on ZSM- 5 changed the concentration and type of the acid sites of ZSM-5 support, and increased its specific surface area, subsequently improved the yield of bio-oil during fast pyrolysis of lignin [13]. Ni-loaded ZSM-5 catalyst also improved the yield of monomeric aromatics/phenolics from catalytic fast pyrolysis of hydrolyzed lignin (HL) containing ca. $60 \%$ lignin and other unreacted cellulose, mono and oligosaccharides, which were attributed to the increased Brønsted acid site and total acidity of the catalyst. A value of $85 \mathrm{mg} / \mathrm{g}$-HL oil products can be achieved for Ni-ZSM- 5 catalyst, which is much higher than that without catalyst (68 mg/g HL) [14]. Yu et al. analyzed the characteristics of the volatile matter during catalytic pyrolysis of biomass components (lignin, cellulose, and hemicellulose) on a novel Ni-based catalyst supported on iron slag (IS), which was close to the catalytic performance of the common alumina nickel catalysts [15]. The cheap and environmentally friendly Ni-based IS catalyst significantly improved the tar conversion of lignin (92.71\%) and inhibiting the coke deposition on the catalyst surface. For producing phenols from pyrolysis of lignin, Gorgens et al. screened 12 catalysts $\left(\mathrm{Al}_{2} \mathrm{O}_{3}, \mathrm{CaO}, \mathrm{Fe}_{2} \mathrm{O}_{3}, \mathrm{TiO}_{2}, \mathrm{ZnO}, \mathrm{MgO}, \mathrm{CuO}, \mathrm{MoO}_{3}, \mathrm{NiO}, \mathrm{Ni} / \mathrm{Al}_{2} \mathrm{O}_{3}-\mathrm{SiO}_{2}, \mathrm{NaOH}\right.$, and $\left.\mathrm{KOH}\right)$ for pyrolysis of sugarcane lignins at $1 \mathrm{wt} \%$ content [16]. The highest total yield of phenols was obtained with $\mathrm{KOH}$ for SD (soda pulping) lignin (+25.7\%), CaO for SAQ (soda-anthraquinone pulping) lignin $(+59.7 \%)$, and $\mathrm{Fe}_{2} \mathrm{O}_{3}$ for $\mathrm{SEH}$ (steam explosion pre-treatment followed by enzymatic hydrolysis) lignin $(+43.0 \%)$. Ni-based catalysts also promoted the yield of phenols, especially with $\mathrm{Ni} / \mathrm{Al}_{2} \mathrm{O}_{3}-\mathrm{SiO}_{2}$ for SAQ lignin (+34.5\%). Jiang et al. combined Raney $\mathrm{Ni}$ and acidic zeolite (USY) catalysts and achieved the depolymerization of cellulolytic enzyme lignin into phenolic monomers [19]. The yield of oil was over $60 \mathrm{wt} \%$, in which the yields of monophenols could reach to $27.9 \mathrm{wt} \%$.

In addition, the blending of hydrogen-rich materials, such as plastics, methane, to the catalytic pyrolysis process with lignin significantly improved the yield of value-added products (aromatic hydrocarbons). Synergistic effect was observed due to the balance between hydrogen and oxygen in the feedstock. Recently, Park et al. investigated the catalytic co-pyrolysis of Kraft lignin with refuse-derived fuels [17]. As shown in Figure 4, the yields of aromatic hydrocarbons was much higher than the theoretical value for all catalysts, which could be attributed to the synergistic effect of hydrogen rich 
feedstock co-feeding. Ni/desilicated HZSM-5 catalyst showed higher aromatic hydrocarbon formation than using HZSM-5 and HZSM-5 supported Ni catalysts owing to its higher acidity and mesoporosity. Besides, the distribution of products greatly depended on the atmosphere for the pyrolysis. When the pyrolysis atmosphere changed from nitrogen to methane, the yield of alkylphenols increased while the yields of both benzene, toluene, ethylbenzene, and xylene (BTEX) and aromatic HCs were remarkable decreased. It could be attributed to the fact that the competitive reaction occurred on the similar catalytic sites. Methane was activated and then oligomerized to olefins, which inhibited the degree of deoxygenation of lignin-derived phenolics to some extent. However, the yields of both BTEX and aromatic HCs were enhanced over metal-modified HZSM- 5 catalysts, which could be attributed to the synergistic effect of metal active sites and the enhanced acid property of zeolite, promoting both reactions of methane activation and phenolics deoxygenation. Specifically, $3 \mathrm{wt} \% \mathrm{Ni} / \mathrm{HZSM}-5$ catalyst could achieve the maximum increase in the yields of BTEX (by 13 times) and aromatic HCs (by 1.3 times), due to the enhancement of acid site density of catalyst and the excellent catalytic property of metallic Ni for methane activation [18].

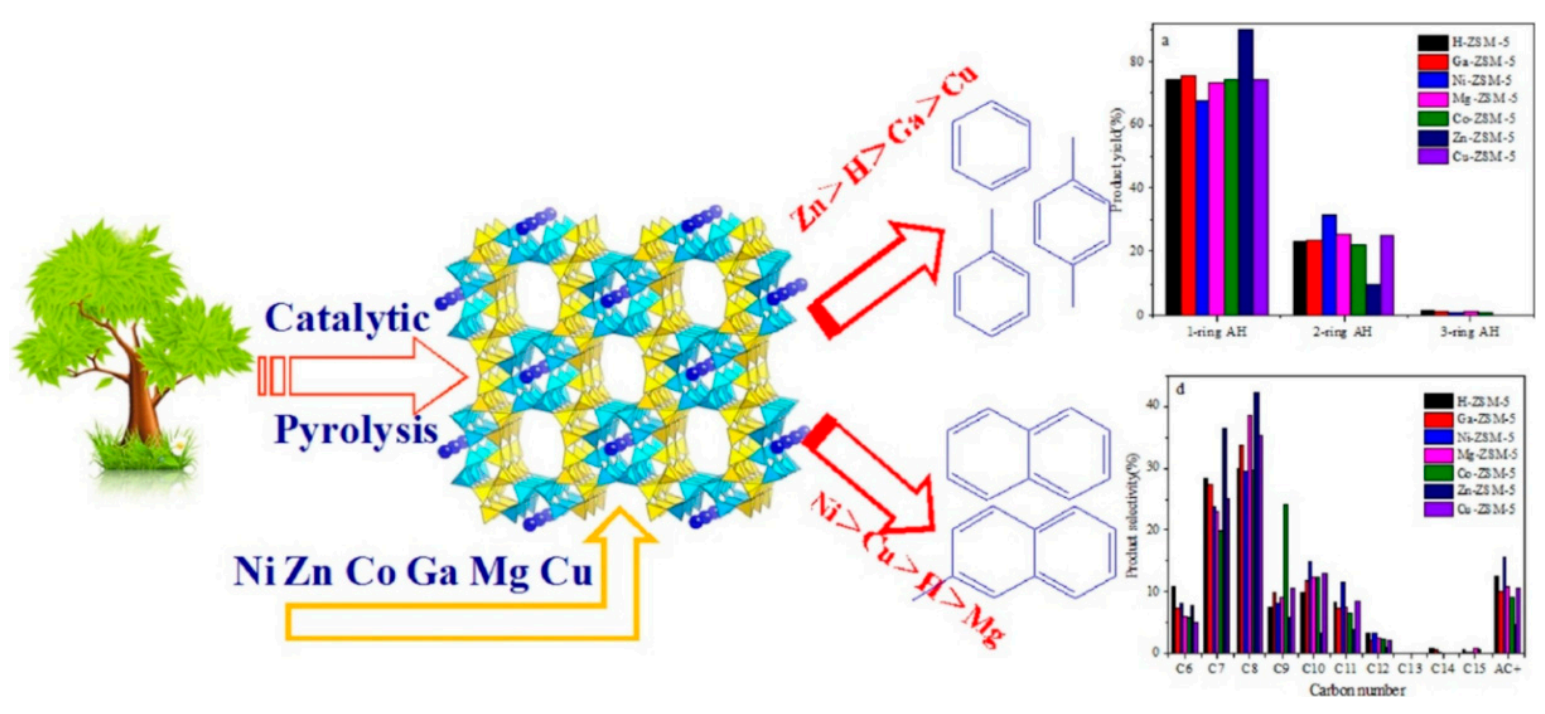

Figure 3. Metal-modified ZSM-5 for catalytic pyrolysis upgrading of biomass [12].

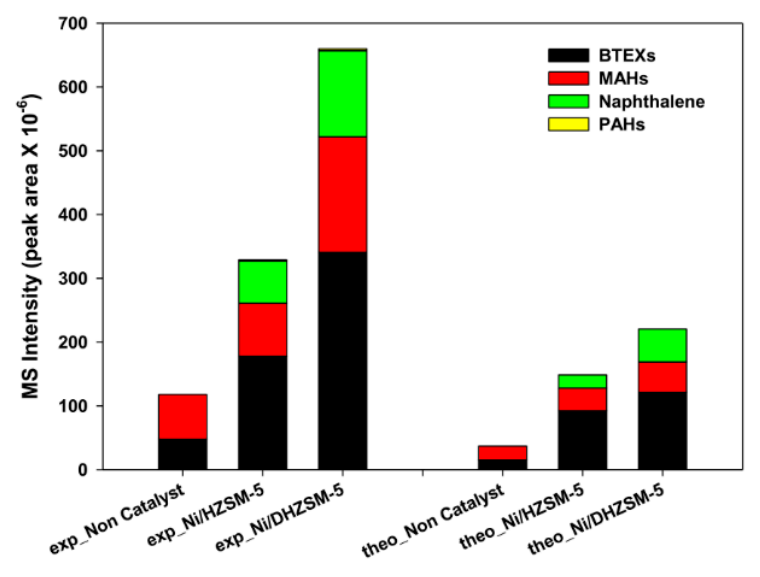

(a)

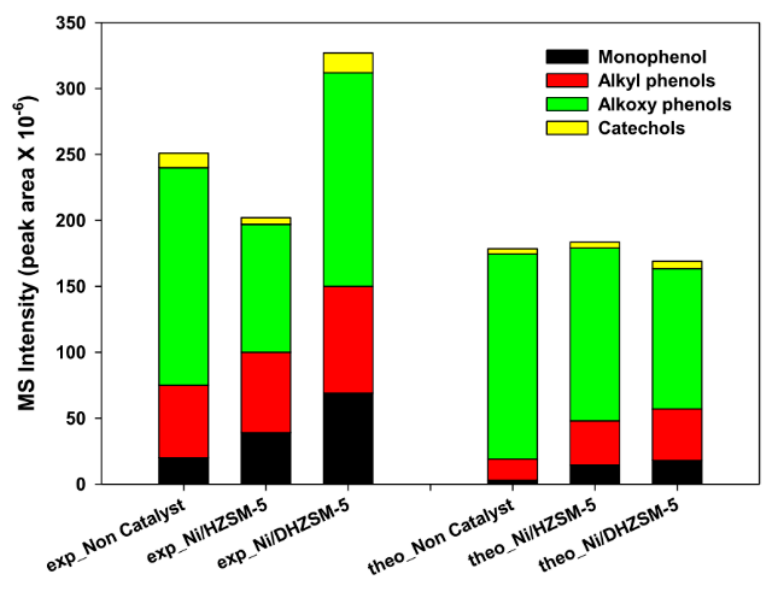

(b)

Figure 4. Comparison of experimental and theoretical value of (a) aromatic hydrocarbons and (b) phenolics from the catalytic co-pyrolysis of Kraft lignin and refuse-derived fuels over different catalysts [17]. 


\subsection{Pyrolysis of Lignin to Gas over Ni-Based Catalysts}

The pyrolysis/gasification of biomass has been confirmed to be an effective technology to produce syngas, which can be used for power generation systems or the synthesis of fine chemicals such as methanol and hydrocarbons employing the Fischer-Tropsch process. In particular, hydrogen derived from biomass has become an attractive strategy since it is a step towards economical viable hydrogen and sustainable supplies for it to be used as zero carbon emission fuel. In this regard, the catalyst plays an important role in boosting the yield of hydrogen production and reduction of tar from biomass gasification. Ni-based catalysts are low-cost, stable, effective materials could replace costly $\mathrm{Pt}$ in the production of hydrogen during the gasification of biomass. Table 2 summarized the typical conditions of the gasification of lignin to gas over Ni-based catalysts. Williams et al. investigated the pyrolysis/gasification of biomass components over various Ni-based catalysts by using a two-stage fixed-bed reaction system, including Ni-Ca-Al, Ni-Mg-Al, Ni-Zn-Al, Ni-Ca-Zn-Al catalysts [20,21]. Figure 5 showed the gas concentrations derived from pyrolysis/gasification of various biomass derived samples [20]. Compared with cellulose and xylan at $500{ }^{\circ} \mathrm{C}$, the pyrolysis/gasification of lignin was relatively difficult, which only produced $42.7 \mathrm{wt} \%$ gas but $56.0 \mathrm{wt} \%$ of residue fraction. However, the highest $\mathrm{H}_{2}$ concentration (55.1 vol \%) could be achieved with the steam reforming of lignin sample over catalyst. It was worth noting that $\mathrm{Ni}-\mathrm{Mg}-\mathrm{Al}$ catalyst could significantly eliminate the carbon deposition in this process [20]. Ni/CaO- $\mathrm{ZrO}_{2}$ catalyst also enhanced the hydrogen production for the steaming of biomass woodchips (pine, beech, and poplar). An incorporation of $\mathrm{Ca}$ into the structure of the $\mathrm{Ni} / \mathrm{ZrO}_{2}$ catalyst led to a decrease in the rate of coke formation on its surface, leading to enhanced stability of the catalyst [22].

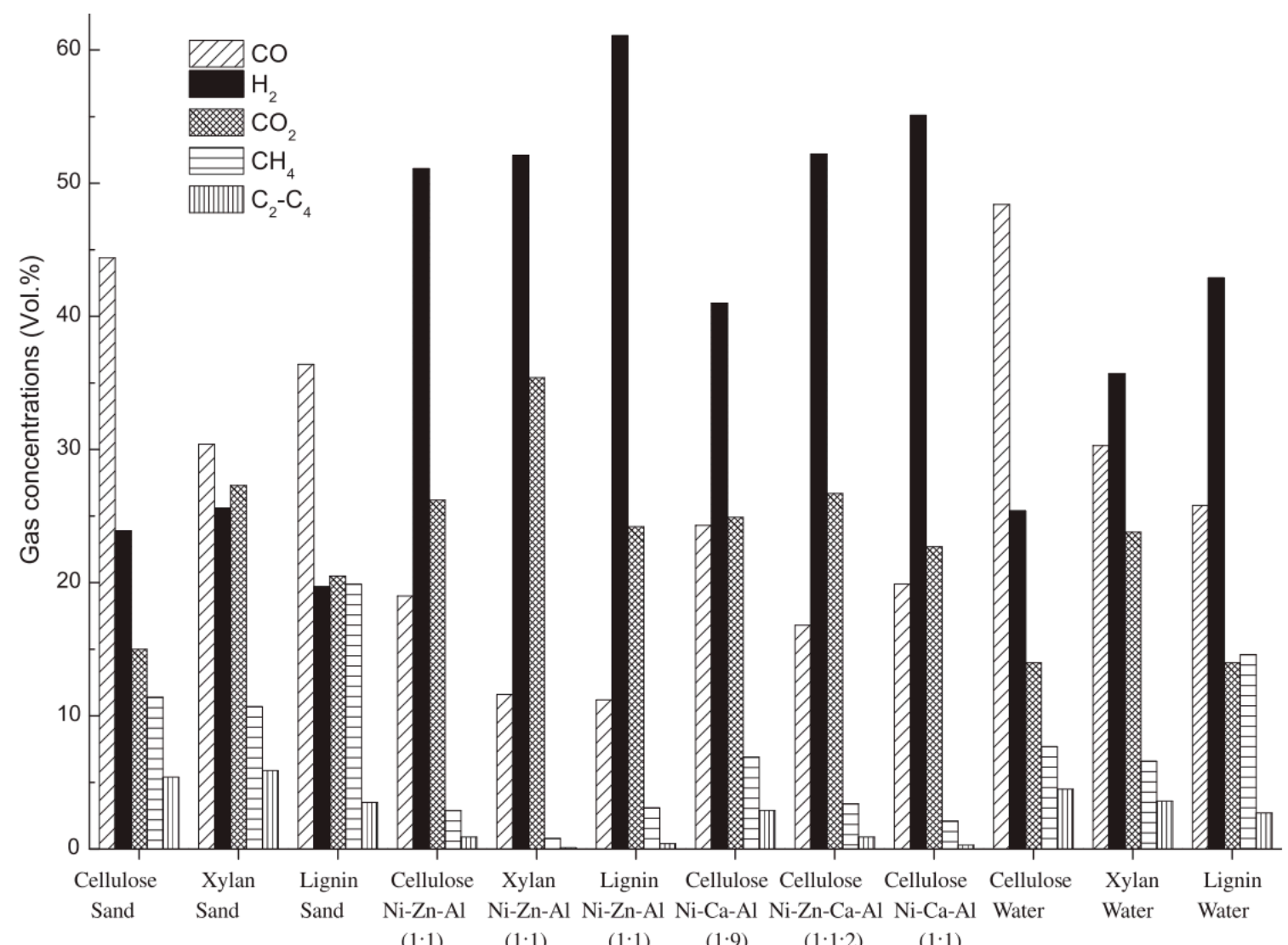

Figure 5. Gas concentrations from pyrolysis/gasification of various samples [20]. 
Table 2. Pyrolysis of lignin to gas over Ni-based catalysts.

\begin{tabular}{|c|c|c|c|c|c|c|c|c|}
\hline \multirow{2}{*}{ Cat. } & \multicolumn{4}{|c|}{ Reaction Conditions } & \multirow{2}{*}{ Substrate } & \multirow{2}{*}{$\begin{array}{c}\text { Gas Concentration/ } \\
\text { (vol \%) }\end{array}$} & \multirow{2}{*}{ Reactor } & \multirow{2}{*}{ Ref } \\
\hline & Loading (wt \%) & Temperature $\left({ }^{\circ} \mathrm{C}\right)$ & Steam $\left(\mathrm{g} \mathrm{min}^{-1}\right)$ & Atmosphere & & & & \\
\hline $\mathrm{Ni}-\mathrm{Mg}-\mathrm{Al}$ & $20 \mathrm{~mol} \%$ & 800 & $\mathrm{H}_{2} \mathrm{O}(0.05)$ & $\mathrm{N}_{2}\left(80 \mathrm{~mL} \mathrm{~min}^{-1}\right)$ & lignin & $\begin{array}{c}\text { gas yield (42.7) } \\
\mathrm{H}_{2}\left(14.0 \mathrm{mmol} \mathrm{g}^{-1}\right)\end{array}$ & $\begin{array}{c}\text { two-stage } \\
\text { reaction system }\end{array}$ & [20] \\
\hline $\mathrm{Ni}-\mathrm{Ca}-\mathrm{Al}$ & $20 \mathrm{~mol} \%$ & 900 & $\mathrm{H}_{2} \mathrm{O}(0.02)$ & $\mathrm{N}_{2}\left(80 \mathrm{~mL} \mathrm{~min}{ }^{-1}\right)$ & lignin & $\begin{array}{c}\text { gas yield }(48.0) \\
\mathrm{H}_{2}\left(17.8 \mathrm{mmol} \mathrm{g}^{-1}\right)\end{array}$ & $\begin{array}{l}\text { two-stage } \\
\text { reaction system }\end{array}$ & [20] \\
\hline $\mathrm{Ni}-\mathrm{Zn}-\mathrm{Al}$ & $20 \mathrm{~mol} \%$ & 800 & $\mathrm{H}_{2} \mathrm{O}(0.05)$ & $\mathrm{N}_{2}\left(80 \mathrm{~mL} \mathrm{~min}^{-1}\right)$ & lignin & $\begin{array}{c}\text { gas yield (50.0) } \\
\mathrm{H}_{2}\left(19.4 \mathrm{mmol} \mathrm{g}^{-1}\right)\end{array}$ & $\begin{array}{l}\text { Fixed-bed, } \\
\text { two-stage } \\
\text { reaction system }\end{array}$ & {$[21]$} \\
\hline $\mathrm{Ni} / \mathrm{CaO}-\mathrm{ZrO}_{2}$ & 20 & 700 & - & $\operatorname{Ar}\left(15 \mathrm{~mL} \mathrm{~min}{ }^{-1}\right)$ & $\begin{array}{l}\text { Pine A } \\
\text { Beech } \\
\text { Birch }\end{array}$ & $\begin{array}{c}\mathrm{H}_{2}\left(13.7 \mathrm{mmol} \mathrm{g}^{-1}\right) \\
\mathrm{H}_{2}\left(10.1 \mathrm{mmol} \mathrm{g}^{-1}\right) \\
\mathrm{H}_{2}\left(9.8 \mathrm{mmol} \mathrm{g}^{-1}\right)\end{array}$ & $\begin{array}{l}\text { Quartz fixed } \\
\text { bed two step } \\
\text { reactor }\end{array}$ & [22] \\
\hline $\mathrm{Ni} / \mathrm{MgO}$ & 10 & $\begin{array}{c}600 \\
(1.5 \mathrm{MPa})\end{array}$ & Reaction time (2 h) & $\operatorname{Ar}(\mathrm{SCW})$ & organosolv lignin & Carbon yield (30) & $\begin{array}{l}\text { Stainless steel } \\
\text { tube bomb } \\
\text { reactor }\end{array}$ & [23] \\
\hline $\mathrm{Ni} / \alpha-\mathrm{Al}_{2} \mathrm{O}_{3}$ & 10 & 700 & $01 \mathrm{mlmin}^{-1} \mathrm{~s} / \mathrm{C}-12$ & space time $0.22 \mathrm{~g}_{\text {cat. }} \mathrm{H}$ & bio-oil & Sel. $\mathrm{H}_{2}(63.5)$ & Fluidized bed & {$[24]$} \\
\hline $\mathrm{Ni} / \mathrm{La}_{2} \mathrm{O}_{3}-\alpha-\mathrm{Al}_{2} \mathrm{O}_{3}$ & 10 & & & $\left(\mathrm{~g}_{\text {bin-oil }}\right)^{-}$ & & $\begin{array}{l}\mathrm{H}_{2} \text { yield (96) } \\
\text { Sel. } \mathrm{H}_{2}(68.3)\end{array}$ & reactor & \\
\hline $\mathrm{Ni} / \mathrm{La}_{2} \mathrm{O}_{3}-\alpha-\mathrm{Al}_{2} \mathrm{O}_{3}$ & 10 & 600 & - & $\begin{array}{l}\text { space time } 0.45 \text { gcat. } \mathrm{H} \\
\left(\mathrm{g}_{\text {bio-oil }}\right)^{-1}\end{array}$ & $\begin{array}{l}\text { bio-oil with in situ } \\
\mathrm{CO}_{2} \text { capture }\end{array}$ & $\begin{array}{l}\text { full conversion } \\
\mathrm{H}_{2} \text { yield (99) }\end{array}$ & $\begin{array}{l}\text { Fluidized bed } \\
\text { reactor }\end{array}$ & [25] \\
\hline $\mathrm{Ni} / \mathrm{La}_{2} \mathrm{O}_{3}-\alpha-\mathrm{Al}_{2} \mathrm{O}_{3}$ & 10 & 700 & $S / C=6$ & $\begin{array}{l}\text { space time } 0.19 \mathrm{~g}_{\text {cat. }} \mathrm{H} \\
\left(\mathrm{g}_{\text {bio-oil }}\right)^{-1}\end{array}$ & $\begin{array}{l}\text { remaining } \\
\text { oxygenates in } \\
\text { bio-oil }\end{array}$ & $\begin{array}{l}\text { Conv. (100) } \\
\mathrm{H}_{2} \text { yield (95) }\end{array}$ & $\begin{array}{l}\text { Fluidized bed } \\
\text { reactor }\end{array}$ & {$[26,27]$} \\
\hline $\mathrm{Ni} / \mathrm{La}_{2} \mathrm{O}_{3}-\alpha-\mathrm{Al}_{2} \mathrm{O}_{3}$ & 10 & 700 & $\begin{array}{c}\text { Time on stream }(1 \mathrm{~h}) \\
S / C=6 \\
O / C=0.67\end{array}$ & $\begin{array}{l}\text { space time } 0.3 g_{\text {cat. }} \mathrm{H} \\
\qquad\left(\mathrm{g}_{\text {bio-oil }}\right)^{-1}\end{array}$ & raw bio-oil & $\begin{array}{c}\mathrm{X}_{\text {bio-oil }}(100) \\
\mathrm{H}_{2} \text { yield (58) }\end{array}$ & $\begin{array}{l}\text { Fluidized bed } \\
\text { reactor }\end{array}$ & [28] \\
\hline $\mathrm{Ni} / \alpha-\mathrm{Al}_{2} \mathrm{O}_{3}$ & 10 & 700 & $\mathrm{~S} / \mathrm{C}=10$ & $\begin{array}{c}\text { space time } 0.23 \mathrm{~g}_{\text {cat. }} \mathrm{H} \\
\left(\mathrm{g}_{\text {bio-oil }}\right)^{-1}\end{array}$ & $\begin{array}{l}\text { bio-oil/bio-ethanol } \\
\text { (50 wt \% of ethanol) }\end{array}$ & $\begin{array}{c}\mathrm{X}_{\text {oxygenates }}(100) \\
\mathrm{H}_{2} \text { yield (93) }\end{array}$ & $\begin{array}{l}\text { Fluidized bed } \\
\text { reactor }\end{array}$ & [29] \\
\hline $\mathrm{Ni} / \mathrm{La}_{2} \mathrm{O}_{3}-\alpha-\mathrm{Al}_{2} \mathrm{O}_{3}$ & 10 & 700 & $\begin{array}{l}\text { Time on stream } \\
(100 \mathrm{~min}) \mathrm{S} / \mathrm{C}=6\end{array}$ & $\begin{array}{l}\text { space time } 0.27 \mathrm{~g}_{\text {cat. }} \mathrm{H} \\
\left(\mathrm{g}_{\text {bio-oil }}\right)^{-1}\end{array}$ & $\begin{array}{l}\text { bio-oil/bio-ethanol } \\
\text { (20 wt \% of ethanol) }\end{array}$ & $\begin{array}{c}\mathrm{X}_{\text {oxygenates }}(100) \\
\mathrm{H}_{2} \text { yield (94) }\end{array}$ & $\begin{array}{l}\text { Fluidized bed } \\
\text { reactor }\end{array}$ & [30] \\
\hline
\end{tabular}


Supercritical water (SCW) with low-viscosity, high-diffusivity values, and relatively high heat capacity promotes the solubility of lignin in water, improving the mass transfer efficiency of lignin and water over the catalyst. Furusawa et al. investigated the gasification of lignin in SCW using a stainless steel tube bomb reactor and found that $10 \mathrm{wt} \% \mathrm{Ni} / \mathrm{MgO}$ (calcined at $600{ }^{\circ} \mathrm{C}$ ) catalyst with an optimal $\mathrm{Ni}$ particle size exhibited the best catalytic performance (carbon yield 30\%) [23]. It was concluded that SCW gasification is an environmentally friendly, cost-effective manner for transforming biomass into hydrogen, which can potentially be used as a clean energy source.

Bio-oil derived from the anaerobic distillation of biomass produced a complex mixture of different oxygenated compounds with a high water content (ca. 21-27 wt \%), which cannot be used to substitute diesel in internal-combustion engines due to high viscosity and acidity. Steam reforming is thus a promising technology to valorization of the bio-oil because it avoids the costly separation of water to produce the clean energy source (hydrogen). The overall steam reforming of bio-oil is as follows:

$$
\mathrm{C}_{n} \mathrm{H}_{m} \mathrm{O}_{k}+(2 n-k) \mathrm{H}_{2} \mathrm{O} \rightarrow n \mathrm{CO}_{2}+\left(2 n+\frac{m}{2}-k\right) \mathrm{H}_{2}
$$

However, secondary reactions, including cracking, methane reforming, and Boudouard reaction were also observed in this process. Therefore, for a good balance concerning activity, stability, and cost, it is still a challenge to design a highly efficient catalyst for the steam reforming of bio-pyrolysis oil.

Valle et al. compared the catalytic properties of $\mathrm{Ni} / \alpha-\mathrm{Al}_{2} \mathrm{O}_{3}$ and $\mathrm{Ni} / \mathrm{La}_{2} \mathrm{O}_{3}-\alpha-\mathrm{Al}_{2} \mathrm{O}_{3}$ for steam reforming of bio-oil aqueous fraction by varying the pyrolytic lignin retention. Through investigation of reforming temperature and space time, it was found that $\mathrm{La}_{2} \mathrm{O}_{3}$ addition to the $\mathrm{Ni} / \alpha-\mathrm{Al}_{2} \mathrm{O}_{3}$ catalyst achieved the complete conversion of bio-oil at $700{ }^{\circ} \mathrm{C}$ and inhibited the deactivation of catalyst due to the high water adsorption capacity. At space-time of $0.22 \mathrm{~g}_{\text {catal. }} \mathrm{h}\left(\mathrm{g}_{\text {bio-oil }}\right)^{-1}$, the yield of hydrogen could reach $96 \%$ [24]. Remiro et al. studied the influence of $\mathrm{CO}_{2}$ capture during the hydrogen production by steam reforming of bio-oil aqueous fraction over a Ni/La $\mathrm{O}_{3}-\alpha-\mathrm{Al}_{2} \mathrm{O}_{3}$ catalyst in a fluidized bed reactor [25]. At $600{ }^{\circ} \mathrm{C}$ and a space-time of $0.45 \mathrm{~g}_{\text {catal. }} \mathrm{h}$ (g $\left.\mathrm{g}_{\text {bio-oil }}\right)^{-1}$, a suitable ratio of catalyst/dolomite (mass ratios $\geq 0.17$ ) which was stricken between the reforming and water gas shift (WGS) reactions, and the cracking and coke formation reactions, promoted the complete conversion of the bio-oil and ca. $99 \% \mathrm{H}_{2}$ was achieved while $95 \% \mathrm{CO}_{2}$ was captured. However, the stability of catalyst should be enhanced because some bio-oil compounds were found to re-polymerize at a high temperature, leading to the deposition of the formed carbonaceous solid on the catalyst [26]. To prevent the pyrolytic lignin deposition, an attempt has been made to separate the pyrolytic lignin and then catalytic steam reform the raw bio-oil over $\mathrm{Ni} / \mathrm{La}_{2} \mathrm{O}_{3}-\alpha-\mathrm{Al}_{2} \mathrm{O}_{3}$ catalyst in a fluidized bed reactor. At $700{ }^{\circ} \mathrm{C}$, the molar ratio of stem/carbon 9 , and space velocity $8000 \mathrm{~h}^{-1}$, the yields of $\mathrm{H}_{2}$ and $\mathrm{CO}$ reached at $95 \%$ and $6 \%$, respectively. Interestingly, the deactivation of $\mathrm{Ni} / \mathrm{La}_{2} \mathrm{O}_{3}-\alpha-\mathrm{Al}_{2} \mathrm{O}_{3}$ catalyst was significantly slowed down, whereby the $\mathrm{H}_{2}$ yield was almost unchanged over a duration of $100 \mathrm{~min}$ [27].

It was universally known that steam reforming reaction is an endothermic reaction, which requires the input of energy into the reaction system so that it is generally preferable for industrial design and implementation. However, the autothermal reforming regime can be achieved by oxidative steam reforming (OSR) with co-feeding $\mathrm{O}_{2}$ and the bio-oil. The OSR reaction for bio-oil is as follows:

$$
\mathrm{C}_{n} \mathrm{H}_{m} \mathrm{O}_{k}+p \mathrm{O}_{2}+(2 n-k-2 p) \mathrm{H}_{2} \mathrm{O} \rightarrow n \mathrm{CO}_{2}+\left(2 n+\frac{m}{2}-k-2 p\right) \mathrm{H}_{2}
$$

Remiro et al. tested the effect of $\mathrm{O}_{2}$ content in the OSR of raw bio-oil over two catalysts $\left(\mathrm{Ni} / \mathrm{La}_{2} \mathrm{O}_{3}-\alpha-\mathrm{Al}_{2} \mathrm{O}_{3}\right.$ and $\mathrm{Rh} / \mathrm{CeO}_{2}-\mathrm{ZrO}_{2}$ ) [28]. The results showed that the $\mathrm{Rh} / \mathrm{CeO}_{2}-\mathrm{ZrO}_{2}$ catalyst exhibited much higher activity than that over $\mathrm{Ni} / \mathrm{La}_{2} \mathrm{O}_{3}-\alpha-\mathrm{Al}_{2} \mathrm{O}_{3}$ catalyst. The addition of $\mathrm{O}_{2}$ into bio-oil significantly decreased the coke content. However, the deactivation of catalyst was not mitigated noticeably due to the sintering of the metal active sites. Therefore, development of a catalyst with high efficiency and stability is of vital importance for the OSR of raw bio-oil to produce hydrogen. 
In addition, Ni-based catalysts have been widely used for reforming mixtures of bio-oil and bio-ethanol to produce hydrogen in continuous thermal-catalytic process (as shown in Figure 6) [29]. Gayubo et al. reported that the steam reforming of the bio-oil aqueous fraction had been enhanced through the addition of bio-ethanol. The pyrolytic lignin deposition slightly attenuated, which inhibited the carbon deposition on the surface of catalyst, resulting in prolonged life of the catalyst [29]. Almost full conversion of the oxygenates was achieved and a high $\mathrm{H}_{2}$ yield $(>93 \%)$ can be reached over $\mathrm{Ni} / \alpha-\mathrm{Al}_{2} \mathrm{O}_{3}$ catalyst at the operating conditions of $700{ }^{\circ} \mathrm{C}$ and at space-time of $0.23 \mathrm{~g}$ catal. $\mathrm{h}\left(\mathrm{g}_{\text {bio-oil }+\mathrm{EtOH}}\right)^{-1}$ during the reforming the bio-oil/bio-ethanol mixtures $(50 \mathrm{wt} \%)$. The spent catalyst can be fully recovered at $700{ }^{\circ} \mathrm{C}$ after being regenerated by coke combustion. In addition, it was found that the amount and nature of the active metal dispersed on the support greatly depended on the preparation conditions (both the calcination and reduction temperatures), and it was found that they played an important role on the activity and stability of the catalyst in the reforming the mixtures of bio-oil and bio-ethanol. Among the tested catalysts prepared at various calcination and reduction temperatures, NiLa550-700 (calcined at $550{ }^{\circ} \mathrm{C}$, reduced at $700{ }^{\circ} \mathrm{C}$ ) catalyst achieved the highest conversion of bio-oil and hydrogen yield (94\%), indicating the lowest level of deactivation exhibited by the catalyst [30]. The catalytic reforming of bio-oil has aroused widespread interests, enhancing the stability of catalyst and avoiding the sintering and carbon deposition of catalysts still poses a great challenge to the researchers.

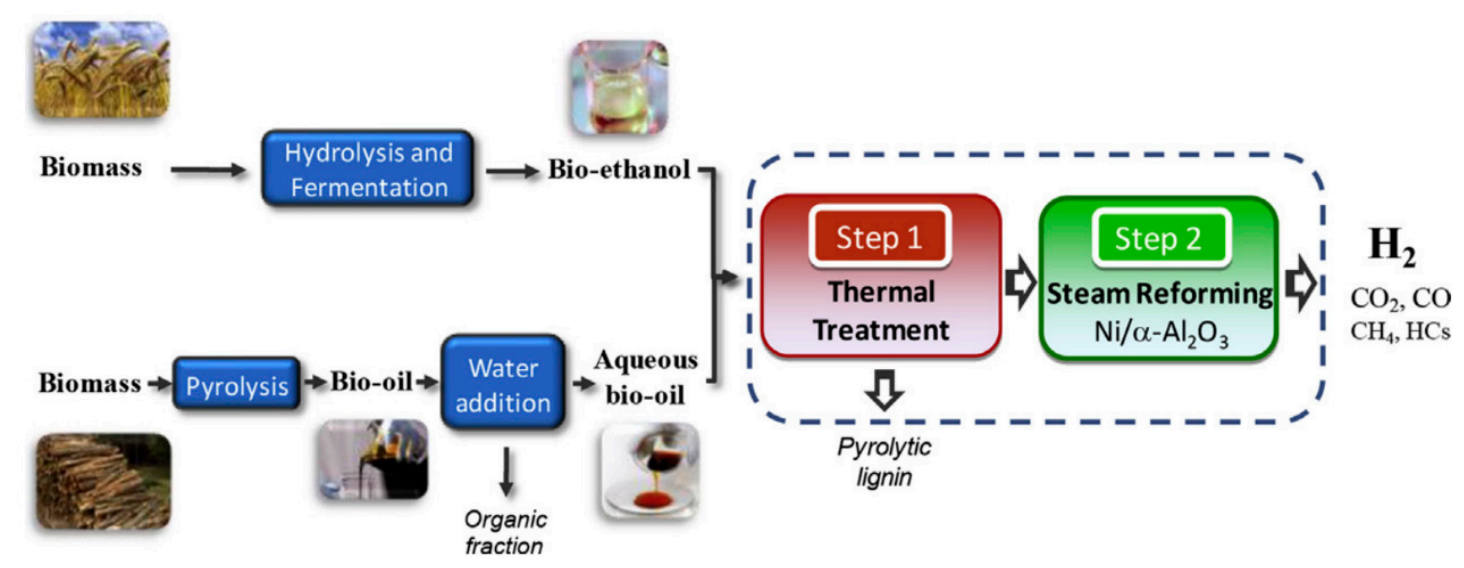

Figure 6. Hydrogen production layout according to the joint steam reforming of bio-oil and bio-ethanol obtained from biomass [29].

\section{Hydrodeoxygenation}

Hydrodeoxygenation (HDO) is regarded as an extremely promising efficient technology for the removal of oxygen and transformation of lignin and lignin-derived bio-oils into clean oxygen-free hydrocarbon fuels with a high conversion and low emission [31]. Nevertheless, in order to make this process feasible, highly efficient catalysts with low cost and good stability are urgently needed.

There is no doubt that precious metal-based catalysts, including palladium, platinum, rhodium, ruthenium, and gold, exhibit high efficient catalytic activity in the HDO of lignin [31]. However, the low earth-abundance and high costs limited the application of noble metal catalysts in the upgrading of lignin on commercial scales. With numerous successful examples on the special catalytic properties of Ni-based catalysts on the HDO of lignin, it is best to summarize the trends and mechanism of how Ni-based catalysts interact with oxygenated lignin molecules so that more efficient catalysts can be discovered in future. Basing on the Density Functional Theory (DFT) study results, the adsorption behavior of the represented the $\beta-\mathrm{O}-4$ dimer (guaiacylglycerol-beta-guaiacyl ether) on typical metal catalysts has been calculated since it contains the typical functional groups of an actual lignin polymer and also allows the possibility to study the effect of lignin side chain chirality. It was found that the $\beta-\mathrm{O}-4$ dimer preferred to be adsorbed strongly on $\mathrm{Ni}(111)$ surface and weakly on $\mathrm{Cu}(111)$ surface in 
vacuum medium, with both aryl rings being adsorbed on the surface [32]. However, dimer preferred to bind on $\mathrm{Ni}(111)$ and would not adsorb at all on $\mathrm{Cu}(111)$ surface in ethanol medium. Therefore, monometallic $\mathrm{Ni}$ and modified Ni-based catalysts are unique and promising catalysts for HDO of lignin-derived model compounds.

\subsection{Monometallic Ni-Based Catalysts for HDO of Lignin}

Owing to the complex macromolecular structure of lignin, most researchers drew their attention first to catalytic HDO of lignin model compounds [33-39] in order to help understand the catalytic behavior. As shown in Figure 7, lignin monomer model compounds such as phenol, anisole, guaiacol etc. and C-O-C linkage dimers such as 2-phenoxy-1-phenylethanol ( $\beta-\mathrm{O}-4$ linkage $\mathrm{C}-\mathrm{O}$ ether bond), diphenyl ether (4-O-5 linkage $\mathrm{C}-\mathrm{O}$ ether bond) and benzyl phenyl ether ( $\alpha-\mathrm{O}-4$ linkage $\mathrm{C}-\mathrm{O}$ ether bond) etc., had been broadly investigated using Ni-based catalysts in HDO reaction [33,34,36,37,40-42]. The HDO of representative lignin model compounds over monometallic nickel-based catalysts are listed in Table 3. Generally, harsh reaction conditions including high reaction temperature and $\mathrm{H}_{2}$ pressure $\left(>200^{\circ} \mathrm{C},>3.0 \mathrm{MPa}\right)$ were required to both cleavage of $\mathrm{C}$-O bonds and complete hydrogenation aromatic ring.
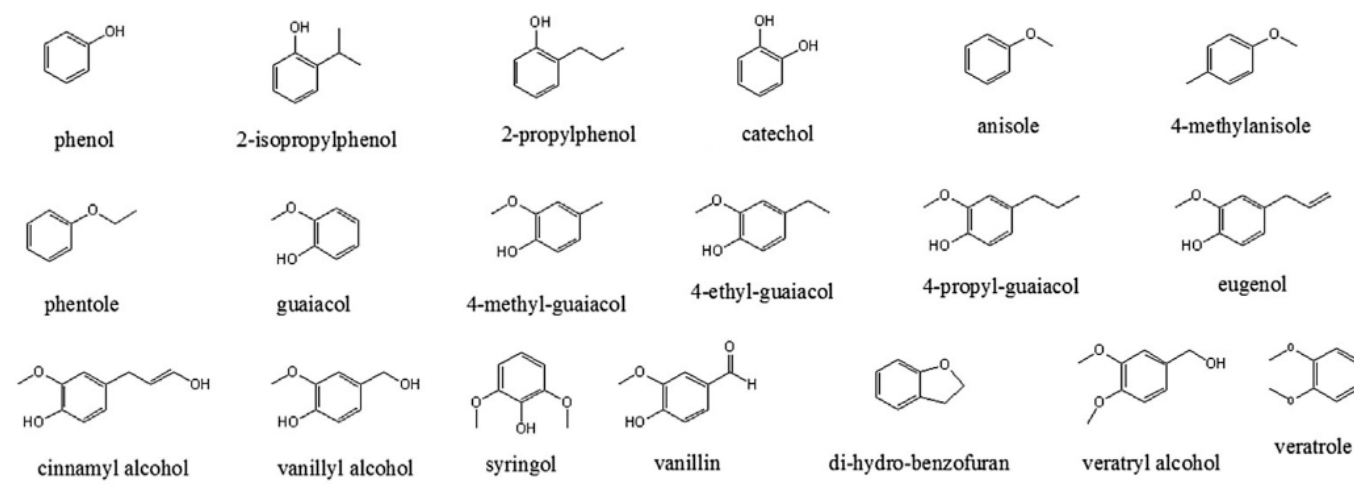

4-methyl-guaiacol
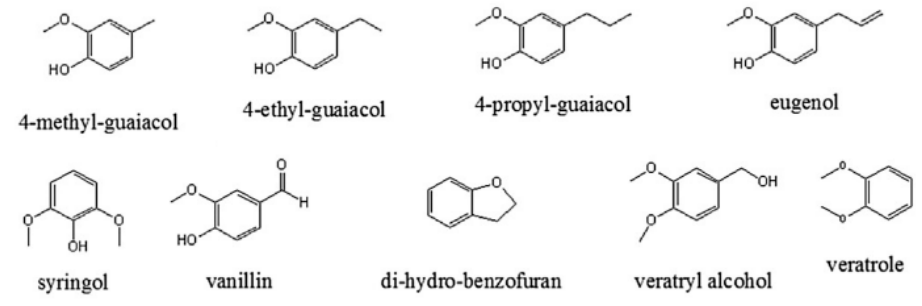

(a)

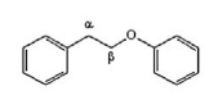

phenethyl-phenyl-ether

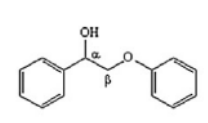

2-phenoxy-1phenethanol
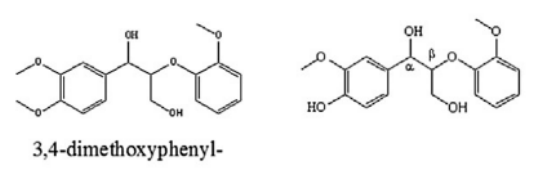

glycerol- $\beta$-guaiacyl-ether
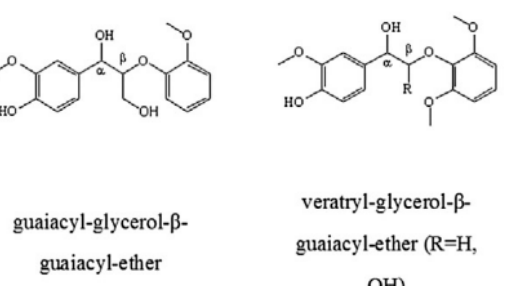
veratryl-glycerol- $\beta$ - guaiacyl-ether $(\mathrm{R}=\mathrm{H}$,

$\mathrm{OH})$

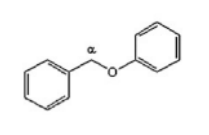

benzyl-phenyl-ether
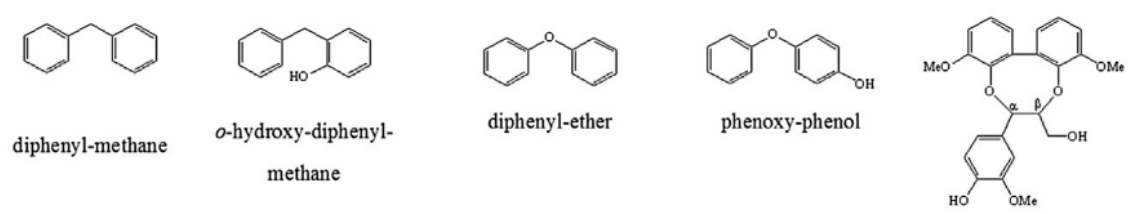

(b)

Figure 7. Lignin model compounds of monomers (a) and dimers (b) form ref [43]. 
Table 3. Hydrodeoxygenation (HDO) of lignin model compounds over monometallic Ni-based catalysts.

\begin{tabular}{|c|c|c|c|c|c|c|c|c|c|c|}
\hline \multirow{2}{*}{ Cat. } & \multicolumn{5}{|c|}{ Reaction Conditions } & \multirow{2}{*}{ Substrate } & \multirow{2}{*}{ Major products } & \multirow{2}{*}{ Conv. $(\%)$} & \multirow{2}{*}{ Reactor } & \multirow{2}{*}{ Ref } \\
\hline & Ni Loading (wt \%) & Support & $\mathrm{T}\left({ }^{\circ} \mathrm{C}\right)$ & P (MPa) & Solvent & & & & & \\
\hline $\mathrm{Ni}$ & 5 & Al-SBA-15 & 200 & 5.0 & methylcyclohexane & $\begin{array}{l}\text { diphenyl } \\
\text { ether }\end{array}$ & cyclohexane & 100 & Batch & [33] \\
\hline $\mathrm{Ni}$ & 10 & $\mathrm{SiO}_{2}$ & 220 & 3.0 & n-decane & anisole & cyclohexane & 100 & Batch & [34] \\
\hline $\mathrm{Ni}$ & 30 & $\mathrm{Nb}_{2} \mathrm{O}_{5} / \mathrm{AC}$ & 200 & 3.0 & n-decane & $\begin{array}{l}\text { diphenyl } \\
\text { ether }\end{array}$ & cyclohexane & $\sim 90$ & Fixed-bed & [35] \\
\hline Ni-W-B & - & - & 250 & 4.0 & dodecane & phenol & $\begin{array}{l}\text { cyclohexanone, } \\
\text { cyclohexane }\end{array}$ & 100 & Batch & [36] \\
\hline $\mathrm{Ni}$ & 95.65 & - & 230 & - & $\mathrm{i}-\mathrm{PrOH}$ & benzyl phenyl ether & phenol and toluene & 24 & Microwave & [37] \\
\hline $\mathrm{Ni}$ & 5 & Al-SBA-15 & 220 & 5.0 & decalin & anisole & cyclohexane & 99.8 & Batch & [38] \\
\hline Raney Ni & - & Nafion/ $/ \mathrm{SiO}_{2}$ & 300 & 4.0 & $\mathrm{H}_{2} \mathrm{O}$ & $\begin{array}{l}\text { 2-methoxy-4-n- } \\
\text { propylphenol }\end{array}$ & cyclohexanes & 80 & Batch & [39] \\
\hline $\mathrm{Ni}$ & 15 & CNTs & 300 & 5.0 & n-dodecane & guaiacol & cyclohexane & 100 & Batch & [44] \\
\hline $\mathrm{Ni}$ & 10 & $\mathrm{Al}_{2} \mathrm{O}_{3}$ & 300 & 5.0 & n-octane & phenol & cyclohexane & $>90$ & Batch & [45] \\
\hline $\mathrm{Ni}$ & 10 & $\mathrm{SiO}_{2}$ & 300 & 5.0 & n-octane & phenol & cyclohexane & 99.1 & Batch & [45] \\
\hline $\mathrm{Ni}$ & 10 & $\mathrm{ZnO}-\mathrm{Al}_{2} \mathrm{O}_{3}$ & 250 & 2.0 & n-hexane & $\begin{array}{l}\text { 2-phenoxy-1- } \\
\text { phenylethanone }\end{array}$ & ethylcyclohexane & 100 & Batch & [42] \\
\hline $\mathrm{Ni}$ & 7.41 & NCB-900 & 150 & 0.5 & $\mathrm{H}_{2} \mathrm{O}$ & vanillin & $\begin{array}{l}\text { 2-methoxy-4- } \\
\text { methylphenol }\end{array}$ & 74.4 & Batch & [31] \\
\hline $\mathrm{Ni}$ & 14.3 & HZSM-5 & 250 & 5.0 & dodecane & guaiacol & cyclohexane & 100 & Batch & [46] \\
\hline $\mathrm{Ni}$ & 14.3 & HZSM-5 & 250 & 5.0 & $0.1 \mathrm{M} \mathrm{NaOH}$ solution & $\begin{array}{l}\text { 2-phenoxy-1- } \\
\text { phenylethanol }\end{array}$ & ethylbenzene & 100 & Batch & [46] \\
\hline $\mathrm{Ni}$ & 20.2 & HZSM-5 & 250 & 5.0 & $\mathrm{H}_{2} \mathrm{O}$ & benzyl phenyl ether & $\begin{array}{l}\text { cyclohexane, } \\
\text { methylcyclohexane }\end{array}$ & 100 & Batch & [47] \\
\hline $\mathrm{Ni}$ & 20 & $\mathrm{SiO}_{2}-\mathrm{Al}_{2} \mathrm{O}_{3}$ & 200 & 2.0 & decalin & syringol & cyclohexane & 98.4 & Batch & [48] \\
\hline $\mathrm{Ni}$ & 10 & Al-MCM-41 & 400 & 0.1 & guaiacol & guaiacol & phenol & $>90$ & Fixed-bed & [49] \\
\hline $\mathrm{Ni}$ & 20 & $\mathrm{MgO}$ & 160 & 3.0 & decahydronaphthalene & guaiacol & cyclohexanol & 97.7 & Batch & [50] \\
\hline $\mathrm{Ni}$ & 15 & CNTs & 300 & 5.0 & n-dodecane & guaiacol & cyclohexanol & 100 & Batch & [51] \\
\hline $\mathrm{Ni}$ & 20 & $\mathrm{Al}_{2} \mathrm{O}_{3}$ & 290 & 0.3 & heptane & anisole & cyclohexane & 98 & Fixed-bed & [52] \\
\hline $\mathrm{Ni}$ & 20 & $\mathrm{TiO} 2$ & 290 & 0.3 & heptane & anisole & cyclohexane & 47 & Fixed-bed & [52] \\
\hline $\mathrm{Ni}$ & 10 & $\mathrm{ZrNbPO} 4$ & 220 & 0.5 & n-dodecane & diphenyl ether & $\begin{array}{l}\text { benzene \& } \\
\text { cyclohexane }\end{array}$ & 83.7 & Batch & [53] \\
\hline $\mathrm{Ni}_{2} \mathrm{P}$ & 5 & HZSM-5 & 200 & 2.5 & n-dodecane & m-cresol & methylcyclohexane & 91 & Batch & [54] \\
\hline $\mathrm{Ni}_{2} \mathrm{P}$ & 30 & $\mathrm{C}$ & 300 & 3.0 & n-dodecane & guaiacol & $\begin{array}{l}\text { cyclohexane, } \\
\text { methanol }\end{array}$ & $\begin{array}{l}4.18 \times 10^{-6} \\
\mathrm{~mol} \mathrm{~g}_{\text {cat }}-1 \mathrm{~s}^{-1}\end{array}$ & Batch & [55] \\
\hline $\mathrm{Ni}_{2} \mathrm{P}$ & 10 & $\mathrm{SiO}_{2}$ & 340 & 4.0 & n-dodecane & cresols & methylcyclohexane & $\sim 20$ & Fixed-bed & [56] \\
\hline $\mathrm{Ni}_{2} \mathrm{P}$ & 5.6 & $\mathrm{SiO}_{2}$ & 350 & 0.1 & - & Guaiacol & benzene & 98 & Fixed-bed & [57] \\
\hline
\end{tabular}


Anisole, as one representative of the methoxyphenyl family, was extensively investigated over Ni-based catalysts by various researchers, which may help understand the mechanism of de-alkylation and de-alkoxylation of the functional group [34,38,52]. Yang et al. developed a series of Ni-based catalysts including Ni/SBA-15, Ni/Al-SBA-15, Ni/ $\mathrm{Al}_{2} \mathrm{O}_{3}, \mathrm{Ni} / \mathrm{C}, \mathrm{Ni} / \mathrm{TiO}_{2}$ and $\mathrm{Ni} / \mathrm{CeO}_{2}$ for the $\mathrm{HDO}$ of anisole to investigate the influence of metal-support interactions [52], the reaction routes was depicted in Figure 8. The strong acidity of the support contributed to the cleavage of C-O bond in anisole while metallic sites further hydrogenated the reaction intermediates to form cyclohexane. Hence, dispersion of metal sites and acidity of support strongly influences the conversion and products selectivities.

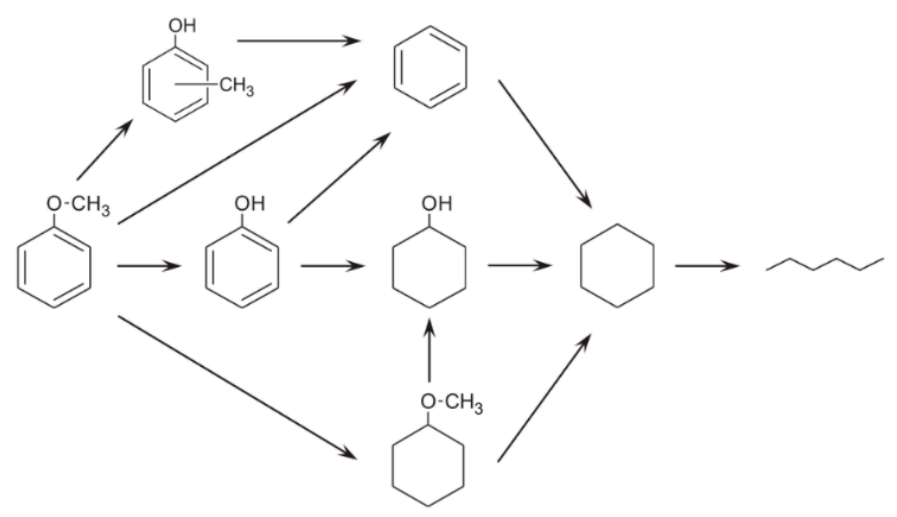

Figure 8. Scheme of the possible routes for anisole HDO from ref [52].

Guaiacol, as another representative lignin depolymerization product, contains abundant phenolic and methoxy groups, which are the basic functional elements of lignin matrix [50]. HDO of guaiacol was widely studied over Ni/CNTs [44,58], Ni/HZSN-5 [46], Raney Ni [59], Ni/Al-MCM-41 [49], Ni/CeO 2 [60], and $\mathrm{Ni} / \mathrm{MgO}$ catalyst [50]. Escalona and co-workers studied the $\mathrm{HDO}$ of guaiacol over $\mathrm{Ni} / \mathrm{CNTs}$ at $300{ }^{\circ} \mathrm{C}$ under $5 \mathrm{MPa}$ and found that the hydrogenation (HYD) of the aromatic ring of guaiacol occurred initially and subsequently demethoxylation (DMO) was observed [44]. It should be pointed out that higher temeprature benefits the HDO of guaiacol due to its high bond energy of C-O bonds. Zhao and Lercher explored the synergistic effects between $\mathrm{Ni}$ metal and acidic sites for hydrogenation and C-O bond cleavage of guaiacol over Ni/HZSM- 5 and achieved $\sim 18 \%$ conversion at $200{ }^{\circ} \mathrm{C}$ and under $3.0 \mathrm{MPa} \mathrm{H}_{2}$ [61]. Three types of $\mathrm{C}-\mathrm{O}$ bonds including $\mathrm{C}_{(\mathrm{sp} 3)}-\mathrm{OAr}$ (bond dissociation energy (BDE): 262 276 kJ/mol), $\mathrm{C}_{(\mathrm{sp} 2)}-\mathrm{OMe}(409 \sim 421 \mathrm{~kJ} / \mathrm{mol})$, and $\mathrm{C}_{(\mathrm{sp} 2)}-\mathrm{OH}(466 \mathrm{~kJ} / \mathrm{mol})$ are present in a guaiacol molecule. As shown in Figure 9, phenol (including its subsequent hydrodeoxygenation products cyclohexanone, cyclohexanol, and cyclohexane) is the only major product (at $t=20 \mathrm{~min}$, selectivity $=78 \%$ ) due to the highest bond energy barrier of $\mathrm{C}_{(\mathrm{sp2})}-\mathrm{OH}$ bond.

Besides empolying lignin monomer compounds in HDO reaction, the HDO of lignin dimer model compounds were also extensively studied. There are mainly three types of aryl-ether linkages in lignin dimers, and the order of the bond dissociation energies follow: $\alpha-\mathrm{O}-4(\sim 215 \mathrm{~kJ} / \mathrm{mol})<\beta-\mathrm{O}-4$ $(\sim 290 \mathrm{~kJ} / \mathrm{mol})<4-\mathrm{O}-5(\sim 330 \mathrm{~kJ} / \mathrm{mol})$ [62]. Liang and co-workers reported the HDO of diphenyl ether, used as a model compound to investigate the C-O bond cleavage of a 4-O-5 aryl ether (the Caryl-O bond with the highest bond dissociation energy) over $\mathrm{Ni} / x \mathrm{Nb} / \mathrm{AC}$ catalysts. The diphenyl ether was almost entirely transformed into cyclohexane with a $67 \%$ selectivity at a W/F (weight of catalyst: feedgas flowrate) of $27.5 \mathrm{~min}$. The aromatic rings were first hydrogenated and then the C-O bond started to break [35]. The main products of the HDO of lignin model compound over Ni-based catalysts supported on neutral or acid support were alkanes such as cyclohexane, toluene, ethylcyclohexane etc., as shown in Table 1. However, cyclohexanol was obtained as a major product in HDO of guaiacol over $\mathrm{Ni} / \mathrm{MgO}$ catalyst, indicating that the base carrier probably supresses the dehydration process [50]. 
(a) Guaiacol HDO

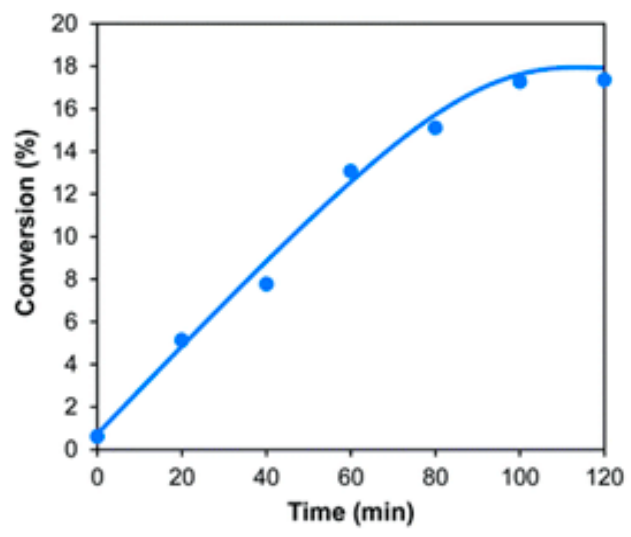

\section{(b) Product distribution}

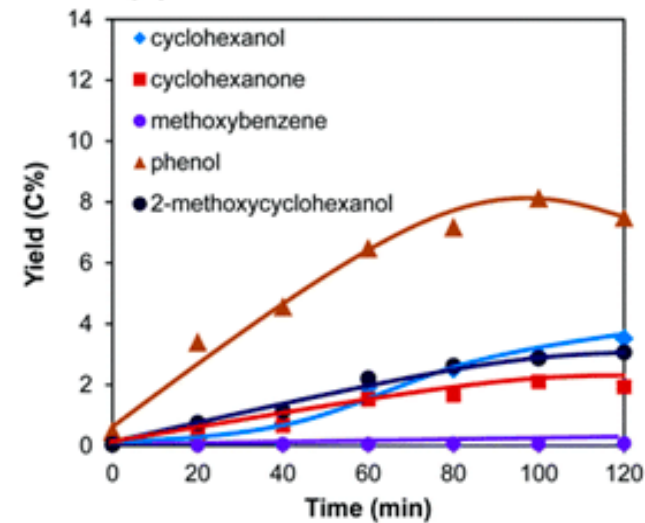

(c) Proposed pathway

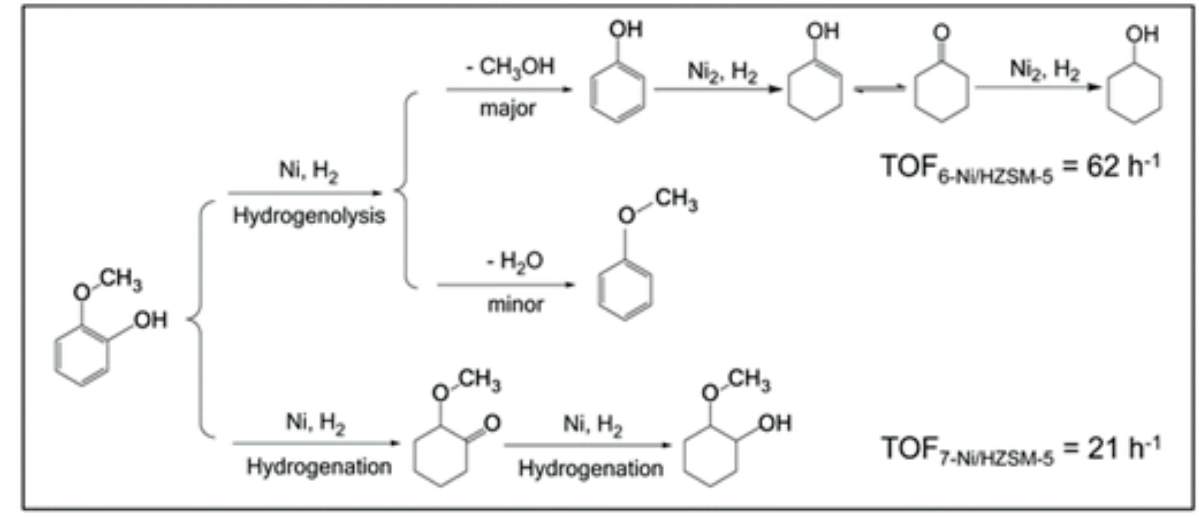

Figure 9. Guaiacol hydrodeoxygenation over Ni/HZSM-5, (a) conversion, (b) product distribution, (c) proposed reaction pathway for ref [44].

$\beta$-O-4 linkage is the most abundant $\mathrm{C}-\mathrm{O}$ bond in lignin, occurring with a frequency of approximately $43 \%$ (softwood) to $65 \%$ (hardwood) [63]. Xu et al. investigated the cleavage of $\beta$-O-4 lignin dimer model compound 2-phenoxy-1-phenylethanone over $\mathrm{Ni} / \mathrm{ZnO}-\mathrm{Al}_{2} \mathrm{O}_{3}$ with varying $\mathrm{Zn} / \mathrm{Al}$ ratios at $250{ }^{\circ} \mathrm{C}$ and under $2 \mathrm{MPa}$ of $\mathrm{H}_{2}$ atmosphere [42]. The high selectivity of ethylcyclohexane was obtained over $\mathrm{Ni} / \mathrm{ZnO}-\mathrm{Al}_{2} \mathrm{O}_{3}-5$ and the conversion reached $100 \%$. Two parallel competitive pathways were elucidated: (a) the reaction mainly proceeds through the hydrogenation of the keto group in $\beta-\mathrm{O}-4$ ketone to produce $\beta-\mathrm{O}-4$ alcohol rather than hydrogenolysis of $\beta-\mathrm{O}-4$ ether bond at low temperature; (b) the substrate first was cleaved into acetophenone and phenol via the hydrogenolysis step at a relatively high temperature. The possible pathway was displayed in Figure 10. Recently, Zhao and Lercher investigated the HDO of a series of phenolic momers with a selectivity to cyclohexanes in the range of $73-92 \%$ and good stability was observed over Ni/HZSM-5 at $250{ }^{\circ} \mathrm{C}$ and $5.0 \mathrm{MPa}$ $\mathrm{H}_{2}$ [47]. Meanwhile, this catalyst was used in converting phenol dimers and the selectivity of $\mathrm{C}_{6}-\mathrm{C}_{8}$ hydrocarbons exceeds $60 \%$.

Transition metal phosphide such as $\mathrm{Ni}_{2} \mathrm{P}$ had also been applied in the HDO of lignin-derived feedstock recently [54-57]. The superiority of these transition metal Ni phosphide catalysts were high activity and low cost compared to noble metal catalysts. Richard and co-workers studied the HDO of cresol isomers (i.e., m-cresol, p-cresol, o-cresol) over $\mathrm{Ni}_{2} \mathrm{P} / \mathrm{SiO}_{2}$ and found that the reactivity of cresols followed the order: $\mathrm{m}$-cresol $>\mathrm{p}$-cresol $>\mathrm{o}$-cresol. This could be explained by the fact that the HDO route was more influenced by the position of the methyl group than HYD route [56]. Besides, the author proposed that Brønsted acidic sites (probably PO-H groups) as well as Lewis acidic sites $\left(\mathrm{Ni}^{\delta+}\right.$ species) were involved in dehydration and isomerization reactions, respectively [56]. 


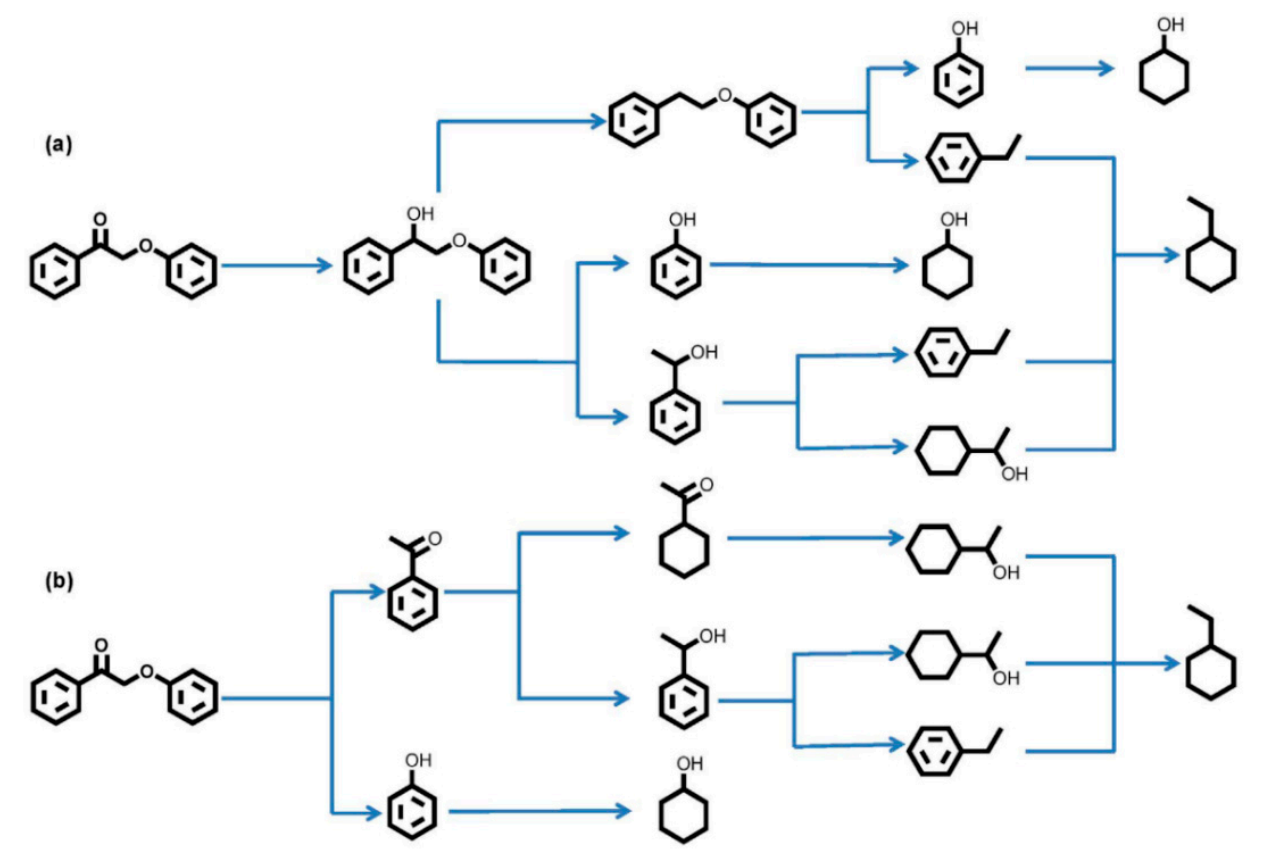

Figure 10. Proposed reaction pathways of 2-phenoxy-1-phenylethanone conversion on Ni/ $\mathrm{ZnO}^{-} \mathrm{Al}_{2} \mathrm{O}_{3}-5$ form ref [42].

The search for a catalyst for efficient HDO of lignin macromolecules, which are rich in aromatic rings and of high energy density, into chemicals and value-added fuels has been the question that intrigued the researchers. The complexity of three-dimensional cross-linking polymeric structure of lignin leads to its low solubility in conventional organic solvents [64]. However, it should be pointed out that the catalysts used in HDO of lignin model compounds may not be appropriate for real lignin macromolecular depolymerization. As a result, only a few literature reports were found for Ni-based catalysts, such as Ni on amorphous silica-alumina (ASA), in the HDO of lignin into phenolics or alkanes liquid fuels $[33,64,65]$. Zhao and Lercher screened a series of nickel-based catalyst including $\mathrm{Ni} / \mathrm{ZrO} \mathrm{O}_{2}$, $\mathrm{Ni} / \mathrm{ZnO}, \mathrm{Ni} / \mathrm{TiO}_{2}, \mathrm{Ni} / \mathrm{MgO}, \mathrm{Ni} / \mathrm{SiO}_{2}, \mathrm{Ni} / \mathrm{Al}_{2} \mathrm{O}_{3}, \mathrm{Ni} / \mathrm{ASA}$ in hydroconversion of cellulolytic enzyme lignin (CEL) into naphthenes and paraffins [64]. The highest liquid yield (46.2 wt \%) was achieved over $\mathrm{Ni} / \mathrm{ASA}$ catalyst at $300{ }^{\circ} \mathrm{C}$ under pressure of $6 \mathrm{MPa} \mathrm{H}_{2}$. The products included a selectivity of $80.8 \%$ $\mathrm{C}_{3}-\mathrm{C}_{9}, 6.5 \%$ of $\mathrm{C}_{10}-\mathrm{C}_{14}$, and $12.7 \%$ of $\mathrm{C}_{14}-\mathrm{C}_{17}$, as shown in Figure 11 . The author also indicated that the crucial fragments from lignin depolymerization were substituted phenols and alcohols through hydrogenolysis of C-O bonds, and then rapidly were converted into cyclohexanes and alkanes via HDO. In addition, Wang et al. investigated the HDO of organsolv lignin over Ni/Al-SBA-15 catalyst with selectivity to cyclic alkanes higher than 99\%, which was highly promising for the production of drop-in transportation fuel. GC-MS image displaying the product distribution was shown in Figure 12 [33].

\subsection{Ni-Based Bimetallic Catalysts for HDO of Lignin}

Compared with monometallic catalyst, HDO of lignin over bimetallic catalysts became a promising strategy due to the flexibility to modify the catalyst property and tune the selectivity of the target products. Bimetallic catalysts $\mathrm{ReNi} / \mathrm{ZrO}_{2}$ [66], $\mathrm{PtNi} / \mathrm{Al}_{2} \mathrm{O}_{3}$ [67], $\mathrm{RuNi} / \mathrm{HZSM}-5$ [78], $\mathrm{NiCu} / \mathrm{Al}_{2} \mathrm{O}_{3}$ [68], $\mathrm{ReNi} / \mathrm{SiO}_{2}$ [70], $\mathrm{RuNi} / \mathrm{HY}$ [74], $\mathrm{NiMo} / \mathrm{Al}_{2} \mathrm{O}_{3}$ [72], $\mathrm{NiAu}$ [71], etc. were extensively studied for the HDO of lignin model compounds, as shown in Table 4. These bimetallic catalysts aim at balancing the activity and selectivity of deoxygenation and hydrogenation steps [70]. In comparison with the monometallic catalysts, bimetallic catalysts exhibit a distinct improvement in HDO selectivity due to various "synergistic effects". 
(a)

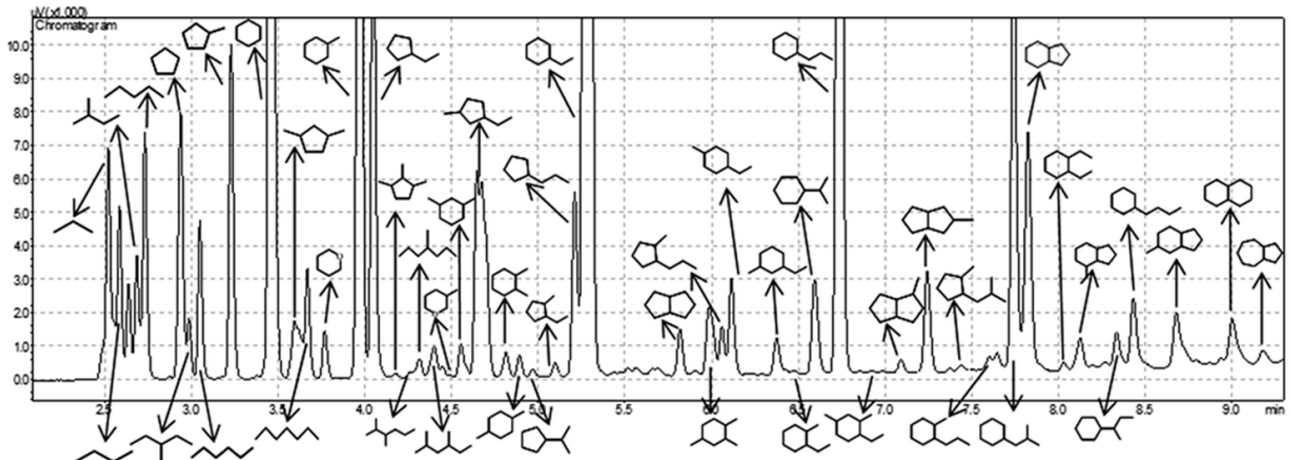

(b)

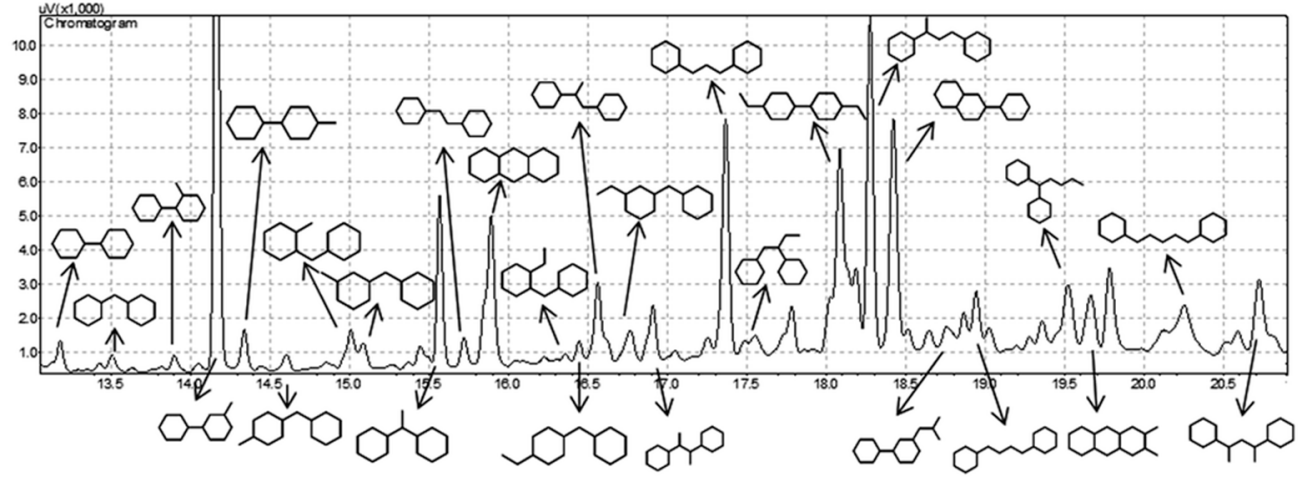

Figure 11. Liquid products of (a) $\mathrm{C}_{3}-\mathrm{C}_{10}$ and (b) $\mathrm{C}_{12}-\mathrm{C}_{17}$ hydrocarbons from one-pot lignin conversion over Ni/ASA for ref [64].

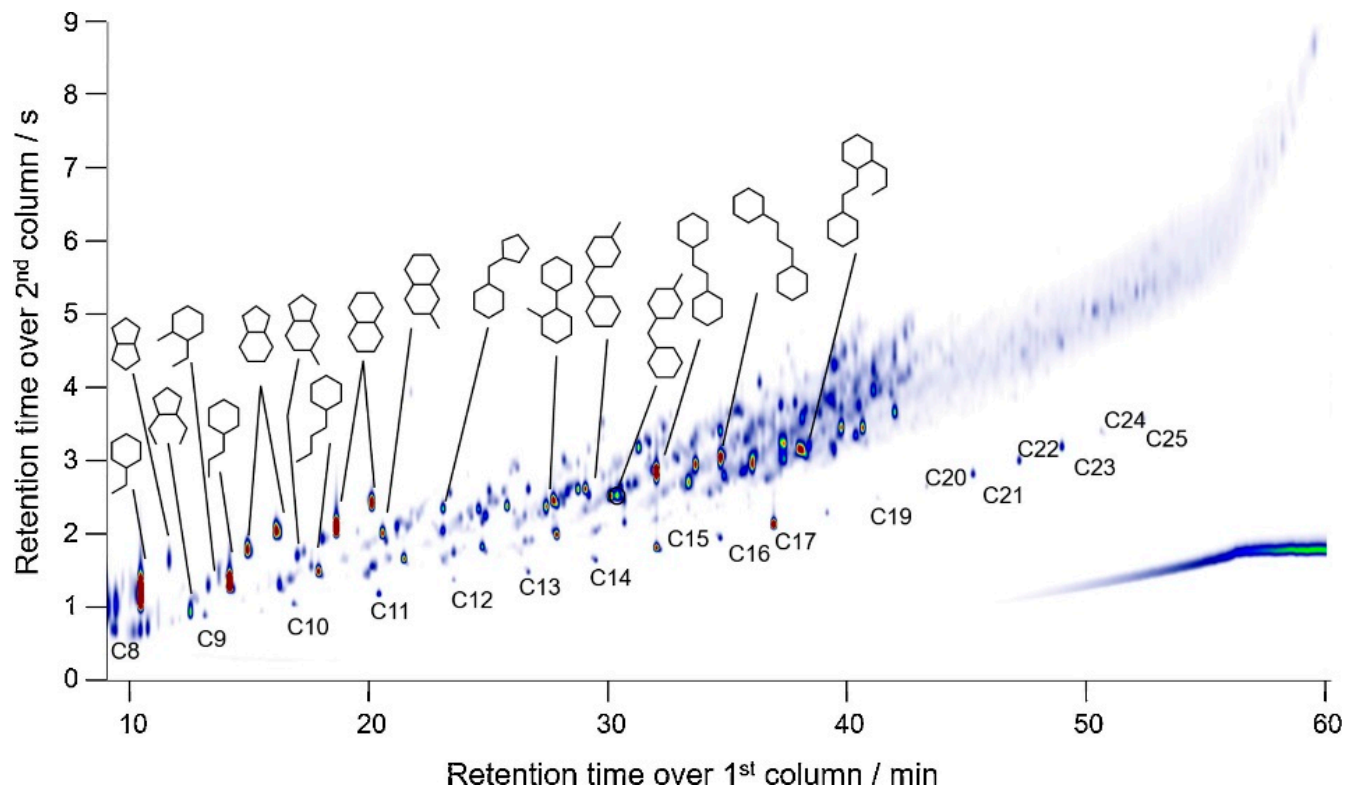

Figure 12. GC-MS image of the products obtained from the HDO of organsolv lignin for ref [33]. 
Table 4. HDO of lignin model compounds and lignin over Ni-based bimetallic catalysts.

\begin{tabular}{|c|c|c|c|c|c|c|c|c|c|c|}
\hline \multirow[b]{2}{*}{ Cat. } & \multicolumn{5}{|c|}{ Reaction Conditions } & \multirow[b]{2}{*}{ Substrate } & \multirow[b]{2}{*}{ Major Products } & \multirow[b]{2}{*}{ Conv.(\%) } & \multirow[b]{2}{*}{ Reactor } & \multirow[b]{2}{*}{ Ref } \\
\hline & $\begin{array}{l}\text { Ni Loading } \\
\text { (wt \%) }\end{array}$ & Support & $\mathrm{T}\left({ }^{\circ} \mathrm{C}\right)$ & P (MPa) & Solvent & & & & & \\
\hline $\mathrm{Re}-\mathrm{Ni}$ & 10 & $\mathrm{ZrO}_{2}$ & 300 & 4.0 & $\mathrm{H}_{2} \mathrm{O}$ & 4-propylphenol & n-propylbenzene & 91.0 & Batch & {$[66]$} \\
\hline $\mathrm{Pt}-\mathrm{Ni}$ & 5 & $\mathrm{Al}_{2} \mathrm{O}_{3}$ & 260 & 0.1 & - & $\mathrm{m}$-Cresol & toluene & 62.7 & Fixed-bed & [67] \\
\hline $\mathrm{Ni}-\mathrm{Cu}$ & 10 & $\mathrm{Al}_{2} \mathrm{O}_{3}$ & 300 & $4.5 \mathrm{~N}_{2}$ & isopropanol & p-cresol & 4-methyl-cyclohexanol & 100.0 & Batch & [68] \\
\hline $\mathrm{Pd} / \mathrm{Ni}$ & - & - & 240 & $1.0 \mathrm{~N}_{2}$ & 2-propanol & diphenyl ether & benzene & 96.0 & Batch & [69] \\
\hline $\mathrm{Ni}-\mathrm{Re}$ & 5 & $\mathrm{SiO}_{2}$ & 300 & 0.1 & - & m-Cresol & toluene & 47.6 & Fixed-bed & [70] \\
\hline $\mathrm{Ni}-\mathrm{Au}$ & - & - & 130 & 1.0 & $\mathrm{H}_{2} \mathrm{O}$ & 2-Phenoxy-1-phenylethanol & monomers & $\sim 60.0$ & Batch & [71] \\
\hline $\mathrm{Ni}-\mathrm{Mo}$ & $1-5$ & $\mathrm{Al}_{2} \mathrm{O}_{3}$ & 450 & 2.07 & - & 4-Propylguaiacol & 4-propylphenol & $>90.0$ & Fixed-bed & [72] \\
\hline Ni-Mo-4Ce & 6.2 & - & 300 & 1.0 & - & guaiacol & $\begin{array}{c}\text { phenol, } \\
\text { 1,2-benzenediol }\end{array}$ & 56.7 & Fixed-bed & [73] \\
\hline $\mathrm{Ru}-\mathrm{Ni}$ & 2.5 & $\mathrm{HY}$ & 250 & 4.0 & $\mathrm{H}_{2} \mathrm{O}$ & guaiacol & cyclohexane & 95.0 & Batch & [74] \\
\hline $\mathrm{Ni}-\mathrm{W}$ & 2.3 & $\mathrm{AC}$ & 150 & 1.5 & n-octane & phenol & cyclohexane & 56.2 & Fixed-bed & [75] \\
\hline $\mathrm{Ru}-\mathrm{Ni}$ & 2.5 & HY & 250 & 4.0 & $\mathrm{H}_{2} \mathrm{O}$ & soft wood lignin & hydrocarbons & $>80.0$ & Batch & [74] \\
\hline $\mathrm{Ni}-\mathrm{Nb}$ & - & bulk & 160 & 3 & n-dodecane & anisole & $\begin{array}{l}\text { cyclohexane, } \\
\text { cyclohexanol }\end{array}$ & 95.3 & Batch & {$[76,77]$} \\
\hline
\end{tabular}


Zhu and co-workers investigated the selective deoxygenation of m-cresol over $\mathrm{Ni}-\mathrm{Re} / \mathrm{SiO}_{2}$ catalyst at $300{ }^{\circ} \mathrm{C}$ and under $0.1 \mathrm{MPa} \mathrm{H}_{2}$ in a fixed-bed reactor [70]. Obviously, the HDO conversion over $5 \mathrm{Ni} 2.5 \mathrm{Re} / \mathrm{SiO}_{2}$ catalyst was much higher than monometallic catalysts $\mathrm{Ni} / \mathrm{SiO}_{2}, 2.5 \mathrm{Re} / \mathrm{SiO}_{2}$, and $2.5 \mathrm{ReO}_{x} / \mathrm{SiO}_{2}$. Interestingly, the selectivity to toluene over bimetallic catalyst $5 \mathrm{Ni} 2.5 \mathrm{Re}$ was significantly higher than that over monometallic catalysts. The proposed mechanism for selective deoxygenation of m-cresol over bimetallic Ni-Re catalysts was shown in Figure 13. These results demonstrated that the incorporation of a second metal could adjust the activity and tailor the desired product selectivity. After taking the $\mathrm{NH}_{3}$-TPD results into account, it was revealed that the number of acidic sites increases with increasing Re loading, and new acidic sites are formed in the presence of Re upon reduction. Fukuok et al. also proposed a $\mathrm{ReNi} / \mathrm{ZrO}_{2}$ catalyst for the $\mathrm{HDO}$ of 4-propylphenol to n-propylbenzene in aqueous-phase and concluded that addition of Re decreases the Ni particle size and significantly improved the catalytic activity and enhanced the selectivity to n-pylbenzene [66].

Apart from using water as solvent for the HDO of lignin model compounds, $\mathrm{H}$-donor solvents such as alcohols were also investigated in this system over bimetallic Ni-based catalysts. This kind of hydrogenation strategy was known as the catalytic transfer hydrogenation (CTH), in which the solvent is the source of hydrogen, rather than molecular hydrogen (often derived from fossil fuels) [68]. Boateng and co-wokers reported a bimetallic $\mathrm{NiCu} / \mathrm{Al}_{2} \mathrm{O}_{3}$ catalyst in $\mathrm{CTH}$ of $p$-cresol using isopropanol as solvent [68]. The influence of using isopropanol as co-solvent was discussed and it was found that as the concentration of water increased, the activity decreased as well as the yield of 4-methylcyclohexanol, while the yield of 4-methylcyclohexanone increased. Figure 14 showed the reaction pathway of the $\mathrm{CTH}$ of p-cresol using isopropanol over $\mathrm{Al}_{2} \mathrm{O}_{3}, \mathrm{Ni}, \mathrm{Cu}$, and $\mathrm{NiCu} / \mathrm{Al}_{2} \mathrm{O}_{3}$ catalysts. Additionally, bimetallic $\mathrm{Pd} / \mathrm{Ni}$ catalysts were prepared and used in $\mathrm{CTH}$ of lignin-derived aromatic ethers including diphenyl ether, 2-phenethyl phenyl ether, and benzyl phenyl ether as 4-O-5, $\beta-\mathrm{O}-4$, and $\alpha-\mathrm{O}-4$ model compounds using 2-propanol as solvent [69]. The CTH of diphenyl ether was investigated in details, the diphenyl ether was at first converted into benzene and phenol via transfer hydrogenolysis, and then benzene and phenol were completely hydrogenated via transfer hydrogenation into cyclohexane and cyclohexanol. The reaction pathway was listed in Figure 15. Moreover, bimetallic Pd/Ni catalysts exhibited good stability in eight consecutive recycling tests.

The advantages of adding another metal may result from four different effects which can be summarized as geometric effects [70], electronic effects [70,78], synergistic effects [66], and bifunctional effects [63,70]. Addition of Re to Ni catalyst could increase the Ni particles dispersion, breaking the continuous Ni surface into smaller ensembles, which leads to Ni-Re surface alloy formation. The Re in such a bifunctional complex thus acted as the active sites for $\mathrm{O}$ atom adsorption. Such an effect is an example of a geometric effect and could inhibit C-C bond hydrogenolysis [70]. The presence of Re could also reduce the d-band electron density of $\mathrm{Ni}$, which is an example of electronic effect. Such an effect could weaken the adsorption of the aromatic ring. Thus, addition of Re to the Ni metal catalyst leads to reduced methane production, increased activity of deoxygenation, and better aromatic ring preservation.

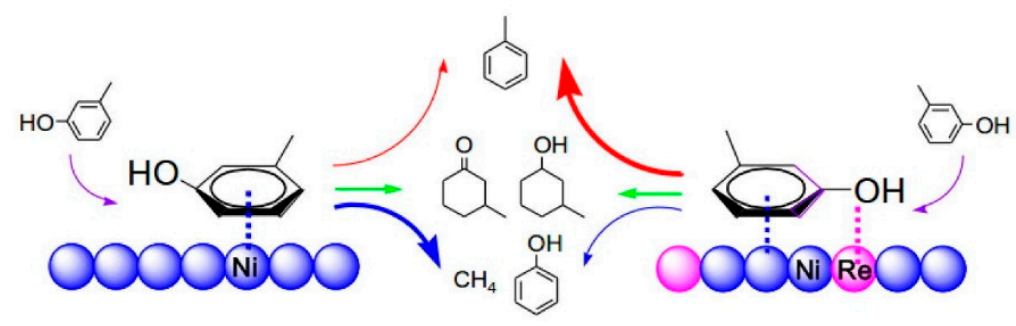

Figure 13. Proposed mechanism for selective deoxygenation of m-cresol over bimetallic Ni-Re catalysts for ref [70]. 


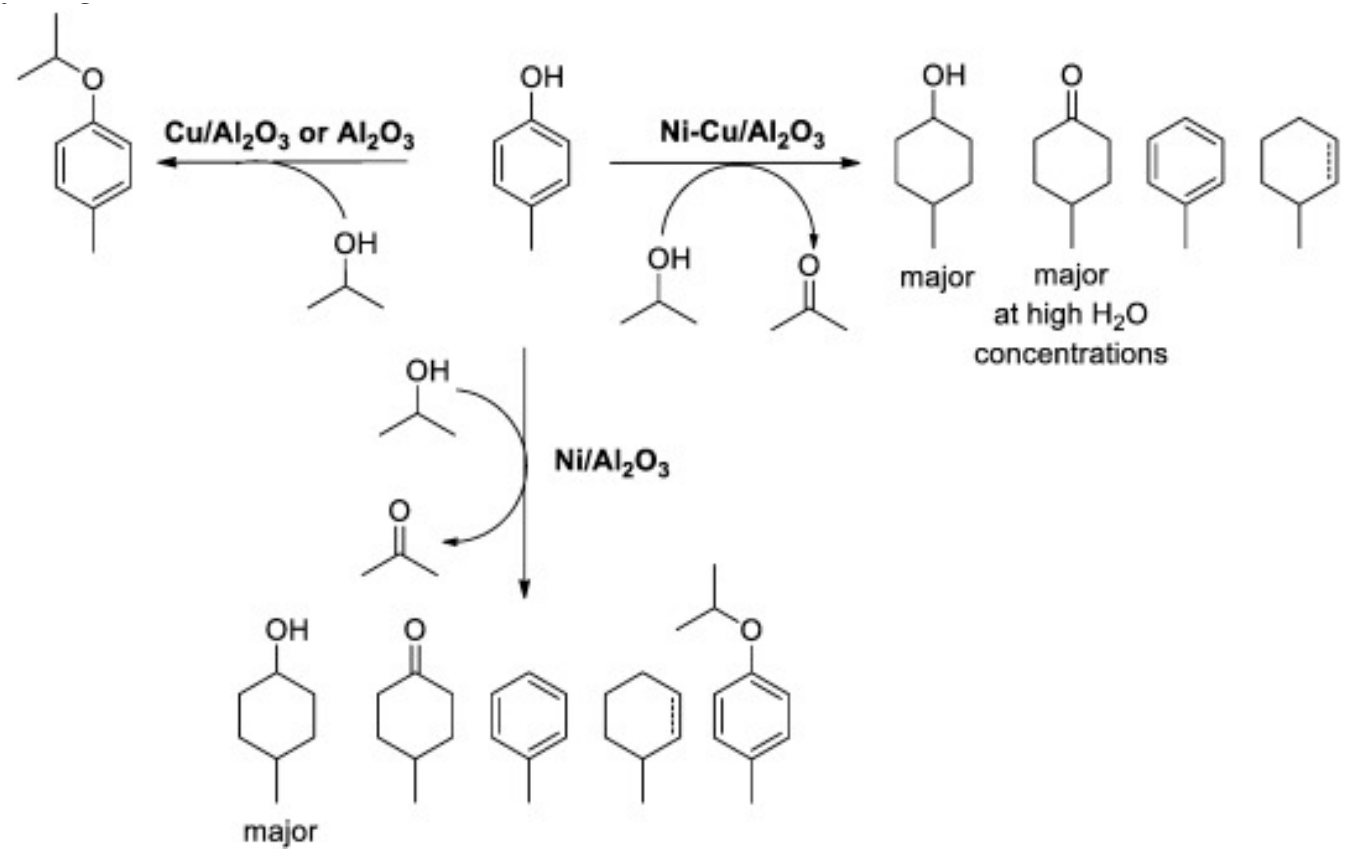

Figure 14. Transfer hydrogenation of p-cresol using isopropanol over $\mathrm{Al}_{2} \mathrm{O}_{3}, \mathrm{Ni}, \mathrm{Cu}$, and $\mathrm{NiCu} / \mathrm{Al}_{2} \mathrm{O}_{3}[68]$.

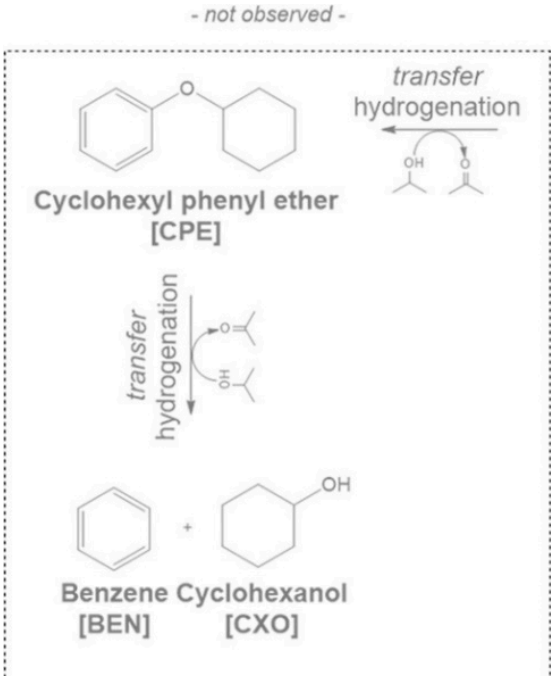

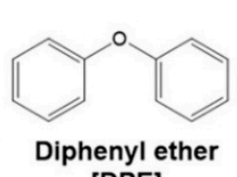

[DPE]

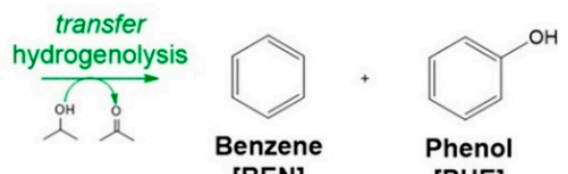

[BEN] [PHE]
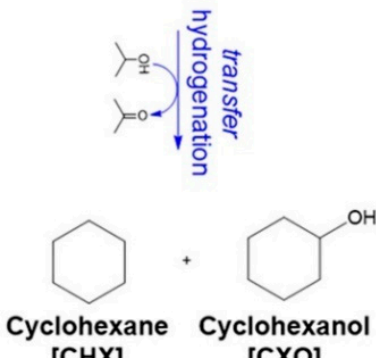

$[\mathrm{CHX}] \quad[\mathrm{CXO}]$

Figure 15. Possible catalytic pathways in the catalytic transfer hydrogenolysis of diphenyl ether for ref [69].

\subsection{Ni-Based Catalysts for HDO of Real Lignin Feedstock}

Apart from Ni-based catalysts addressed in HDO of lignin model compounds, upgrading of real lignin feedstock through HDO over Ni-based catalysts have also aroused wide public concern. Yang and co-workers compared the $\mathrm{HDO}$ of soft wood lignin over various catalyst in $\mathrm{H}_{2} \mathrm{O}$ at $250{ }^{\circ} \mathrm{C}$ under pressure of $4.0 \mathrm{MPa} \mathrm{H}_{2}$ [74]. RuNi/HY catalyst exhibited high conversion $(>80 \%)$ and the highest yield of hydrocarbon among various bimetallic $\mathrm{Ru} / \mathrm{HY}$ catalysts. However, owing to the relatively higher hydrocarbon selectivities over $\mathrm{RuCu} / \mathrm{HY}$ catalyst than other catalysts, $\mathrm{RuCu} / \mathrm{HY}$ catalyst was then selected in subsequent investigations. Meier et al. systematically researched the catalytic hydropyrolysis of Kraft lignins over sulfided NiMo on aluminosilica catalysts and achieved $65 \mathrm{wt} \%$ yield to oil, which contained larger amounts of monomeric phenols. [80-82] Narani et al. prepared a variety of sulfided $\mathrm{NiW}$ catalysts on acidic, neutral, and basic supports for transformation 
of kraft lignin to aromatic monomers in supercritical methanol. These results revealed the sulfided $\mathrm{NiW} / \mathrm{AC}$ (activated carbon) catalyst showed the best results with a total $28 \mathrm{wt} \%$ monomer yield and $76 \%$ selectivity to alkylphenolics and guaiacolics, as shown in Figure 16. [79] After comparing these catalysts, the authors found that the support played an important role in the catalytic conversion of Kraft lignin. AC or $\mathrm{MgO}-\mathrm{La}_{2} \mathrm{O}_{3}$ presented the highest monomer yields, which were better than those over acidic supports (with high yield to char). Kumar et al. investigated solvent free depolymerization of kraft lignin to alkyl-phenolics over supported sulfided NiMo catalysts at $350{ }^{\circ} \mathrm{C}, 10 \mathrm{MPa}_{2}$. [83] They also found that the support had greatly influenced the depolymerization and the yield of monomer. The catalyst activity increased as follows: $\mathrm{Al}_{2} \mathrm{O}_{3}<\mathrm{ZSM}-5<\mathrm{AC}=\mathrm{MgO}-\mathrm{La}_{2} \mathrm{O}_{3}$. The highest total yield of monomers were achieved over sulfided $\mathrm{NiMo} / \mathrm{MgO}-\mathrm{La}_{2} \mathrm{O}_{3}$ with $26.4 \mathrm{wt} \%$, which included $15.7 \mathrm{wt} \%$ alkyl-phenolics. Despite good results having been achieved, the development of Ni-based catalysts and optimization of chemical processes with high selectivity to monomers is still a challenge for the HDO of real lignin feedstock.

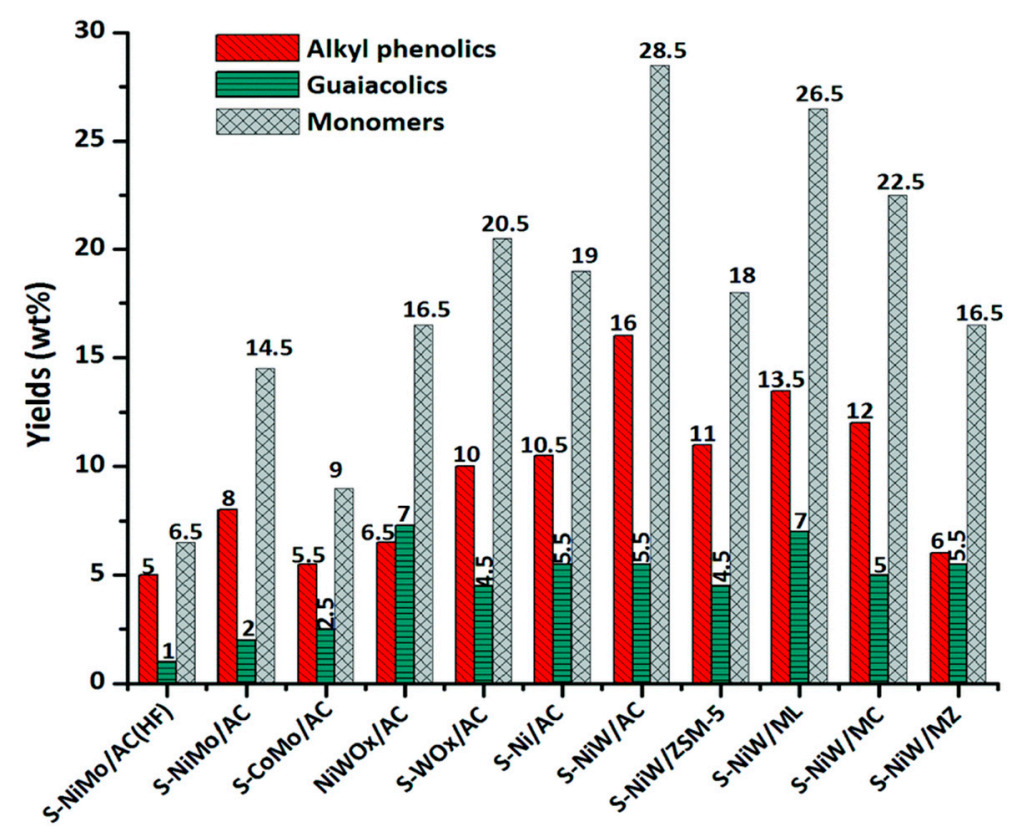

Figure 16. Effect of catalysts on alkylphenolics, guaiacolics, and monomer yields [79].

\section{Hydrogenolysis}

While HDO of lignins and lignin-derived model compounds and lignin is suitable for production of fuel components, hydrogenolysis or hydrolysis of lignin can be applied to produce a wide variety of oxygenated chemicals, since the oxygen atoms and aromaticity can be retained by catalyst properties tuning. Compared with HDO, hydrogenolysis of lignin and lignin-derived compounds generally involves the cleavage of the various $\mathrm{C}-\mathrm{O}$ bonds by $\mathrm{H}_{2}$, with or without the retention of the oxygen atoms. Therefore, they are suitable to depolymerize lignin into value-added chemicals such as BTX (benzene, toluene, and xylene), liquid alkane via HDO. The first reaction between hydrogen gas and lignin was dated back as early as 1938, where lignin was found to be depolymerized by Cu-Cr catalyst

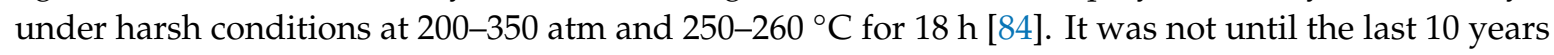
that this field of research revived again due to the potentials of using lignocellulosic biomass for sustainable fuels and chemicals productions. In this regard, both monometallic and multi-metallic $\mathrm{Ni}$ catalysts with and without supports have played important roles in the development of this field. Compared with HDO, there are many more examples of hydrogenolytic depolymerization of lignin macromolecules. As shown in Table 5, of the 44 literature reports found, 28 of them mentioned the direct hydrogenolysis of lignin or wood to aromatics, phenolic, and naphthenes monomers and some of them were performed in continuous flow manners. 


\subsection{Monometallic Ni-Based Catalysts for Hydrogenolysis of Lignin}

Since the discovery of Raney nickel in 1926, it has been used in numerous industrial processes, especially in the hydrogenation reactions. Although the hydrogenolysis and hydrogenation of ethers by Raney Nickel have been known for a long time $[85,86]$, it was not until only recently that it was thoroughly investigated in the application of hydrogenolysis of lignin model compounds and lignin. Rinaldi et al has investigated the solvent effects on the hydrolysis of diphenyl ether with Raney nickel [62]. It was shown that the solvent effect has played an important role on the catalytic activity and the control of selectivity. Basic solvents such as 1,4-dioxane and methanol can suppress the hydrogenation of aromatic rings but have little effect on hydrogenolysis activity. In other words, if alkanes and cyclohexanes are the desired products, solvents with no Lewis basicity should be used. As a results, Klason lignin has been successfully depolymerized using methanol as solvent to produce bio-oil containing aromatic monomers, such as phenol, corylon, guaiacol, syringol, vanillin, etc. in high yield [87]. Hydrogenolysis of lignin had also been performed under subcritical water conditions to produce bio-oil and the product distributions had been investigated. With the use of Raney nickel, catechols can further be deoxygenated to phenols [88]. Thus, it is a good way to produce highly reactive phenol and its para- and ortho-alkylated derivatives in high yield and good selectivity. Apart from thermochemical method, lignin can also be valorized by the electrochemical method. Using Raney nickel as the cathode and cobalt-phosphate as the anode materials, the aryl-ether bond of guaiacol was first cleaved to form phenol, followed by hydrogenation of phenol to cyclohexanol in high selectivity (91\%) [89].

Compared with noble metal catalysts such as $\mathrm{Ru}$ and $\mathrm{Pd}$, Ni-based catalysts generally demonstrated lesser reactivity but higher selectivity, especially to aromatic monomers [90]. Since the discovery of homogeneous catalytic hydrogenolysis of lignin model compounds bearing $\alpha-\mathrm{O}-4, \beta-\mathrm{O}-4$ and $4-\mathrm{O}-5$ linkage by a Ni carbene complex in 2011 [130], numerous conversion studies have been performed using heterogeneous Ni catalysts. For the heterogeneous hydrogenolysis of phenethyl phenyl ether, $\mathrm{Ni} / \mathrm{AC}$ demonstrated a lower conversion $(18 \%)$ but with highest selectivity $(75 \%)$ towards benzene and phenethyl alcohol. The conversion yields are even lower if MWCNTs and $\mathrm{Al}_{2} \mathrm{O}_{3}$ were used as the support. Active carbon (AC) support was capable of facilitating the reducibility of $\mathrm{NiO}$ to metallic Ni at a lower temperature $\left(400^{\circ} \mathrm{C}\right)$ than with MWCNTs $\left(550{ }^{\circ} \mathrm{C}\right)$. The presence of nickel aluminate and $\mathrm{NiAl}_{2} \mathrm{O}_{4}$ spinel was also the reason for the difficult reduction for $\mathrm{Ni} / \mathrm{Al}_{2} \mathrm{O}_{3}$ catalysts. Finally, the larger particle size of $\mathrm{Ni}$ in $\mathrm{Ni} / \mathrm{Al}_{2} \mathrm{O}_{3}$ catalyst also contribute to its lower catalytic activity towards hydrogenolysis of dimer model compounds [90]. Ni/C has been shown to depolymerize birch wood lignin effectively with $50 \%$ conversion and $97 \%$ selectivity towards monomeric phenols. It was postulated that with hydrogen donor solvents such as methanol, lignin was first fragmented into lignin with smaller molecular weight $(1100-1600 \mathrm{~m} / \mathrm{z})$ via methanolysis, followed by the further degradation into phenols over $\mathrm{Ni} / \mathrm{C}$ catalysts [91]. 
Table 5. Hydrogenolysis of lignin model compounds and lignin over monometallic and bimetallic Ni catalysts.

\begin{tabular}{|c|c|c|c|c|c|c|c|c|c|c|}
\hline \multirow[b]{2}{*}{ Cat. } & \multicolumn{5}{|c|}{ Reaction Conditions } & \multirow[b]{2}{*}{ Substrate } & \multirow{2}{*}{ Major Products } & \multirow{2}{*}{$\begin{array}{c}\text { Max. } \\
\text { Performance } \\
\text { Obtained (\%) }\end{array}$} & \multirow{2}{*}{$\begin{array}{c}\text { Reactor } \\
\text { Type }\end{array}$} & \multirow[b]{2}{*}{ Ref } \\
\hline & $\begin{array}{l}\text { Ni Loading } \\
\text { (wt \%) }\end{array}$ & Support & $\begin{array}{l}\text { T }\left({ }^{\circ} \mathrm{C}\right) \& \\
\text { Time (h) }\end{array}$ & $\begin{array}{l}\text { Pressure } \\
\text { (MPa) }\end{array}$ & Solvent & & & & & \\
\hline $\mathrm{Ni}$ & 5 & $\mathrm{AC}$ & 150 & $0.7-0.8$ & $\mathrm{CH}_{3} \mathrm{OH}$ & phenyl ether & $\begin{array}{l}\text { aromatic alcohol, } \\
\text { benzene }\end{array}$ & $\begin{array}{c}\text { conv. }(18 \%) \\
\text { select. }(75 \%)\end{array}$ & Batch & [90] \\
\hline $\mathrm{Ni}$ & 10 & $\mathrm{AC}$ & $\begin{array}{c}200 \\
6\end{array}$ & 0.1 & $\begin{array}{c}\text { hydrogen } \\
\text { donor solvents }\end{array}$ & birch sawdust & aromatic products & $\begin{array}{l}\text { phenol selectivity } \\
(97 \%) \text {, conv. }(50 \%)\end{array}$ & Batch & [91] \\
\hline $\mathrm{Ni}$ & 10 & $\mathrm{AC}$ & 200 & 5 & $\begin{array}{l}\text { ethylene } \\
\text { glycol }\end{array}$ & lignosulfonate & $\begin{array}{c}\text { 4-ethyl-guaiacol, } \\
\text { 4-propyl-guaiacol } \\
\text { and dimers }\end{array}$ & conv. $(91 \%)$ & Batch & [92] \\
\hline $\mathrm{Ni}$ & 5 & $\mathrm{CB}$ & 80 & 0.2 & $\begin{array}{c}\mathrm{NaBH}_{4}, \\
\text { EtOH/H}{ }_{2} \mathrm{O}, \\
\text { liquid phase }\end{array}$ & $\begin{array}{l}\text { benzyl phenyl } \\
\text { ether }\end{array}$ & phenol, toluene & $\begin{array}{l}\text { conv. }(99 \%) \\
\text { select. to toluene } \\
(46 \%) \\
\text { select. to phenol } \\
(45 \%)\end{array}$ & Batch & [93] \\
\hline $\mathrm{Ni}$ & 5 & $\mathrm{AC}$ & $\begin{array}{c}240 \\
4\end{array}$ & 3 & alcohol & corncob lignin & aromatic phenols & $\begin{array}{l}\text { monomer yield: } \\
12 \% \text { (MeOH as } \\
\text { solvent) }\end{array}$ & Batch & [94] \\
\hline $\mathrm{Ni}$ & 10 & $\mathrm{AC}$ & $\begin{array}{l}200 \\
5\end{array}$ & 2 & $\begin{array}{c}\text { methanol- } \mathrm{H}_{2} \mathrm{O} \\
\text { co-solvent }\end{array}$ & $\begin{array}{l}\text { raw beech } \\
\text { sawdust }\end{array}$ & phenolic alcohols & conv. (51.4 wt \%) & Batch & [95] \\
\hline $\mathrm{Ni}$ & 5 & C & $\begin{array}{c}200-250 \\
1-6\end{array}$ & 3 & $\begin{array}{c}\text { acid } \\
\text { co-catalysts }\end{array}$ & corn stover lignin & $\begin{array}{l}\text { phenolic } \\
\text { monomers }\end{array}$ & $\begin{array}{l}\text { lignin bio-oil } \\
\text { yield: } 55 \%\end{array}$ & Batch & [96] \\
\hline $\mathrm{Ni}$ & 5 & NDC & $\begin{array}{c}240 \\
12\end{array}$ & 2 & $\mathrm{H}_{2} \mathrm{O} / \mathrm{THF}$ & $\begin{array}{c}\beta-\mathrm{O}-4 \text { lignin } \\
\text { model compound }\end{array}$ & $\begin{array}{l}\text { aromatic } \\
\text { monomers }\end{array}$ & conv. $(86 \%)$ & Batch & [97] \\
\hline $\mathrm{Ni}$ & 32 & NDC & $\begin{array}{l}150 \\
24\end{array}$ & 0.8 & ethanol & Kraft lignin & $\begin{array}{l}\text { aromatic } \\
\text { monomers }\end{array}$ & $\begin{array}{c}\text { most ether linkage } \\
\text { cleaved }\end{array}$ & $\begin{array}{l}\text { Batch and } \\
\text { flow }\end{array}$ & [98] \\
\hline $\mathrm{Ni}$ & 10 & MgAlO-C & $\begin{array}{c}200 \\
6\end{array}$ & 1 & methanol & $\begin{array}{c}\beta-\mathrm{O}-4 \text { ketones } \\
\text { oxidized birch } \\
\text { lignin }\end{array}$ & $\begin{array}{l}\text { aromatic } \\
\text { monomers }\end{array}$ & $\begin{array}{c}\beta \text {-O-4 ketones: } \\
\text { conv. (>99\%) } \\
\text { monomer from } \\
\text { birch lignin: } \\
22 \mathrm{wt} \% \text { yield }\end{array}$ & Batch & [99] \\
\hline $\mathrm{Ni}$ & 20 & Al-SBA-15 & $\begin{array}{c}300 \\
4\end{array}$ & 1 & ethanol & $\begin{array}{c}\text { organosolv } \\
\text { hydrolyzed lignin }\end{array}$ & $\begin{array}{l}\text { aromatic } \\
\text { monomers }\end{array}$ & $\begin{array}{c}\text { conv. }(\sim 90 \%) \\
\text { monomer yield: } \\
21.9 \text { wt } \%\end{array}$ & Batch & [100] \\
\hline $\mathrm{Ni}$ & 10 & Al-SBA-15 & $\begin{array}{l}140, \\
0.5\end{array}$ & $\begin{array}{c}400 \mathrm{~W} \\
\text { (Microwave) }\end{array}$ & tetralin & $\begin{array}{l}\text { organosolv olive } \\
\text { tree pruning } \\
\text { lignin }\end{array}$ & bio-oil & $\begin{array}{l}\text { bio-oil yield: } \\
16.94 \%\end{array}$ & $\begin{array}{c}\text { Micro-wave } \\
\text { vessel }\end{array}$ & [101-103 \\
\hline
\end{tabular}


Table 5. Cont.

\begin{tabular}{|c|c|c|c|c|c|c|c|c|c|c|}
\hline \multirow[b]{2}{*}{ Cat. } & \multirow[b]{2}{*}{$\begin{array}{l}\text { Ni Loading } \\
\text { (wt \%) }\end{array}$} & \multicolumn{4}{|c|}{ Reaction Conditions } & \multirow[b]{2}{*}{ Substrate } & \multirow{2}{*}{ Major Products } & \multirow{2}{*}{$\begin{array}{c}\text { Max. } \\
\text { Performance } \\
\text { Obtained (\%) }\end{array}$} & \multirow{2}{*}{$\begin{array}{c}\text { Reactor } \\
\text { Type }\end{array}$} & \multirow[b]{2}{*}{ Ref } \\
\hline & & Support & $\begin{array}{l}\text { T }\left({ }^{\circ} \mathrm{C}\right) \& \\
\text { Time (h) }\end{array}$ & $\begin{array}{c}\text { Pressure } \\
\text { (MPa) }\end{array}$ & Solvent & & & & & \\
\hline $\mathrm{Ni}$ & 15 & $\mathrm{SiO}_{2}-\mathrm{Al}_{2} \mathrm{O}_{3}$ & $260-320$ & 2 & ethanol & alkaline lignin & $\begin{array}{c}\text { aromatics } \\
\text { monomer, } \\
\text { naphthalene, } \\
\text { phenolic } \\
\text { monomer }\end{array}$ & $\begin{array}{c}\text { conv. }(60 \%) \text { at } \\
300^{\circ} \mathrm{C} \\
\text { monomer yield: } \\
26.54 \%\end{array}$ & Batch & [104] \\
\hline $\mathrm{Ni}$ & 20 & $\begin{array}{l}\text { HZSM-5, } \\
\text { HBEA }\end{array}$ & $\begin{array}{c}250 \\
6\end{array}$ & 2 & n-hexadecane & organosolv lignin & $\begin{array}{l}\text { mono- and } \\
\text { bi-cyclic } \\
\text { naphthenes, } \\
\text { mono-cyclic } \\
\text { alcohols }\end{array}$ & $42 \pm 4 w t \%$ & Batch & [105] \\
\hline $\mathrm{Ni}$ & $\begin{array}{c}1.17 \times 10^{-5} \\
\mathrm{~mol} \mathrm{Ni}\end{array}$ & $@ \mathrm{SiC}$ & $\begin{array}{l}90 \\
20\end{array}$ & 0.6 & $\mathrm{H}_{2} \mathrm{O}, \mathrm{TBAB}$ & $\begin{array}{l}\text { benzyl phenyl } \\
\text { ether }\end{array}$ & $\begin{array}{l}\text { phenol and } \\
\text { toluene }\end{array}$ & $99 \%$ conversion & Batch & [106] \\
\hline $\begin{array}{l}\text { Raney } \\
\mathrm{Ni}\end{array}$ & - & - & $\begin{array}{c}300 \\
8\end{array}$ & 7 & $\begin{array}{c}\text { various protic, } \\
\text { aprotic polar, } \\
\text { aprotic } \\
\text { nonpolar } \\
\text { solvents }\end{array}$ & organosolv lignin & $\begin{array}{l}\text { various aromatic } \\
\text { \& naphthene } \\
\text { monomers }\end{array}$ & $\begin{array}{l}\text { 91\% conversion } \\
\text { (in } \\
\text { 2-propanol) } \\
\text { 86\% conversion } \\
\text { (in methanol) } \\
\text { 81\% conversion (in } \\
\text { methylcyclohexane) }\end{array}$ & & [62] \\
\hline $\begin{array}{l}\text { Raney } \\
\mathrm{Ni}\end{array}$ & - & - & $\begin{array}{l}120 \\
20\end{array}$ & - & formic acid & $\begin{array}{l}\text { enzymolysis } \\
\text { lignin }\end{array}$ & bio-oil & $\begin{array}{c}\text { bio-oil yield: } \\
58.11 \%\end{array}$ & Batch & [87] \\
\hline $\begin{array}{l}\text { Raney } \\
\mathrm{Ni}\end{array}$ & - & - & $\begin{array}{c}360 \\
3\end{array}$ & 7.5 & $\begin{array}{c}\text { supercritical } \\
\qquad \mathrm{H}_{2} \mathrm{O}\end{array}$ & organosolv lignin & $\begin{array}{l}\text { phenolic } \\
\text { compounds }\end{array}$ & $\begin{array}{c}\text { yield: } \\
1.3-8.0 \text { wt \% }\end{array}$ & Batch & [88] \\
\hline $\begin{array}{c}\text { Raney } \\
\mathrm{Ni}\end{array}$ & - & - & $\begin{array}{l}160-180 \\
3.5\end{array}$ & 2.0 & $\begin{array}{c}\text { dioxane } / \mathrm{H}_{2} \mathrm{O} \\
\mathrm{NaOH}\end{array}$ & $\begin{array}{c}\text { enzymolysis } \\
\text { lignin }\end{array}$ & oligomers & conv. $(82.3 \%)$ & Batch & [107] \\
\hline $\begin{array}{l}\text { Raney } \\
\mathrm{Ni}\end{array}$ & - & - & $\begin{array}{c}75 \\
6\end{array}$ & 0.1 & $\begin{array}{l}\text { aq. buffer } \\
\text { solution }\end{array}$ & guaiacol & cyclohexanol & $91 \%$ selectivity & Batch & [89] \\
\hline $\mathrm{Ni}-\mathrm{W}_{2} \mathrm{C}$ & 4 & $\mathrm{AC}$ & $\begin{array}{c}235 \\
4\end{array}$ & 6 & $\begin{array}{l}\text { ethylene } \\
\text { glycol }\end{array}$ & birch wood & $\begin{array}{l}\text { phenols (guaiacyl } \\
\text { propanol, } \\
\text { syringyl propanol, } \\
\text { guaiacyl propane, } \\
\text { syringyl propane) }\end{array}$ & $\begin{array}{c}46.5 \text { wt } \% \\
(5.0 \text { wt } \%, \\
9.6 \text { wt } \%, 5.4 \text { wt \%, } \\
18.2 \text { wt \%) }\end{array}$ & Batch & [108] \\
\hline Ni-WP & 2 & $\mathrm{AC}$ & $\begin{array}{c}280 \\
2\end{array}$ & 2 & water-ethanol & alkaline lignin & phenols & $\begin{array}{c}\text { yield: } 48.8 \mathrm{mg} / \mathrm{g} \\
\text { lignin }\end{array}$ & Batch & [109] \\
\hline $\mathrm{Ni}$ & $0.5 \mathrm{~mol}$ ratio & TiN & 125 & 1.2 & alcohol & phenyl ether & $\begin{array}{c}\text { aromatic } \\
\text { monomer, phenol }\end{array}$ & conv. (>99\%) & Batch & [110] \\
\hline
\end{tabular}


Table 5. Cont.

\begin{tabular}{|c|c|c|c|c|c|c|c|c|c|c|}
\hline \multirow[b]{2}{*}{ Cat. } & \multirow[b]{2}{*}{$\begin{array}{l}\text { Ni Loading } \\
\text { (wt \%) }\end{array}$} & \multicolumn{4}{|c|}{ Reaction Conditions } & \multirow[b]{2}{*}{ Substrate } & \multirow{2}{*}{ Major Products } & \multirow{2}{*}{$\begin{array}{c}\text { Max. } \\
\text { Performance } \\
\text { Obtained (\%) }\end{array}$} & \multirow{2}{*}{$\begin{array}{l}\text { Reactor } \\
\text { Type }\end{array}$} & \multirow[b]{2}{*}{ Ref } \\
\hline & & Support & $\begin{array}{l}\mathrm{T}\left({ }^{\circ} \mathrm{C}\right) \& \\
\text { Time (h) }\end{array}$ & $\begin{array}{c}\text { Pressure } \\
\text { (MPa) }\end{array}$ & Solvent & & & & & \\
\hline $\mathrm{Ni}$ & $6 \mathrm{mmol} \mathrm{Ni}$ & $\mathrm{TiN}$ & 125 & 2.5 & alcohol, THF & $\begin{array}{l}\text { benzyl phenyl } \\
\text { ether } \\
\text { Kraft lignin }\end{array}$ & $\begin{array}{l}\text { phenol \& toluene } \\
\text { aromatic } \\
\text { fragments }\end{array}$ & $\begin{array}{c}\text { conv. }(60 \%) \\
\text { yield: (71\% max.) }\end{array}$ & Continuous & [111] \\
\hline $\mathrm{Ni}-\mathrm{Mo}_{2} \mathrm{C}$ & 0.3 & HY & $\begin{array}{c}250 \\
4\end{array}$ & 4 & $\begin{array}{c}\mathrm{H}_{2} \mathrm{O} / \text { ethanol } \\
(\mathrm{v} / \mathrm{v}=1 / 1)\end{array}$ & corn stover lignin & $\begin{array}{l}\text { phenolic } \\
\text { monomers }\end{array}$ & yield: $37.3 \%$ & Batch & [112] \\
\hline NiMoS & 3 wt $\% \mathrm{NiO}$ & $\mathrm{Al}_{2} \mathrm{O}_{3}$ & $320-340$ & $\begin{array}{l}\text { ethanol } \\
\text { steam } \\
\text { reforming }\end{array}$ & ethanol & rice stalk & bio-oil & yield: $36 \%$ & Batch & [113] \\
\hline NiMoS & $\begin{array}{l}3.9 \text { wt \% } \\
\mathrm{NiO}\end{array}$ & - & 340 & 6.5 & 2-PrOH & Kraft lignin & $\begin{array}{l}\text { depolymerized } \\
\text { aromatics }\end{array}$ & $\begin{array}{c}\text { monomer yield: } \\
15 \%\end{array}$ & Continuous & {$[114]$} \\
\hline $\mathrm{Ni}-\mathrm{Fe}$ & 5 & $\mathrm{AC}$ & $\begin{array}{c}200 \\
6\end{array}$ & 2 & methanol & organosolv lignin & $\begin{array}{l}\text { aromatic } \\
\text { monomers }\end{array}$ & $\begin{array}{l}\text { monomer yield: } \\
23.2 \mathrm{wt} \%\end{array}$ & Batch & [115] \\
\hline $\mathrm{FeNiB}$ & $\begin{array}{c}\text { equal molar } \\
\text { ratio of Fe \& } \\
\mathrm{Ni}\end{array}$ & - & $\begin{array}{c}320 \\
2\end{array}$ & - & $\begin{array}{c}\text { ethanol } \\
\text { (supercritical) }\end{array}$ & $\begin{array}{l}\text { acetophenone, } \\
\text { lignin (Poplar) }\end{array}$ & $\begin{array}{l}\text { ethylbenzene } \\
\text { bio-oil }\end{array}$ & $\begin{array}{c}\text { conv. }(74 \%) \\
\text { select. }(84 \%)\end{array}$ & Batch & [116] \\
\hline $\mathrm{Ni}-\mathrm{Cu}$ & $\begin{array}{l}20 \text { wt } \% \mathrm{Ni} \\
20 \text { wt } \% \mathrm{Cu}\end{array}$ & H-Beta & $\begin{array}{c}330 \\
3\end{array}$ & - & isopropanol & Kraft lignin & $\begin{array}{l}\text { paraffins, } \\
\text { naphthenes, } \\
\text { phenolic } \\
\text { naphthenes, } \\
\text { aromatics } \\
\text { monomers }\end{array}$ & $\begin{array}{l}\text { bio-oil yield: } \\
98.80 \mathrm{wt} \% \\
\text { monomer yield: } \\
50.83 \mathrm{wt} \%\end{array}$ & Batch & [117] \\
\hline $\mathrm{Ni}-\mathrm{Cu}$ & $\begin{array}{c}\mathrm{Cu}: \mathrm{Ni}=3: 1 \\
10 \mathrm{~mol} \% \text { on } \\
\text { support }\end{array}$ & Ti-MCM-41 & $\begin{array}{c}260 \\
6\end{array}$ & 10 & heptane & guaiacol & cyclohexane & $\begin{array}{c}\text { conv. }(90.2 \%) \\
\text { select. }(51.2 \%)\end{array}$ & Batch & [118] \\
\hline $\mathrm{Ni}-\mathrm{Co}$ & $\mathrm{Ni}: \mathrm{Co}=1: 3$ & - & $\begin{array}{c}170 \\
6\end{array}$ & 2 & ethanol/ $\mathrm{H}_{2} \mathrm{O}$ & 2-phenoxy-1-pheny & $\begin{array}{c}\text { deoxygenated and } \\
\text { lethanbydrolysis } \\
\text { products }\end{array}$ & conv. $(85 \%)$ & Batch & [119] \\
\hline $\mathrm{Ni}-\mathrm{Al}$ & 50 & - & $\begin{array}{c}220 \\
3\end{array}$ & 2 (Ar) & $\mathrm{NaOH}(\mathrm{aq})$ & lignin (Poplar) & $\begin{array}{l}\text { cyclohexanol, } \\
\text { aromatics } \\
\text { monomers and } \\
\text { oligomers }\end{array}$ & $\begin{array}{l}\text { conv. }(86.8 \%) \\
\text { monomer yield: } \\
18.9 \%\end{array}$ & Batch & [120] \\
\hline $\mathrm{Pd}_{1} \mathrm{Ni}_{4}$ & $\begin{array}{c}\mathrm{Pd}: \mathrm{Ni}=1: 4 \\
\text { mol ratio, } 4 \\
\text { mol \% on } \\
\text { support }\end{array}$ & MIL-100(Fe) & $\begin{array}{c}130 \\
6\end{array}$ & - & $\mathrm{H}_{2} \mathrm{O}$ & $\begin{array}{c}\beta-\mathrm{O}-4 \text { lignin } \\
\text { model compound }\end{array}$ & $\begin{array}{l}\text { aromatic } \\
\text { monomers }\end{array}$ & conv. $(99 \%)$ & Batch & [121] \\
\hline
\end{tabular}


Table 5. Cont.

\begin{tabular}{|c|c|c|c|c|c|c|c|c|c|c|}
\hline \multirow[b]{2}{*}{ Cat. } & \multirow[b]{2}{*}{$\begin{array}{l}\text { Ni Loading } \\
\text { (wt \%) }\end{array}$} & \multicolumn{4}{|c|}{ Reaction Conditions } & \multirow[b]{2}{*}{ Substrate } & \multirow{2}{*}{ Major Products } & \multirow{2}{*}{$\begin{array}{c}\text { Max. } \\
\text { Performance } \\
\text { Obtained (\%) }\end{array}$} & \multirow{2}{*}{$\begin{array}{l}\text { Reactor } \\
\text { Type }\end{array}$} & \multirow[b]{2}{*}{ Ref } \\
\hline & & Support & $\begin{array}{l}\mathrm{T}\left({ }^{\circ} \mathrm{C}\right) \& \\
\text { Time }(\mathrm{h})\end{array}$ & $\begin{array}{l}\text { Pressure } \\
\text { (MPa) }\end{array}$ & Solvent & & & & & \\
\hline $\mathrm{Pd}_{1} \mathrm{Ni}_{7}$ & $\begin{array}{c}\mathrm{Pd}: \mathrm{Ni}=1: 7 \\
\text { mol ratio }\end{array}$ & - & $\begin{array}{c}100 \text { or } 130 \\
16\end{array}$ & $1 \mathrm{~atm}$ & $\begin{array}{l}\text { ionic liquid } \\
\text { [bmim]OTf }\end{array}$ & $\begin{array}{c}\alpha-\mathrm{O}-4 \& \beta-\mathrm{O}-4 \\
\text { lignin model } \\
\text { compound }\end{array}$ & $\begin{array}{c}\text { phenolic and } \\
\text { aromatics } \\
\text { monomers }\end{array}$ & conv. $(99 \%)$ & Batch & {$[122]$} \\
\hline $\mathrm{Pd}-\mathrm{Ni}$ & $\begin{array}{c}\text { Pd:Ni = 1:1 } \\
\text { mol ratio, } 2.5 \\
\text { mol \% on } \\
\text { support }\end{array}$ & $\mathrm{ZrO}_{2}$ & $\begin{array}{c}80 \\
6\end{array}$ & $\mathrm{NaBH}_{4}$ & ethanol & $\begin{array}{c}\beta-\mathrm{O}-4 \text { lignin } \\
\text { model compound }\end{array}$ & $\begin{array}{c}\text { phenyl alcohol, } \\
\text { phenol, } \\
\text { dehydroxylated } \\
\text { products }\end{array}$ & yield: (>99\%) & Batch & [123] \\
\hline $\mathrm{Rh}$ & $\begin{array}{c}\mathrm{Rh}: \mathrm{Ni}=1: 1 \\
(\mathrm{~mol}) \\
\mathrm{Ni}=4.4 \mathrm{wt} \%\end{array}$ & $\begin{array}{c}\text { masked } \\
\text { with } \mathrm{NiOx}\end{array}$ & $\begin{array}{l}\max 60 \\
40\end{array}$ & 1 & $\mathrm{H}_{2} \mathrm{O}$ & $\begin{array}{l}\text { 1-benzoxy-2- } \\
\text { methoxy-benzene }\end{array}$ & $\begin{array}{l}\text { hydrodeoxygenated } \\
\text { and hydrolysis } \\
\text { products }\end{array}$ & conv. $(100 \%)$ & Batch & {$[124]$} \\
\hline $\mathrm{Ru}-\mathrm{Ni}$ & $\mathrm{Ni}(5), \mathrm{Ru}(1)$ & NDC & $\begin{array}{c}230 \\
4\end{array}$ & 1 & $\mathrm{H}_{2} \mathrm{O}$ & guaiacol & $\begin{array}{l}\text { aromatics and } \\
\text { naphthene } \\
\text { monomers }\end{array}$ & $\begin{array}{l}\text { conv. }(69 \%) \\
\text { select. to benzene } \\
(24 \%) ; \text { phenol } \\
(59 \%) ; \\
\text { cyclohexane }(1 \%) ; \\
\text { cyclohexanol } \\
(10 \%)\end{array}$ & Batch & {$[125]$} \\
\hline $\mathrm{Ru}-\mathrm{Ni}$ & $\mathrm{Ni}(5), \mathrm{Ru}(5)$ & HZSM-5 & 240 & 0.2 & $\mathrm{H}_{2} \mathrm{O}$ & guaiacol & phenol & conv. $(\sim 90 \%)$ & Batch & [78] \\
\hline$(\mathrm{RuNiAlO})_{\mathrm{x}}$ & $\begin{array}{l}5 \mathrm{wt} \% \mathrm{Ru} \\
\text { on NiAlO }\end{array}$ & - & $\begin{array}{c}180 \\
6\end{array}$ & 7 & methanol & $\begin{array}{l}\text { Lignin } \\
\text { (Miscanthus } x \\
\text { giganteus) }\end{array}$ & $\begin{array}{l}\text { aromatic } \\
\text { monomers and } \\
\text { dimers }\end{array}$ & conv. $(\sim 85 \%)$ & Batch & {$[126]$} \\
\hline NiRuNiRhNiPd & $\begin{array}{c}\mathrm{Ni} \\
(85 \mathrm{~mol} \%)\end{array}$ & - & $\begin{array}{l}130 \\
1 / 12\end{array}$ & 1 & $\mathrm{H}_{2} \mathrm{O}$ & organosolv lignin & $\begin{array}{l}\text { aromatic } \\
\text { monomers }\end{array}$ & $\begin{array}{c}\text { yield: } \\
6.8 \text { wt \% (NiRu) } \\
3.6 \text { wt \% (NiRh) } \\
4.6 \text { wt \% (NiPd) }\end{array}$ & Batch & [127] \\
\hline $\mathrm{Ni}_{7} \mathrm{Au}_{3}$ & $\begin{array}{c}\mathrm{Ni}: \mathrm{Au}=7: 3 \\
\quad(\mathrm{~mol})\end{array}$ & - & $130 / 170,1 / 12$ & 1 & $\mathrm{H}_{2} \mathrm{O}$ & $\begin{array}{l}\text { 2-phenoxy-1- } \\
\text { phenylethanol \& } \\
\text { organosolv lignin }\end{array}$ & $\begin{array}{l}\text { aromatic } \\
\text { monomers }\end{array}$ & $\begin{array}{c}\text { conv. }(96 \%) \\
\text { select. }(76.4 \%)\end{array}$ & Batch & [71] \\
\hline $\mathrm{Ni}_{7} \mathrm{Au}_{3}$ & $\begin{array}{c}\mathrm{Ni}: \mathrm{Au}=7: 3 \\
(\mathrm{~mol})\end{array}$ & - & $100,0.5$ & 1 & $\mathrm{H}_{2} \mathrm{O}, \mathrm{NaOH}$ & $\begin{array}{l}\text { 2-phenoxy-1- } \\
\text { phenylethanol }\end{array}$ & $\begin{array}{l}\text { phenol and } \\
\text { cyclohexanol }\end{array}$ & conv. $(>95 \%)$ & Batch & {$[128]$} \\
\hline $\mathrm{NiAg}$ & $\begin{array}{c}\mathrm{Ni}: \mathrm{Ag}=8: 2 \\
\text { (pre'ion } \\
\text { ratio), } 0.022 \\
\text { mol on } \\
\text { support }\end{array}$ & $\mathrm{SiO}_{2}$ & $\begin{array}{c}130 \\
1\end{array}$ & 1 & $\mathrm{H}_{2} \mathrm{O}$ & $\begin{array}{l}\text { 2-phenoxy-1- } \\
\text { phenylethanol }\end{array}$ & $\begin{array}{l}\text { phenol and } \\
\text { cyclohexanol }\end{array}$ & conv. $(95 \%)$ & Batch & [129] \\
\hline
\end{tabular}


Using $\mathrm{EtOH} / \mathrm{H}_{2} \mathrm{O}$ as solvent and $\mathrm{NaBH}_{4}$ as the hydrogen source, Ni on carbon black (CB) could convert benzyl phenyl ether into toluene and phenol in nearly quantitative yield ( 99\%) under mild reaction conditions $\left(80^{\circ} \mathrm{C}\right)$, in which the yield is higher than with $\mathrm{Ni} / \mathrm{AC}$ and other noble metal/AC catalysts. It should be noted that although the BET specific surface area of $C B$ is much lower than $A C$ $\left(97 \mathrm{~m}^{2} \mathrm{~g}^{-1}\right.$ vs. $\left.998 \mathrm{~m}^{2} \mathrm{~g}^{-1}\right)$, the vol \% of adsorption of $\mathrm{H}_{2} \mathrm{O}$ and $\mathrm{EtOH}$ of $\mathrm{CB}$ is much higher than $\mathrm{AC}(0.6$ and 0.74 vs. 0.18 and 0.63$)$. Moreover, $C B$ has a much lower electrical resistance than AC (1.8 Ohm vs. $1913.3 \mathrm{Ohm}$ ), which should facilitate the hydrogen spillover and $\mathrm{H}$ atoms activation from the $\mathrm{Ni}$ particle to the CB support (as shown in Figure 17).

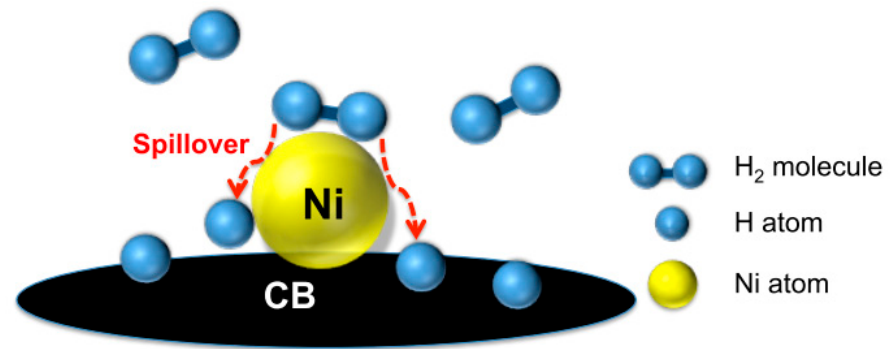

Figure 17. Proposed mechanism for hydrogen spillover on Ni/CB catalyst [93].

Besides changing different supports, lignin can also be modified structurally in order to facilitate lignin depolymerization [95]. It was reported that using $\mathrm{Ni} / \mathrm{C}$ and methanol-water co-solvent (6:4) system could first etherify the $\mathrm{C}_{\alpha}-\mathrm{OH}$ group of the lignin $\beta-\mathrm{O}-4$ structure under $\mathrm{H}_{2}$ atmosphere. This in turn break the hydrogen bonding between $\mathrm{C}_{\beta}-\mathrm{O}$ oxygen and the $\mathrm{C}_{\alpha}-\mathrm{OH}$ proton to assist the $\mathrm{C}_{\beta}$-O cleavage. Thus, beech sawdust could be converted to various phenolic alcohols such as syringyl-propanol, propyl-syringol, guaiacyl-propanol, etc. with a total of $51.4 \%$ conversion yield.

Lignosulfonate obtained from sulfite pulping processes is also one of the important sources of lignin for valorization. However, the sulfur content could be problematic because of sulfur-poisoning to catalysts. In a series of supported Ni catalysts for the hydrogenolysis of lignosulfonate, it has been postulated that $\mathrm{H}_{2}$ was first dissociated on the $\mathrm{Ni}(0)$ metal sites to form active $\mathrm{H}^{*}$, followed by the hydrogenation of the aryl-alkyl bond and alcoholic bonds to convert lignosulfonate to phenols. At the same time, the C-S bonds of lignosulfonate are also decomposed on the $\mathrm{Ni}(0)$ metal sites to form metastable nickel sulfides. Finally, the $\mathrm{H}^{*}$ combines with nickel sulfides to regenerate $\mathrm{Ni}(0)$ and elimination of $\mathrm{H}_{2} \mathrm{~S}$ and the catalytic cycles are completed [92].

The carbon support can also be modified to increase the catalytic activity of hydrogenolysis [98,99]. Doping the carbon support with electron donor atoms such as nitrogen should lead to (1) reduced work function of the support; (2) enhanced partial electron transfer between Ni and the support; (3) increased chemically active sites; (4) increased Ni particle dispersion. Thus, it has been shown that Ni-NDC (nitrogen doped carbon) enhanced the catalytic hydrogenolysis of lignin compared with undoped carbon supports [98]. Using NiMgAl layered double hydroxides and lignosulfonate to prepare the $\mathrm{Ni}$ metal catalyst supported on $\mathrm{MgAl}$ modified carbon support, the $3 d$ electron distribution of surface layer $\mathrm{Ni}$ can be altered to promote highly selective $\mathrm{C}-\mathrm{O}$ bond cleavage [99], while the $\mathrm{Ni} / \mathrm{C}$ catalysts only showed high conversion but lower monomer selectivity and the mixed oxide $\mathrm{Ni} / \mathrm{MgAlO}$ showed little or no activity.

$\mathrm{Ni}$ supported on acidic supports such as zeolites and silicates with both Brønsted and Lewis acidity are active catalysts for lignin hydrogenolysis by promoting dealkylations and deacylations and minimizing repolymerizations $[100,101]$. With suitable pore size and well-ordered pore structure, SBA-15 can effectively suppress repolymerization, with $81.4 \%$ liquefaction yield and $21.9 \mathrm{wt} \%$ monomer yields. No char and least repolymerization were observed when ethanol was being used as the solvent, which was attributed to the fact that ethanol can stabilize highly reactive phenolic intermediates and suppress the reaction between formaldehyde and the monomers to form large molecular weight oligomers. The importance of pore size of zeolite to product selectivity had further been demonstrated 
by Lercher et al [105]. As shown in Figure 18, when HBEA was used instead of HZSM-5 as the zeolite supports for Ni metal, higher selectivities were obtained for bicyclic products formed by alkylation during the HDO of phenolic monomers. The relatively smaller pore size of HZSM-5 hindered the alkylation thus leading to the lower selectivity of bicyclic products. With suitable tuning of the surface area and the pore size, the hierarchical (micro-meso pore structures) Ni@SiC catalyst (surface are $=527 \mathrm{~m}^{2} \mathrm{~g}^{-1}$ ) was proven to be more catalytically active and more selective to aromatics without hydrogenation of aromatic rings during hydrolysis of benzyl phenyl ether, compared with the respective microspore (surface area $=326 \mathrm{~m}^{2} \mathrm{~g}^{-1}$ ) and mesoporous (surface area $=202 \mathrm{~m}^{2} \mathrm{~g}^{-1}$ ) Ni@SiC catalysts [106]. Recently, microwave irradiation technology has been developed to depolymerization of lignins into simple phenolic and monomeric products by using the hydrogen-donating solvent (formic acid) over Ni-based catalyst [102,103]. Toledano et al. reported that the yield of oil could be reached $37 \mathrm{wt} \%$ for the depolymerization of organosolv lignin over $10 \% \mathrm{Ni} / \mathrm{SBA}-15$ catalyst at $100 \mathrm{~W}$ microwave power for $30 \mathrm{~min}$ and the main products were desaspidinol, syringaldehyde, and syringol.

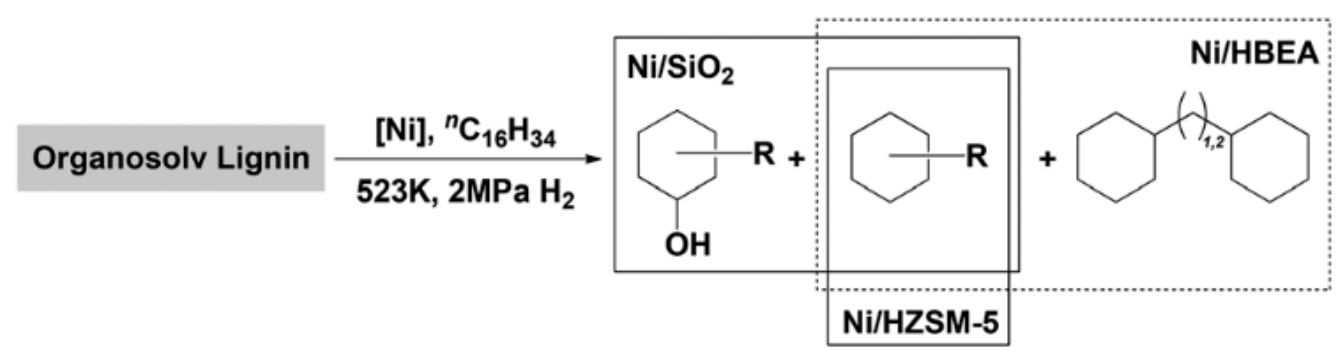

Figure 18. Product distributions in the organosolv lignin deconstruction over $\mathrm{Ni} / \mathrm{SiO}{ }_{2}, \mathrm{Ni} / \mathrm{HZSM}-5$, and Ni/HBEA catalysts [105].

\subsection{Ni-Based Bimetallic Catalysts for Hydrogenolysis of Lignin}

Several bimetallic Ni catalysts, resulting from the combination of $\mathrm{Ni}$ with other non-precious transition metals in the same row, namely, Ni-Fe/AC, Ni-Co and $\mathrm{Fe}-\mathrm{Cu}$, with potential to display "synergistic effects" [131], have been found to preserve better the aromatic rings rather than leading to their hydrogenation. The supports that were found to promote the activity for these catalysts are generally zeolite and activated carbon materials with high specific surface area, and the common metal oxide supports such as $\mathrm{Al}_{2} \mathrm{O}_{3}, \mathrm{SiO}_{2}, \mathrm{NbOPO}_{4}$, and $\mathrm{CeO}_{2}$ have been found to have less promoting effects due to limited specific surface area and weaker acidic properties $[132,133]$. When the ratio of $\mathrm{Ni}$ and Fe is 1:1, alloy structure was formed and the monomer yield is much higher than that of Ni/AC and $\mathrm{Fe} / \mathrm{AC}(\mathrm{Ni}-\mathrm{Fe} / \mathrm{AC}=20.3 \% ; \mathrm{Ni} / \mathrm{AC}=12.54 \% ; \mathrm{Fe} / \mathrm{AC}=6.3 \%)$. Also, at $400{ }^{\circ} \mathrm{C}$, the $\mathrm{Fe}$ can be much more easily reduced to $\mathrm{Fe}^{0}$ for $\mathrm{Ni}-\mathrm{Fe} / \mathrm{AC}$. The same phenomenon was observed for FeNiB catalyst during the hydrogenolysis of acetophenone, where $74 \%$ conversion yield was observed $(\mathrm{NiB}=23 \%$, $\mathrm{FeB}=42 \%$ ) [116]. Compared with other zeolite supports such as HZSM-5, MAS-7, MCM-41, and SAPO-11, H-Beta was found to have the highest acidity $(1.3 \mathrm{mmol} / \mathrm{g})$. Using isopropanol as the solvent, highest cycloalkanes yield (40.39\%) was obtained for $\mathrm{Ni}-\mathrm{Cu} / \mathrm{H}-\mathrm{Beta}$ catalyst [117]. The incorporation of Ti metal into the MCM silicate support materials for $\mathrm{Ni}-\mathrm{Cu}$ has further increased the average pore size, the number of acidic sites, and enhanced the redox properties, thus both the reactivity and selectivity of the HDO of guaiacol to cyclohexane have been both increased significantly [118]. While the increase in conversion yields are obvious for $\mathrm{Ni}-\mathrm{Fe} / \mathrm{AC}$ and $\mathrm{Ni}-\mathrm{Cu}$, the "synergistic effect" may not be that obvious for the Ni-Co@C catalysts (@C: coated with graphene layers). Instead, the catalysts in the Ni-Co series afford similar conversion yields but have been found to cause various degree of hydrogenolysis and HDO, while Ni@C prefers to undergo hydrogenolysis and Co@C prefers to under hydrogenation reactions (as shown in Figure 19) [119]. 


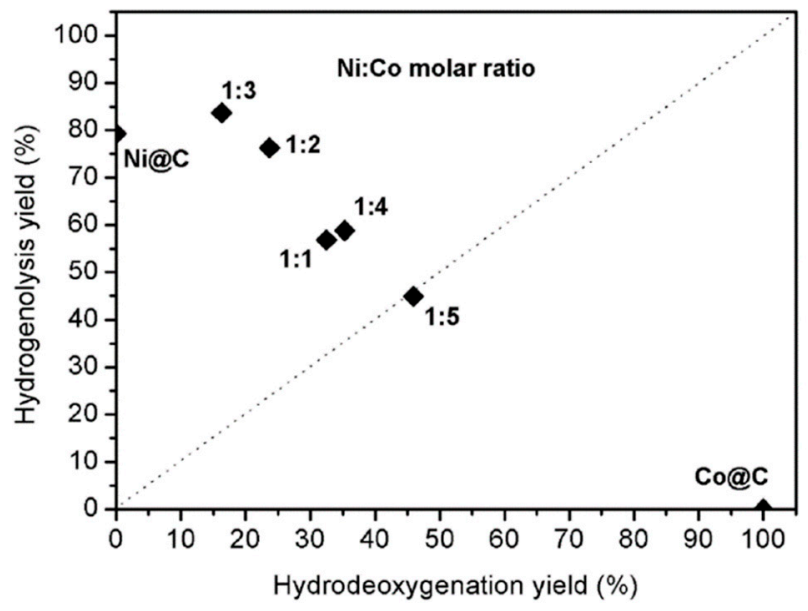

Figure 19. The correlation between the reaction selectivity and the composition of bimetallic nanoparticles for Ni@C, Co@C, and Ni-Co@C [119].

Tungsten carbide catalysts, which are also known as the semiconducting supports [134], when promoted with $\mathrm{Ni}$, have comparable activity and selectivity with $\mathrm{Pt} / \mathrm{Al}_{2} \mathrm{O}_{3}$ and $\mathrm{Ru} / \mathrm{C}$ for the conversion of cellulose to polyols [135]. The activity has been shown to be more prominent when activated carbon was used as the support instead of $\mathrm{Al}_{2} \mathrm{O}_{3}$, where the more active phase $\mathrm{W}_{2} \mathrm{C}$ can be formed with activated carbon and the less active but more thermally stable WC was formed with $\mathrm{Al}_{2} \mathrm{O}_{3}$ support. There is an obvious synergistic effect between $\mathrm{Ni}$ and $\mathrm{W}_{2} \mathrm{C}$ support, and the effect is even more pronounced during lignin hydrogenolysis [108], while no synergistic effect was observed for noble metal and $\mathrm{W}_{2} \mathrm{C}$ support. Thus, lignin can be converted selectively to monophenols with a yield of $46.5 \%$, based on lignin. Recently, the phosphorus and carbon analogy has been extensively studied in many areas, such as in main group chemistry and in the field of catalysis [136]. As such, WP/AC has also been explored in the hydrogenolysis of lignin. It was found that WP/AC gives the highest phenol yield, when compared with $\mathrm{WP} / \mathrm{SiO}_{2}$. When $\mathrm{WP} / \mathrm{AC}$ was doped with Ni metal, however, yield was decreased although the selectivity to phenols was increased (WP/AC $=51.7 \%$, Ni-WP/AC $=73.1 \%$ ). The reaction may be due to the re-polymerization of small molecules to form fragments lying within a $\mathrm{m} / \mathrm{z}$ range of 701-1040, as observed by mass spectrometry [109].

The Mott-Schottky effect has been further explored to demonstrate the ability of semiconducting supports in heterogeneous catalysts to modify the electron density and hence the activity of the supported metal catalysts. Ni supported by TiN had been tested towards hydrogenolysis of lignin-derived model compounds such as aryl ethers $[110,111]$. Again, the conversion and selectivity to aromatic monomers had been increased significantly compared with pure TiN and $\mathrm{Ni}$ when used for catalytic hydrogenolysis of $\alpha-\mathrm{O}-4$ and $\beta-\mathrm{O}-4$ model compounds. However, when reaction temperature was increased from $125^{\circ} \mathrm{C}$ to $150{ }^{\circ} \mathrm{C}$, hydrogenation of aromatic rings started to be observed. The authors explained that there may be electron transfer process from $\mathrm{Ni}$ atoms to the TiN support. The Ni and TiN are tightly bonded to each other, and the electrons flowed from the less noble (Ni) to the relatively more noble (TiN) supports in order to equilibrate the Fermi levels. As a result, the oxygen of ether linkages coordinated to the electron-deficient Ni more effectively, thus facilitating the hydrogenation reactions and accelerating the hydride transfer to the aromatic ring during reductive elimination.

With the success of these Ni doped transition metal catalysts, attention was then turned to developing other similar catalysts such as the $\mathrm{Ni}-\mathrm{Mo}_{2} \mathrm{C}$ [112]. An added bonus of $\mathrm{Mo}_{2} \mathrm{C}$ compared with $\mathrm{W}_{2} \mathrm{C}$ was that high surface area and bulk catalyst can be prepared for $\mathrm{Mo}_{2} \mathrm{C}$ without any support materials. With Ni doping, monomer yield of hydrogenolysis of corn stover lignin by the $\mathrm{Ni}-\mathrm{Mo}_{2} \mathrm{C}$ had been significantly increased $\left(37.3 \%\right.$ ) compared with pure $\mathrm{Mo}_{2} \mathrm{C}$ catalyst. The increases in metallic sites and the decreases in acidic sites have both minimized the re-polymerization reaction and coking. 
However, mixing the $\mathrm{Mo}_{2} \mathrm{C}$ catalyst with zeolitic co-catalysts as physical mixture such as $\mathrm{HY}$ and $\mathrm{H}$-beta does not necessarily bring about synergistic effect on the overall monomer yield, as in the case observed for $\mathrm{Ru} / \mathrm{Al}_{2} \mathrm{O}_{3}$ catalyst [137]. The reaction may be due to the excessive coupling reactions occurred on the acidic sites of zeolite surface while the metallic sites of Mo are too far away from the zeolite surface.

Since the discovery of redox neutral C-O bond cleavage using Pd/C catalyst [121], several Pd-Ni catalysts with different $\mathrm{Pd}$ :Ni ratio had been demonstrated to exhibit hydrogenolysis of lignin derived model compound without the use of hydrogen gas [121]. Both the synergistic effects between the metal nanoparticles and between the metal and the metal organic framework (MOF) supports are crucial factors to optimal catalytic performance. Without hydrogen source, $\mathrm{Pd}_{1} \mathrm{Ni}_{4}(\mathrm{Pd}: \mathrm{Ni}=1: 4)$ demonstrated a $80 \%$ conversion yield for the hydrogenolysis of 2-phenoxy-1-phenethanol and $90 \%$ selectivity to phenol and acetophenone. With using MOF such as MIL-100(Fe), 99\% conversion and $>95 \%$ selectivity can be achieved. It should be noted that Pd/MIL-100(Fe) only gave $77 \%$ conversion yield and $71 \%$ selectivity to phenol and acetophenone, which further demonstrated the "synergistic effect" of bimetallic metal complexes on catalytic hydrogenolysis. The highly porous structure, water stability and strong Lewis acidity has further promoted the $\beta-\mathrm{O}-4$ cleavage. Using ionic liquid such as [bmim]OTf as the reaction media, the $\alpha-\mathrm{O}-4$ can also be cleaved which may be due to the enhanced non-covalent interaction and enhanced acidity of the methylene proton of the $\alpha-\mathrm{O}-4$ bonds [122].

The "synergistic effect" was even more prominent for Ru-Ni bimetallic catalyst supported on HZSM-5. Ru-Ni/HZSM exhibited the highest activity towards hydrogenolysis of guaiacol $\left(118 \mathrm{mmol} \mathrm{g}^{-1} \mathrm{~h}^{-1}\right)$, which is four times higher than Ru/HZSM-5 and for Ni/HZSM-5 only $3.2 \mathrm{mmol} \mathrm{g}^{-1}$ $\mathrm{h}^{-1}$ was attained [78]. It was found that although $\mathrm{Ru}-\mathrm{Ni}$ was not in the alloy form, the $\mathrm{Ru}$ and $\mathrm{Ni}$ nanoparticles were strongly interacting with each other. Ru effectively dissociated the $\mathrm{H}_{2}$ gas to form $\mathrm{H}^{\bullet}$ radicals, in which the radicals were transferred to the adjacent inert Ni sites. The transfer length between $\mathrm{Ru}$ and $\mathrm{Ni}$ nanoparticles were found to be closely related to the $\mathrm{C}-\mathrm{O}$ bond cleavage activity, i.e., the shorter the length, the highest the activity.

As mentioned above, Ni-NDC (nitrogen doped carbon) enhanced the catalytic hydrogenolysis of lignin compared with undoped carbon supports [98]. This was also observed for the Ru-Ni bimetallic catalyst. The yield, conversion, and selectivity to benzene and phenol versus cyclohexane and cyclohexanol had been increased for $1 \% \mathrm{Ru}-5 \% \mathrm{Ni}-\mathrm{NDC}$ for the hydrogenolysis of guaiacol compared with $1 \% \mathrm{Ru}-5 \% \mathrm{Ni} / \mathrm{AC}$ [125]. The reason was not only due to the electron rich nitrogen atoms led to enhanced interaction between the metals and the supports but also the retaining of the metal particles. As a result, aromatics selectivity was enhanced.

The last precious metal in the 5th row that was found to form bimetallic complexes for lignin hydrogenolysis is the Rh metal [124,127]. Yan et al. had compared the activities of a series of NiM $(\mathrm{M}=\mathrm{Ru}, \mathrm{Rh}$, and $\mathrm{Pd})$ towards the lignin hydrogenolysis [127]. While it was found that the reduction of Fe was facilitated by the incorporation of $\mathrm{Ni}$ for Ni-Fe/AC complexes, the incorporation of $15 \% \mathrm{Ru}$ enhanced the reduction rate of $\mathrm{Ni}$ for $\mathrm{Ni}_{85} \mathrm{Ru}_{15}$ complexes. The presence of $\mathrm{Ni}$ in $\mathrm{Ni}_{85} \mathrm{Ru}_{15}$ complexes can also suppress the hydrogenation of aromatic ring. Instead of enhancing synergistic effects between metals, Yan's group had also successfully masked the Rh nanoparticles with hydrogenation-inactive $\mathrm{NiO}_{x}$ species, thus, the selectivity of the hydrogenolysis reaction of 1-benzoxy-2-methoxy-benzene towards aromatics monomers can be maximized [124].

Going down to the 6th row of the periodic tables, $\mathrm{Ni}-\mathrm{Au}$ and Ni-Ag bimetallic catalysts were found. It was known that monometallic Au catalysts exhibits no activity towards lignin hydrogenolysis and that $\mathrm{Ni}$-Au bimetallic catalysts had reduced activity in many catalytic reactions compared with Ni catalysts, such as methane steam reforming [138] and hydrogenation of dinitrobenzene [139]. Surprisingly, the $\mathrm{Ni}_{7} \mathrm{Au}_{3}$ bimetallic catalyst exhibited a three times higher activity than using monometallic Ni catalyst, in which $14 \mathrm{wt} \%$ of monomer yield can be obtained for organosolv lignin. The reason for the enhanced activity may be due to the unique electronic state of $\mathrm{Ni}$ in the $\mathrm{Ni}_{7} \mathrm{Au}_{3}$. Au acts as electron donor to make the $\mathrm{Ni}$ atoms become more electron enriched, which in turn enhanced the 
lignin hydrogenolysis [71]. The conversion yields were even more pronounced if a base such as $\mathrm{NaOH}$ was added with high selectivity to aromatic monomers [128], which prevented the adsorption of the aromatic ring on the catalyst surface. In contrast, the Ni-Ag catalysts had only been scarcely studied in a few catalytic reactions, such as hydrocarbon reforming [140] and hydrogen production using hydride compounds [141]. "Synergistic effect" was also observed for Ni-Ag catalysts towards lignin hydrogenolysis [129], leading to enhanced cleavage of C-O bonds, high conversion (95\%) and high selectivity $(90 \%)$ to aromatic monomers which were superior to the conversion by $\mathrm{Ni}$ and $\mathrm{Ag}$ monometallic catalysts respectively. The reason of the enhanced effect may be due to the segregation of surface $\mathrm{Ni}$ atom by the inactive $\mathrm{Ag}$ atoms, which also inhibited the adsorption of aromatic rings to the active surfaces.

\section{Conclusions \& Future Prospect}

Monometallic and bimetallic Ni metal catalysts had been extensively explored for the lignin valorizations to renewable chemicals and fuels over the past decade, with the use of various supports (undoped and doped activated carbons, carbon nanotubes, zeolites and metallated zeolites, metal nitride, oxides, phosphides) and various precious and non-noble metals ( $\mathrm{Fe}, \mathrm{Co}, \mathrm{Cu}, \mathrm{Al}, \mathrm{Pd}, \mathrm{Pt}, \mathrm{Rh}$, $\mathrm{Ru}, \mathrm{Re}, \mathrm{Nb}, \mathrm{Mo}, \mathrm{Au}, \mathrm{Ag}$ ). This review briefly introduced the representative examples in catalytic conversion of lignin into valuable products via the pyrolysis, HDO, and hydrogenolysis processes over Ni-based catalyst in recent achievements. In order to facilitate the commercialization of lignin to fuels and chemicals process, first, much effort has to be put on the research on direct converting lignin in continuous flow manners as higher throughput can be obtained compared with batch settings. Second, the designed catalysts should be able to maximize the selectivity to C-O bond hydrogenolysis products, and to decrease the thermodynamically favorable aromatic hydrogenation products. Finally, re-polymerization reactions of monomer products should be suppressed.

Compared with cellulose and hemicellulose valorizations, the commercialization and industrial scale-up examples of lignin valorizations to chemicals and fuels are relatively less explored. Several commercial cellulosic ethanol plants have been either on operation or under construction, such as DuPoint (corn stover to ethanol), Gulf Coast Energy (wood waste to ethanol), Fulcrum BioEnergy (municipal solid waste to ethanol), etc. and the blending of ethanol to gasoline has been a popular strategy to help reduce carbon emission in US. While lignins are still considered to be a waste in the pulp and paper industry, companies like the Borregaard Biorefinery has taken a great step towards lignin valorization, in which they make use of lignin as an additive in concrete production and in the production of flavoring agent vanillin. As the construction of the first lignin to biofuel plant is yet to be completed (Preem \& RenFuel Co. Ltd., Sweden), more research outcomes on the direct valorization of lignin using $\mathrm{Ni}$ and related efficient catalysts are expected to be published. In addition, there are several prospects of the future applications of Ni-based catalysts in conversion of lignin into value-added chemicals.

A How to achieve the lignocellulosic valorizations directly?

Although the research of the catalytic conversion of lignin model compounds provides an insight into the lignin valorizations, the utilization of real lignin is still a challenge due to the complex structure and composition. In addition, the typical biomass includes lignin, cellulose, and hemicellulose. Catalytic conversion of lignocellulosic is a promising strategy to make full use of bioenergy. However, the complex physiochemical features of lignocellulosic limits the chemical conversion in one-pot to some extent. Although scientists and engineers has made great efforts on this research area and developed a lot of cost-effective catalysts due their excellent hydrogenation activities to convert lignocellulosic into fuels and chemicals, including Raney $\mathrm{Ni}$ [142-145], $\mathrm{Ni}-\mathrm{Al}_{2} \mathrm{O}_{3}$ [146], Ni/C [147,148], $\mathrm{Ni}-\mathrm{W}_{2} \mathrm{C} / \mathrm{AC}$ [108], etc., the efficiency and stability of catalysts have still great room for improvement. Besides, to deoxygenate lignin efficiently, addition of hydrogen-sufficient feedstock, such as waste materials (plastics, rubber), coal tar, etc., into the catalytic process of lignin may benefit from producing value-added products from lignin, which could concomitantly increase the production of aromatic 
hydrocarbons and reduce environmental impacts. In addition, it is a promising strategy to enhance the lignin valorizations through introducing some green and environmental friendly solvents, such as water, ionic liquid, hydrogen-donor solvent, in which using the harsh reaction conditions can be avoided (high temperature and high $\mathrm{H}_{2}$ pressure) and the atomic economy can be improved.

B How to design robust and stable Ni-based catalysts?

Robust and stable catalysts play a vital role in the lignin valorizations. Due to the high oxygen content of lignin, the development of highly active and stable catalysts is necessary in the upgrading of lignin. Recently, bifunctional catalysts containing metal active sites and acid sites are widely designed for the upgrading of lignin, such as $\mathrm{Ni} / \mathrm{Al}_{2} \mathrm{O}_{3}, \mathrm{Ni} / \mathrm{HZSM}-5, \mathrm{Ni} / \mathrm{ZrO}_{2}$, etc. Among these, $\mathrm{Nb}_{2} \mathrm{O}_{5}$, is an excellent solid acid with abundant acid sites and water resistance, and has also been widely studied in recent years. In addition, the single-phase $\mathrm{Ni}_{2} \mathrm{Si}_{2} / \mathrm{SiO}_{2}-\mathrm{Al}_{2} \mathrm{O}_{3}$ catalyst has been designed by interstitial modification with earth-abundant silicon, in one-step chemical vapor deposition. The metal active sites and the acid properties of support has been tuned, enhancing the stability and the selectivity towards the HDO of lignin-derived aryl ethers to renewable bio-oils [149]. Therefore, the development of green, high efficiency, and stable catalysts through designing of metal activity sites and tuning the acid of support is the key factor in future research of the nickel catalytic transformation of lignin.

Author Contributions: Review on Pyrolysis, X.C.; Review on Hydrodeoxygenation, W.G.; General Direction and Review on Hydrogenolysis, C.-W.T.; General Direction and Perspective, H.H. \& C.L.

Funding: This research was funded by the National Key Research \& Development Program of China (2016YFB0600305) and the Hong Kong University Grants Committee-Faculty Development Scheme (UGC/FDS25/E09/17).

Conflicts of Interest: The authors declare no conflict of interest.

$\begin{array}{ll}\text { Abbreviations } \\ \text { W/F } & \text { weight of catalyst: feedgas flowrate } \\ \text { CEL } & \text { cellulolytic enzyme lignin } \\ \text { HL } & \text { hydrolysis lignin } \\ \text { BTEX } & \text { benzene, toluene, ethylbenzene \& xylene } \\ \text { IS } & \text { iron slag } \\ \text { DFT } & \text { density functional theory } \\ \text { SD lignin } & \text { soda pulping } \\ \text { SAQ lignin } & \text { soda anthraquinone pulping } \\ \text { SEH lignin } & \text { steam explosion pre-treatment followed by enzymatic hydrolysis } \\ \text { SCW } & \text { supercritical water } \\ \text { WGS } & \text { water gas shift reaction } \\ \text { OSR } & \text { oxidative steam reforming } \\ \text { CB } & \text { carbon black } \\ \text { AC } & \text { activated carbon } \\ \text { GGGE } & \text { guaiacyl glycerol- } \beta \text {-guaiacyl ether } \\ \text { NDC } & \text { nitrogen doped carbon } \\ \text { LDH } & \text { layered double hydroxides } \\ \text { ASA } & \text { amorphous silica-alumina } \\ \text { HDO } & \text { hydrodeoxygenation } \\ \text { HYD } & \text { hydrogenation } \\ \text { CTH } & \text { catalytic transfer hydrogenation } \\ \text { MOF } & \text { metal organic framework }\end{array}$




\section{References}

1. Rada, E.C.; Ragazzi, M.; Torretta, V.; Castagna, G.; Adami, L.; Cioca, L.I. Circular economy and waste to energy. AIP Conf. Proc. 2018, 1968, 030050.

2. Vandecasteele, C. The role of Waste-to-energy in the circular economy. In Proceedings of the 18th ERSCP (European Round table on Sustainable Consumption and Production) Conference, Skiathos, Greece, 1-5 October 2017.

3. Anastas, P.T.; Warner, J.C. Green Chemistry: Theory and Practice; Oxford University Press: New York, NY, USA, 1998.

4. Metal Prices Per Kilogram. 2019. Available online: https://www.dailymetalprice.com/ (accessed on 25 April 2019).

5. Nuss, P.; Eckelman, M.J. Life cycle assessment of metals: a scientific synthesis. PLoS ONE 2014, 9, e101298. [CrossRef] [PubMed]

6. Zakzeski, J.; Bruijnincx, P.C.A.; Jongerius, A.L.; Weckhuysen, B.M. The Catalytic Valorization of Lignin for the Production of Renewable Chemicals. Chem. Rev. 2010, 110, 3552-3599. [CrossRef] [PubMed]

7. Pandey, M.P.; Kim, C.S. Lignin Depolymerization and Conversion: A Review of Thermochemical Methods. Chem. Eng. Technol. 2011, 34, 29-41. [CrossRef]

8. Mu, W.; Ben, H.; Ragauskas, A.; Deng, Y. Lignin Pyrolysis Components and Upgrading—Technology Review. Bioenergy Res. 2013, 6, 1183-1204. [CrossRef]

9. Ben, H.; Ragauskas, A.J. Pyrolysis of Kraft lignin with additives. Energy Fuels 2011, 25, 4662-4668. [CrossRef]

10. Collard, F.-X.; Blin, J.; Bensakhria, A.; Valette, J. Influence of impregnated metal on the pyrolysis conversion of biomass constituents. J. Anal. Appl. Pyrol. 2012, 95, 213-226. [CrossRef]

11. Geng, J.; Wang, W.L.; Yu, Y.X.; Chang, J.M.; Cai, L.P.; Shi, S.Q. Adding nickel formate in alkali lignin to increase contents of alkylphenols and aromatics during fast pyrolysis. Bioresour. Technol. 2017, 227, 1-6. [CrossRef]

12. Zheng, Y.; Wang, F.; Yang, X.; Huang, Y.; Liu, C.; Zheng, Z.; Gu, J. Study on aromatics production via the catalytic pyrolysis vapor upgrading of biomass using metal-loaded modified H-ZSM-5. J. Anal. Appl. Pyrol. 2017, 126, 169-179. [CrossRef]

13. Milovanovic, J.; Stensrød, R.; Myhrvold, E.; Tschentscher, R.; Stöcker, M.; Lazarevic, S.; Rajic, N. Modification of natural clinoptilolite and ZSM-5 with different oxides and studying of the obtained products in lignin pyrolysis. J. Serb. Chem. Soc. 2015, 80,717-729. [CrossRef]

14. Paysepar, H.; Rao, K.T.V.; Yuan, Z.; Shui, H.; Xu, C. Improving activity of ZSM-5 zeolite catalyst for the production of monomeric aromatics/phenolics from hydrolysis lignin via catalytic fast pyrolysis. Appl. Catal. A 2018, 563, 154-162. [CrossRef]

15. Ma, T.; Liu, Y.; Yu, H. Catalytic characteristics of pyrolysis volatile matter from biomass/biomass components on a novel Ni-based catalyst supported by iron slag. J. Renew. Sustain. Ener. 2017, 9, 063101. [CrossRef]

16. Naron, D.R.; Collard, F.X.; Tyhoda, L.; Görgens, J.F. Production of phenols from pyrolysis of sugarcane bagasse lignin: Catalyst screening using thermogravimetric analysis-Thermal desorption-Gas chromatography-Mass spectroscopy. J. Anal. Appl. Pyrol. 2019, 138, 120-131. [CrossRef]

17. Lee, H.; Cha, J.; Park, Y.-K. Catalytic co-pyrolysis of Kraft lignin with refuse-derived fuels using Ni-loaded ZSM-5 type catalysts. Catalysts 2018, 8, 506. [CrossRef]

18. Shafaghat, H.; Jae, J.; Jung, S.-C.; Jeon, J.-K.; Ko, C.H.; Park, Y.-K. Effect of methane co-feeding on product selectivity of catalytic pyrolysis of biomass. Catal. Today 2018, 303, 200-206. [CrossRef]

19. Jiang, Y.T.; Li, Z.; Tang, X.; Sun, Y.; Zeng, X.H.; Liu, S.J.; Lin, L. Depolymerization of cellulolytic enzyme lignin for the production of monomeric phenols over Raney ni and acidic zeolite catalysts. Energy Fuels 2015, 29, 1662-1668. [CrossRef]

20. Wu, C.; Wang, Z.; Dupont, V.; Huang, J.; Williams, P.T. Nickel-catalysed pyrolysis/gasification of biomass components. J. Anal. Appl. Pyrol. 2013, 99, 143-148. [CrossRef]

21. Wu, C.; Wang, Z.; Huang, J.; Williams, P.T. Pyrolysis/gasification of cellulose, hemicellulose and lignin for hydrogen production in the presence of various nickel-based catalysts. Fuel 2013, 106, 697-706. [CrossRef]

22. Ryczkowski, R.; Ruppert, A.M.; Przybysz, P.; Chałupka, K.; Grams, J. Hydrogen production from biomass woodchips using $\mathrm{Ni} / \mathrm{CaO}-\mathrm{ZrO}_{2}$ catalysts. React. Kinet. Mech. Catal. 2017, 121, 97-107. [CrossRef] 
23. Furusawa, T.; Sato, T.; Sugito, H.; Miura, Y.; Ishiyama, Y.; Sato, M.; Itoh, N.; Suzuki, N. Hydrogen production from the gasification of lignin with nickel catalysts in supercritical water. Int. J. Hydrog. Energy 2007, 32, 699-704. [CrossRef]

24. Valle, B.; Remiro, A.; Aguayo, A.T.; Bilbao, J.; Gayubo, A.G. Catalysts of Ni/ $\alpha-\mathrm{Al}_{2} \mathrm{O}_{3}$ and Ni/La $2 \mathrm{O}_{3}-\alpha \mathrm{Al}_{2} \mathrm{O}_{3}$ for hydrogen production by steam reforming of bio-oil aqueous fraction with pyrolytic lignin retention. Int. J. Hydrog. Energy 2013, 38, 1307-1318. [CrossRef]

25. Remiro, A.; Valle, B.; Aramburu, B.; Aguayo, A.T.; Bilbao, J.; Gayubo, A.G. Steam reforming of the bio-oil aqueous fraction in a fluidized bed reactor with in situ $\mathrm{CO}_{2}$ capture. Ind. Eng. Chem. Res. 2013, 52, 17087-17098. [CrossRef]

26. Ochoa, A.; Aramburu, B.; Valle, B.; Resasco, D.E.; Bilbao, J.; Gayubo, A.G.; Castaño, P. Role of oxygenates and effect of operating conditions in the deactivation of a Ni supported catalyst during the steam reforming of bio-oil. Green Chem. 2017, 19, 4315-4333. [CrossRef]

27. Remiro, A.; Valle, B.; Aguayo, A.T.; Bilbao, J.; Gayubo, A.G. Steam Reforming of Raw Bio-oil in a Fluidized Bed Reactor with Prior Separation of Pyrolytic Lignin. Energy Fuels 2013, 27, 7549-7559. [CrossRef]

28. Remiro, A.; Arandia, A.; Bilbao, J.; Gayubo, A.G. Comparison of Ni based and Rh based catalyst performance in the oxidative steam reforming of raw bio-oil. Energy Fuels 2017, 31, 7147-7156. [CrossRef]

29. Remiro, A.; Valle, B.; Oar-Arteta, L.; Aguayo, A.T.; Bilbao, J.; Gayubo, A.G. Hydrogen production by steam reforming of bio-oil/bio-ethanol mixtures in a continuous thermal-catalytic process. Int. J. Hydrog. Energy 2014, 39, 6889-6898. [CrossRef]

30. Valle, B.; Aramburu, B.; Remiro, A.; Bilbao, J.; Gayubo, A.G. Effect of calcination/reduction conditions of $\mathrm{Ni} / \mathrm{La}_{2} \mathrm{O}_{3}-\alpha \mathrm{Al}_{2} \mathrm{O}_{3}$ catalyst on its activity and stability for hydrogen production by steam reforming of raw bio-oil/ethanol. Appl. Catal. B 2014, 147, 402-410. [CrossRef]

31. Nie, R.; Yang, H.; Zhang, H.; Yu, X.; Lu, X.; Zhou, D.; Xia, Q. Mild-temperature hydrodeoxygenation of vanillin over porous nitrogen-doped carbon black supported nickel nanoparticles. Green Chem. 2017, 19, 3126-3134. [CrossRef]

32. Phongpreecha, T.; Liu, J.; Hodge, D.B.; Qi, Y. Adsorption of Lignin $\beta-O-4$ Dimers on Metal Surfaces in Vacuum and Solvated Environments. ACS Sustain. Chem. Eng. 2019, 7, 2667-2678. [CrossRef]

33. Wang, X.; Rinaldi, R. Bifunctional Ni catalysts for the one-pot conversion of organosolv lignin into cycloalkanes. Catal. Today 2016, 269, 48-55. [CrossRef]

34. Jin, S.; Xiao, Z.; Li, C.; Chen, X.; Wang, L.; Xing, J.; Li, W.; Liang, C. Catalytic hydrodeoxygenation of anisole as lignin model compound over supported nickel catalysts. Catal. Today 2014, 234, 125-132. [CrossRef]

35. Jin, S.; Xiao, Z.; Chen, X.; Wang, L.; Guo, J.; Zhang, M.; Liang, C. Cleavage of lignin-derived 4-O-5 aryl ethers over nickel nanoparticles supported on niobic acid-activated carbon composites. Ind. Eng. Chem. Res. 2015, 54, 2302-2310. [CrossRef]

36. Wang, W.; Yang, Y.; Luo, H.; Peng, H.; Wang, F. Effect of La on Ni-W-B amorphous catalysts in hydrodeoxygenation of phenol. Ind. Eng. Chem. Res. 2011, 50, 10936-10942. [CrossRef]

37. Zuliani, A.; Balu, A.M.; Luque, R. Efficient and Environmentally Friendly Microwave-Assisted Synthesis of Catalytically Active Magnetic Metallic Ni Nanoparticles. ACS Sustain. Chem. Eng. 2017, 5, 11584-11587. [CrossRef]

38. Sankaranarayanan, T.M.; Berenguer, A.; Ochoa-Hernández, C.; Moreno, I.; Jana, P.; Coronado, J.M.; Serrano, D.P.; Pizarro, P. Hydrodeoxygenation of anisole as bio-oil model compound over supported $\mathrm{Ni}$ and Co catalysts: Effect of metal and support properties. Catal. Today 2015, 243, 163-172. [CrossRef]

39. Zhao, C.; Kou, Y.; Lemonidou, A.A.; Li, X.; Lercher, J.A. Hydrodeoxygenation of bio-derived phenols to hydrocarbons using Raney $\mathrm{Ni}$ and $\mathrm{Nafion} / \mathrm{SiO}_{2}$ catalysts. Chem. Commun. 2010, 46, 412-414. [CrossRef] [PubMed]

40. Zhang, X.; Zhang, Q.; Wang, T.; Ma, L.; Yu, Y.; Chen, L. Hydrodeoxygenation of lignin-derived phenolic compounds to hydrocarbons over $\mathrm{Ni} / \mathrm{SiO}_{2}-\mathrm{ZrO}_{2}$ catalysts. Bioresour. Technol. 2013, 134, 73-80. [CrossRef] [PubMed]

41. He, J.; Zhao, C.; Lercher, J.A. Ni-catalyzed cleavage of aryl ethers in the aqueous phase. J. Am. Chem. Soc. 2012, 134, 20768-20775. [CrossRef] 
42. Xu, C.; Tang, S.-F.; Sun, X.; Sun, Y.; Li, G.; Qi, J.; Li, X.; Li, X. Investigation on the cleavage of $\beta$-O-4 linkage in dimeric lignin model compound over nickel catalysts supported on $\mathrm{ZnO}-\mathrm{Al}_{2} \mathrm{O}_{3}$ composite oxides with varying Zn/Al ratios. Catal. Today 2017, 298, 89-98. [CrossRef]

43. Yang, L.; Seshan, K.; Li, Y. A review on thermal chemical reactions of lignin model compounds. Catal. Today 2017, 298, 276-297. [CrossRef]

44. Dongil, A.B.; Pastor-Pérez, L.; Sepúlveda-Escribano, A.; García, R.; Escalona, N. Hydrodeoxygenation of guaiacol: Tuning the selectivity to cyclohexene by introducing Ni nanoparticles inside carbon nanotubes. Fuel 2016, 172, 65-69. [CrossRef]

45. Zhang, X.; Tang, W.; Zhang, Q.; Wang, T.; Ma, L. Hydrodeoxygenation of lignin-derived phenoic compounds to hydrocarbon fuel over supported Ni-based catalysts. Appl. Energy 2018, 227, 73-79. [CrossRef]

46. Barton, R.R.; Carrier, M.; Segura, C.; Fierro, J.L.G.; Park, S.; Lamb, H.H.; Escalona, N.; Peretti, S.W. Ni/HZSM-5 catalyst preparation by deposition-precipitation. Part 2. Catalytic hydrodeoxygenation reactions of lignin model compounds in organic and aqueous systems. Appl. Catal. A 2018, 562, 294-309. [CrossRef]

47. Zhao, C.; Lercher, J.A. Upgrading pyrolysis oil over Ni/HZSM-5 by cascade reactions. Angew Chem. Int. Ed. Engl. 2012, 51, 5935-5940. [CrossRef] [PubMed]

48. Shu, R.; Xu, Y.; Ma, L.; Zhang, Q.; Chen, P.; Wang, T. Synergistic effects of highly active Ni and acid site on the hydrodeoxygenation of syringol. Catal. Commun. 2017, 91, 1-5. [CrossRef]

49. Tran, N.T.T.; Uemura, Y.; Chowdhury, S.; Ramli, A. Vapor-phase hydrodeoxygenation of guaiacol on Al-MCM-41 supported Ni and Co catalysts. Appl. Catal. A 2016, 512, 93-100. [CrossRef]

50. Long, J.; Shu, S.; Wu, Q.; Yuan, Z.; Wang, T.; Xu, Y.; Zhang, X.; Zhang, Q.; Ma, L. Selective cyclohexanol production from the renewable lignin derived phenolic chemicals catalyzed by Ni/MgO. Energy Convers. Manag. 2015, 105, 570-577. [CrossRef]

51. Dongil, A.B.; Ghampson, I.T.; García, R.; Fierro, J.L.G.; Escalona, N. Hydrodeoxygenation of guaiacol over $\mathrm{Ni}$ /carbon catalysts: effect of the support and Ni loading. RSC Adv. 2016, 6, 2611-2623. [CrossRef]

52. Yang, Y.; Ochoa-Hernández, C.; de la Peña O'Shea, V.A.; Pizarro, P.; Coronado, J.M.; Serrano, D.P. Effect of metal-support interaction on the selective hydrodeoxygenation of anisole to aromatics over Ni-based catalysts. Appl. Catal. B 2014, 145, 91-100. [CrossRef]

53. Jin, S.; Chen, X.; Li, C.; Tsang, C.-W.; Lafaye, G.; Liang, C. Hydrodeoxygenation of lignin-derived diaryl ethers to aromatics and alkanes using nickel on Zr-doped niobium phosphate. ChemistrySelect 2016, 1, 4949-4956. [CrossRef]

54. Berenguer, A.; Bennett, J.A.; Hunns, J.; Moreno, I.; Coronado, J.M.; Lee, A.F.; Pizarro, P.; Wilson, K.; Serrano, D.P. Catalytic hydrodeoxygenation of $\mathrm{m}$-cresol over $\mathrm{Ni}_{2} \mathrm{P} /$ hierarchical ZSM-5. Catal. Today 2018, 304, 72-79. [CrossRef]

55. Feitosa, L.F.; Berhault, G.; Laurenti, D.; Davies, T.E.; Teixeira da Silva, V. Synthesis and hydrodeoxygenation activity of $\mathrm{Ni} 2 \mathrm{P} / \mathrm{C}$ - Effect of the palladium salt on lowering the nickel phosphide synthesis temperature. J. Catal. 2016, 340, 154-165. [CrossRef]

56. Gonçalves, V.O.O.; de Souza, P.M.; da Silva, V.T.; Noronha, F.B.; Richard, F. Kinetics of the hydrodeoxygenation of cresol isomers over $\mathrm{Ni}_{2} \mathrm{P} / \mathrm{SiO}_{2}$ : Proposals of nature of deoxygenation active sites based on an experimental study. Appl. Catal. B 2017, 205, 357-367. [CrossRef]

57. Lan, X.; Hensen, E.J.M.; Weber, T. Hydrodeoxygenation of guaiacol over $\mathrm{Ni}_{2} \mathrm{P} / \mathrm{SiO}_{2}-$ reaction mechanism and catalyst deactivation. Appl. Catal. A 2018, 550, 57-66. [CrossRef]

58. Shu, R.; Zhang, Q.; Xu, Y.; Long, J.; Ma, L.; Wang, T.; Chen, P.; Wu, Q. Hydrogenation of lignin-derived phenolic compounds over step by step precipitated $\mathrm{Ni} / \mathrm{SiO}_{2}$. RSC Adv. 2016, 6, 5214-5222. [CrossRef]

59. Forchheim, D.; Hornung, U.; Kempe, P.; Kruse, A.; Steinbach, D. Influence of Raney nickel on the formation of intermediates in the degradation of lignin. Int. J. Chem. Eng. 2012, 2012, 1-8. [CrossRef]

60. Schutyser, W.; Van den Bosch, S.; Dijkmans, J.; Turner, S.; Meledina, M.; van Tendeloo, G.; Debecker, D.; Sels, B. Selective Ni-catalyzed conversion of model and lignin-derived phenoli compounds to cyclohexanone-based polymer building blocks. ChemSusChem 2015, 8, 1805-1818. [CrossRef]

61. Song, W.; Liu, Y.; Baráth, E.; Zhao, C.; Lercher, J.A. Synergistic effects of Ni and acid sites for hydrogenation and C-O bond cleavage of substituted phenols. Green Chem. 2015, 17, 1204-1218. [CrossRef] 
62. Wang, X.; Rinaldi, R. Solvent effects on the hydrogenolysis of diphenyl ether with Raney nickel and their implications for the conversion of lignin. ChemSusChem 2012, 5, 1455-1466. [CrossRef]

63. Li, C.; Zhao, X.; Wang, A.; Huber, G.W.; Zhang, T. Catalytic Transformation of Lignin for the Production of Chemicals and Fuels. Chem. Rev. 2015, 115, 11559-11624. [CrossRef]

64. Kong, J.; He, M.; Lercher, J.A.; Zhao, C. Direct production of naphthenes and paraffins from lignin. Chem. Commun. 2015, 51, 17580-17583. [CrossRef] [PubMed]

65. Kong, J.; Li, B.; Zhao, C. Tuning Ni nanoparticles and the acid sites of silica-alumina for liquefaction and hydrodeoxygenation of lignin to cyclic alkanes. RSC Adv. 2016, 6, 71940-71951. [CrossRef]

66. Feng, B.; Kobayashi, H.; Ohta, H.; Fukuoka, A. Aqueous-phase hydrodeoxygenation of 4-propylphenol as a lignin model to n-propylbenzene over Re-Ni/ZrO 2 catalysts. J. Mol. Catal. A Chem. 2014, 388, 41-46. [CrossRef]

67. Do, P.T.M.; Foster, A.J.; Chen, J.; Lobo, R.F. Bimetallic effects in the hydrodeoxygenation of meta-cresol on $\gamma-\mathrm{Al}_{2} \mathrm{O}_{3}$ supported Pt-Ni and Pt-Co catalysts. Green Chem. 2012, 14, 1388. [CrossRef]

68. Reddy Kannapu, H.P.; Mullen, C.A.; Elkasabi, Y.; Boateng, A.A. Catalytic transfer hydrogenation for stabilization of bio-oil oxygenates: Reduction of p-cresol and furfural over bimetallic Ni-Cu catalysts using isopropanol. Fuel Process. Technol. 2015, 137, 220-228. [CrossRef]

69. Mauriello, F.; Paone, E.; Pietropaolo, R.; Balu, A.M.; Luque, R. Catalytic transfer hydrogenolysis of lignin-derived aromatic ethers promoted by bimetallic Pd/Ni systems. ACS Sustain. Chem. Eng. 2018, 6, 9269-9276. [CrossRef]

70. Yang, F.; Liu, D.; Wang, H.; Liu, X.; Han, J.; Ge, Q.; Zhu, X. Geometric and electronic effects of bimetallic $\mathrm{Ni}-\mathrm{Re}$ catalysts for selective deoxygenation of m-cresol to toluene. J. Catal. 2017, 349, 84-97. [CrossRef]

71. Zhang, J.; Asakura, H.; van Rijn, J.; Yang, J.; Duchesne, P.; Zhang, B.; Chen, X.; Zhang, P.; Saeys, M.; Yan, N. Highly efficient, NiAu-catalyzed hydrogenolysis of lignin into phenolic chemicals. Green Chem. 2014, 16, 2432-2437. [CrossRef]

72. Joshi, N.; Lawal, A. Hydrodeoxygenation of 4-Propylguaiacol (2-Methoxy-4-propylphenol) in a microreactor: Performance and kinetic studies. Ind. Eng. Chem. Res. 2013, 52, 4049-4058. [CrossRef]

73. Sangnikul, P.; Phanpa, C.; Xiao, R.; Zhang, H.; Reubroycharoen, P.; Kuchonthara, P.; Vitidsant, T.; Pattiya, A.; Hinchiranan, N. Role of copper- or cerium-promoters on $\mathrm{NiMo} / \gamma-\mathrm{A}_{12} \mathrm{O}_{3}$ catalysts in hydrodeoxygenation of guaiacol and bio-oil. Appl. Catal. A 2019, 574, 151-160. [CrossRef]

74. Wang, H.; Ruan, H.; Feng, M.; Qin, Y.; Job, H.; Luo, L.; Wang, C.; Engelhard, M.H.; Kuhn, E.; Chen, X.; et al. One-pot process for hydrodeoxygenation of lignin to alkanes using Ru-based bimetallic and bifunctional catalysts supported on zeolite y. ChemSusChem 2017, 10, 1846-1856. [CrossRef] [PubMed]

75. Echeandia, S.; Arias, P.L.; Barrio, V.L.; Pawelec, B.; Fierro, J.L.G. Synergy effect in the HDO of phenol over $\mathrm{Ni}-\mathrm{W}$ catalysts supported on active carbon: Effect of tungsten precursors. Appl. Catal. B 2010, 101, 1-12. [CrossRef]

76. Jin, S.; Guan, W.; Tsang, C.-W.; Yan, D.Y.S.; Chan, C.-Y.; Liang, C. Enhanced hydroconversion of lignin-derived oxygen-containing compounds over bulk nickel catalysts though $\mathrm{Nb}_{2} \mathrm{O}_{5}$ modification. Catal. Lett. 2017, 147, 2215-2224. [CrossRef]

77. Li, C.; Jin, S.; Guan, W.; Tsang, C.-W.; Chu, W.-K.; Lau, W.K.; Liang, C. Chemical precipitation method for the synthesis of $\mathrm{Nb}_{2} \mathrm{O}_{5}$ modified bulk nickel catalysts with high specific surface area. J. Vis. Exp. 2018, 10, e56987. [CrossRef]

78. Luo, Z.; Zheng, Z.; Li, L.; Cui, Y.-T.; Zhao, C. Bimetallic Ru-Ni catalyzed aqueous-phase guaiacol hydrogenolysis at low $\mathrm{H}_{2}$ pressures. ACS Catal. 2017, 7, 8304-8313. [CrossRef]

79. Narani, A.; Chowdari, R.K.; Cannilla, C.; Bonura, G.; Frusteri, F.; Heeres, H.J.; Barta, K. Efficient catalytic hydrotreatment of Kraft lignin to alkylphenolics using supported NiW and NiMo catalysts in supercritical methanol. Green Chem. 2015, 17, 5046-5057. [CrossRef]

80. Meier, D.; Ante, R.; Faix, O. Catalytic hydropyrolysis of lignin - influence of reaction conditions on the formation and composition of liquid products. Bioresour. Technol. 1992, 40, 171-177. [CrossRef]

81. Oasmaa, A.; Alen, R.; Meier, D. Catalytic hydrotreatment of some technical lignins. Bioresour. Technol. 1993, 45, 189-194. [CrossRef]

82. Meier, D.; Berns, J.; Grunwald, C.; Faix, O. Analytical pyrolysis and semicontinuous catalytic hydropyrolysis of organocell lignin. J. Anal. Appl. Pyrol. 1993, 25, 335-347. [CrossRef] 
83. Kumar, C.R.; Anand, N.; Kloekhorst, A.; Cannilla, C.; Bonura, G.; Frusteri, F.; Barta, K.; Heeres, H.J. Solvent free depolymerization of Kraft lignin to alkyl-phenolics using supported NiMo and CoMo catalysts. Green Chem. 2015, 17, 4921-4930. [CrossRef]

84. Harris, E.E.; D'ianni, J.; Adkin, H. Reaction of hardwood lignin with hydrogen. J. Am. Chem. Soc. 1938, 60, 1467-1470. [CrossRef]

85. Duzee, E.M.V.; Adkins, H. Hydrogenation and hydrogenolysis of ethers. J. Am. Chem. Soc. 1935, 57, $147-151$. [CrossRef]

86. Chandler, G.S.; Sass, W.H.F. Synthetical applications of activated metal catalysts xvii. The hydrogenolysis of aromatic ethers by Raney nickel. Aust. J. Chem. 1963, 16, 20-30. [CrossRef]

87. Liang, S.; Wan, C. Biorefinery Lignin to Renewable Chemicals via Sequential Fractionation and Depolymerization. Waste Biomass Valorization 2017, 8, 393-400. [CrossRef]

88. Strueven, J.O.; Meier, D. Hydrocracking of organosolv lignin in subcritical water to useful phenols employing various Raney nickel catalysts. ACS Sustain. Chem. Eng. 2016, 4, 3712-3721. [CrossRef]

89. Lam, C.H.; Lowe, C.B.; Li, Z.; Longe, K.N.; Rayburn, J.T.; Caldwell, M.A.; Houdek, C.E.; Maguire, J.B.; Saffron, C.M.; Miller, D.J.; et al. Electrocatalytic upgrading of model lignin monomers with earth abundant metal electrodes. Green Chem. 2015, 17, 601-609. [CrossRef]

90. Gomez-Monedero, B.; Ruiz, M.P.; Bimbela, F.; Faria, J. Selective hydrogenolysis of $\alpha-\mathrm{O}-4, \beta-\mathrm{O}-4,4-\mathrm{O}-5$ $\mathrm{C}-\mathrm{O}$ bonds of lignin-model compounds and lignin-containing stillage derived from cellulosic bioethanol processing. Appl. Catal. A 2017, 541,60-76. [CrossRef]

91. Song, Q.; Wang, F.; Cai, J.; Wang, Y.; Zhang, J.; Yu, W.; Xu, J. Lignin depolymerization (LDP) in alcohol over nickel-based catalysts via a fragmentation-hydrogenolysis process. Energy Environ. Sci. 2013, 6, 994-1007. [CrossRef]

92. Song, Q.; Wang, F.; Xu, J. Hydrogenolysis of lignosulfonate into phenols over heterogeneous nickel catalysts. Chem. Commun. 2012, 48, 7019-7021. [CrossRef]

93. Matsagar, B.M.; Kang, T.-C.; Wang, Z.-Y.; Yoshikawa, T.; Nakasaka, Y.; Masuda, T.; Chuang, L.-C.; Wu, K.C.W. Efficient liquid-phase hydrogenolysis of a lignin model compound (benzyl phenyl ether) using a Ni/carbon catalyst. React. Chem. Eng. 2019, 4, 618-626. [CrossRef]

94. Wang, S.Z.; Gao, W.; Xiao, L.P.; Shi, J.; Sun, R.C.; Song, G.Y. Hydrogenolysis of biorefinery corncob lignin into aromatic phenols over activated carbon-supported nickel. Sustain. Energ. Fuels 2019, 3, 401-408. [CrossRef]

95. Chen, J.; Lu, F.; Si, X.; Nie, X.; Chen, J.; Lu, R.; Xu, J. High yield production of natural phenolic alcohols from woody biomass using a Nickel-based catalyst. ChemSusChem 2016, 9, 3353-3360. [CrossRef] [PubMed]

96. Anderson, E.M.; Katahira, R.; Reed, M.; Resch, M.G.; Karp, E.M.; Beckham, G.T.; Román-Leshkov, Y. Reductive Catalytic Fractionation of Corn Stover Lignin. ACS Sustain. Chem. Eng. 2016, 4, 6940-6950. [CrossRef]

97. Li, J.; Sun, H.; Liu, J.-x.; Zhang, J.-j.; Li, Z.-x.; Fu, Y. Selective reductive cleavage of C-O bond in lignin model compounds over nitrogen-doped carbon-supported iron catalysts. Mol. Catal. 2018, 452, 36-45. [CrossRef]

98. Lama, S.M.G.; Pampel, J.; Fellinger, T.-P.; Beskoski, V.P.; Slavkovic-Beskoski, L.; Antonietti, M.; Molinari, V. Efficiency of Ni nanoparticles supported on hierarchical porous nitrogen-doped carbon for hydrogenolysis of Kraft lignin in flow and batch systems. ACS Sustain. Chem. Eng. 2017, 5, 2415-2420. [CrossRef]

99. Wang, M.; Zhang, X.; Li, H.; Lu, J.; Liu, M.; Wang, F. Carbon Modification of Nickel Catalyst for Depolymerization of Oxidized Lignin to Aromatics. ACS Catal. 2018, 8, 1614-1620. [CrossRef]

100. Chen, P.; Zhang, Q.; Shu, R.; Xu, Y.; Ma, L.; Wang, T. Catalytic depolymerization of the hydrolyzed lignin over mesoporous catalysts. Bioresour. Technol. 2017, 226, 125-131. [CrossRef]

101. Toledano, A.; Serrano, L.; Pineda, A.; Romero, A.A.; Luque, R.; Labidi, J. Microwave-assisted depolymerisation of organosolv lignin via mild hydrogen-free hydrogenolysis: Catalyst screening. Appl. Catal. B 2014, 145, 43-55. [CrossRef]

102. Toledano, A.; Serrano, L.; Labidi, J.; Pineda, A.; Balu, A.M.; Luque, R. Heterogeneously catalysed mild hydrogenolytic depolymerisation of lignin under microwave irradiation with hydrogen-donating solvents. Chem CatChem 2013, 5, 977-985. [CrossRef]

103. Toledano, A.; Serrano, L.; Balu, A.M.; Luque, R.; Pineda, A.; Labidi, J. Fractionation of Organosolv Lignin from Olive Tree Clippings and its Valorization to Simple Phenolic Compounds. Chemsuschem 2013, 6, 529-536. [CrossRef] 
104. Zhou, L.; Wu, Q.; Xu, Y.; Wang, C.; Ma, L.; Li, W.; Chen, P. Depolymerization of the alkali lignin for aromatic compounds over $\mathrm{Ni} / \mathrm{SiO}_{2}-\mathrm{Al}_{2} \mathrm{O}_{3}$ solid acid catalysts. Chem. J. Chin. Univ. 2018, 39, 735-742. [CrossRef]

105. Kasakov, S.; Shi, H.; Camaioni, D.M.; Zhao, C.; Barath, E.; Jentys, A.; Lercher, J.A. Reductive deconstruction of organosolv lignin catalyzed by zeolite supported nickel nanoparticles. Green Chem. 2015, 17, 5079-5090. [CrossRef]

106. Zaheer, M.; Hermannsdoerfer, J.; Kretschmer, W.P.; Motz, G.; Kempe, R. Robust Heterogeneous Nickel Catalysts with Tailored Porosity for the Selective Hydrogenolysis of Aryl Ethers. ChemCatChem 2014, 6, 91-95. [CrossRef]

107. Xin, J.; Zhang, P.; Wolcott, M.P.; Zhang, X.; Zhang, J. Partial depolymerization of enzymolysis lignin via mild hydrogenolysis over Raney nickel. Bioresour. Technol. 2014, 155, 422-426. [CrossRef] [PubMed]

108. Li, C.; Zheng, M.; Wang, A.; Zhang, T. One-pot catalytic hydrocracking of raw woody biomass into chemicals over supported carbide catalysts: simultaneous conversion of cellulose, hemicellulose and lignin. Energy Environ. Sci. 2012, 5, 6383-6390. [CrossRef]

109. Ma, X.; Tian, Y.; Hao, W.; Ma, R.; Li, Y. Production of phenols from catalytic conversion of lignin over a tungsten phosphide catalyst. Appl. Catal. A 2014, 481, 64-70. [CrossRef]

110. Molinari, V.; Giordano, C.; Antonietti, M.; Esposito, D. Titanium nitride-nickel nanocomposite as heterogeneous catalyst for the hydrogenolysis of aryl ethers. J. Am. Chem. Soc. 2014, 136, 1758-1761. [CrossRef] [PubMed]

111. Molinari, V.; Clavel, G.; Graglia, M.; Antonietti, M.; Esposito, D. Mild continuous hydrogenolysis of Kraft lignin over titanium nitride-nickel catalyst. ACS Catal. 2016, 6, 1663-1670. [CrossRef]

112. Yang, X.; Feng, M.; Choi, J.-S.; Meyer, H.M.; Yang, B. Depolymerization of corn stover lignin with bulk molybdenum carbide catalysts. Fuel 2019, 244, 528-535. [CrossRef]

113. Li, R.; Li, B.; Yang, T.; Kai, X.; Zhang, W. Hydrogenation of rice stalk in situ in supercritical ethanol-water co-solvent via catalytic ethanol steam reforming. J. Supercrit. Fluids 2018, 133, 309-317. [CrossRef]

114. Loefstedt, J.; Dahlstrand, C.; Orebom, A.; Meuzelaar, G.; Sawadjoon, S.; Galkin, M.V.; Agback, P.; Wimby, M.; Corresa, E.; Mathieu, Y.; et al. Green diesel from Kraft lignin in three steps. ChemSusChem 2016, 9, 1392-1396. [CrossRef] [PubMed]

115. Zhai, Y.; Li, C.; Xu, G.; Ma, Y.; Liu, X.; Zhang, Y. Depolymerization of lignin via a non-precious Ni-Fe alloy catalyst supported on activated carbon. Green Chem. 2017, 19, 1895-1903. [CrossRef]

116. Regmi, Y.N.; Mann, J.K.; McBride, J.R.; Tao, J.; Barnes, C.E.; Labbé, N.; Chmely, S.C. Catalytic transfer hydrogenolysis of organosolv lignin using B-containing FeNi alloyed catalysts. Catal. Today 2018, 302, 190-195. [CrossRef]

117. Kong, L.; Liu, C.; Gao, J.; Wang, Y.; Dai, L. Efficient and controllable alcoholysis of Kraft lignin catalyzed by porous zeolite-supported nickel-copper catalyst. Bioresour. Technol. 2019, 276, 310-317. [CrossRef] [PubMed]

118. Ambursa, M.M.; Sudarsanam, P.; Voon, L.H.; Hamid, S.B.A.; Bhargava, S.K. Bimetallic Cu-Ni catalysts supported on MCM-41 and Ti-MCM-41 porous materials for hydrodeoxygenation of lignin model compound into transportation fuels. Fuel Process. Technol. 2017, 162, 87-97. [CrossRef]

119. Chen, B.; Li, F.; Yuan, G. Highly Stable and Recyclable Graphene Layers Protected Nickel-Cobalt Bimetallic Nanoparticles as Tunable Hydrotreating Catalysts for Phenylpropane Linkages in Lignin. Catal. Lett. 2017, 147, 2877-2885. [CrossRef]

120. Wang, D.; Wang, Y.; Li, X.; Chen, L.; Li, G.; Li, X. Lignin Valorization: A Novel in Situ Catalytic Hydrogenolysis Method in Alkaline Aqueous Solution. Energy Fuels 2018, 32, 7643-7651. [CrossRef]

121. Zhang, J.-w.; Lu, G.-p.; Cai, C. Self-hydrogen transfer hydrogenolysis of $\beta$-O-4 linkages in lignin catalyzed by MIL-100(Fe) supported Pd-Ni BMNPs. Green Chem. 2017, 19, 4538-4543. [CrossRef]

122. Sun, K.-k.; Lu, G.-p.; Zhang, J.-w.; Cai, C. The selective hydrogenolysis of C-O bonds in lignin model compounds by Pd-Ni bimetallic nanoparticles in ionic liquids. Dalton Trans. 2017, 46, 11884-11889. [CrossRef]

123. Zhang, J.-w.; Cai, Y.; Lu, G.-p.; Cai, C. Facile and selective hydrogenolysis of $\beta-\mathrm{O}-4$ linkages in lignin catalyzed by Pd-Ni bimetallic nanoparticles supported on $\mathrm{ZrO}_{2}$. Green Chem. 2016, 18, 6229-6235. [CrossRef]

124. Zhang, J.; Ibrahim, M.; Colliere, V.; Asakura, H.; Tanaka, T.; Teramura, K.; Philippot, K.; Yan, N. $\mathrm{Rh}$ nanoparticles with $\mathrm{NiO}_{\mathrm{x}}$ surface decoration for selective hydrogenolysis of $\mathrm{C}-\mathrm{O}$ bond over arene hydrogenation. J. Mol. Catal. A Chem. 2016, 422, 188-197. [CrossRef] 
125. Hu, Y.; Jiang, G.; Xu, G.; Mu, X. Hydrogenolysis of lignin model compounds into aromatics with bimetallic Ru-Ni supported onto nitrogen-doped activated carbon catalyst. Mol. Catal. 2018, 445, 316-326. [CrossRef]

126. Verziu, M.; Tirsoaga, A.; Cojocaru, B.; Bucur, C.; Tudora, B.; Richel, A.; Aguedo, M.; Samikannu, A.; Mikkola, J.P. Hydrogenolysis of lignin over Ru-based catalysts: The role of the ruthenium in a lignin fragmentation process. Mol. Catal. 2018, 450, 65-76. [CrossRef]

127. Zhang, J.; Teo, J.; Chen, X.; Asakura, H.; Tanaka, T.; Teramura, K.; Yan, N. A series of NiM (M = Ru, Rh, and Pd) bimetallic catalysts for effective lignin hydrogenolysis in water. ACS Catal. 2014, 4, 1574-1583. [CrossRef]

128. Konnerth, H.; Zhang, J.; Ma, D.; Prechtl, M.H.G.; Yan, N. Base promoted hydrogenolysis of lignin model compounds and organosolv lignin over metal catalysts in water. Chem. Eng. Sci. 2015, 123, 155-163. [CrossRef]

129. Zhang, J.; Yan, N. NiAg catalysts for selective hydrogenolysis of the lignin C-O bond. Part. Part. Syst. Charact. 2016, 33, 610-619. [CrossRef]

130. Sergeev, A.G.; Hartwig, J.F. Selective nickel-catalyzed hydrogenolysis of aryl ethers. Science 2011, 332, 439-443. [CrossRef]

131. Sankar, M.; Dimitratos, N.; Miedziak, P.J.; Wells, P.P.; Kiely, C.J.; Hutchings, G.J. Designing bimetallic catalysts for a green and sustainable future. Chem. Soc. Rev. 2012, 41, 8099-8139. [CrossRef]

132. Wang, W.; Wu, K.; Liu, P.; Li, L.; Yang, Y.; Wang, Y. Hydrodeoxygenation of $p$-Cresol over Pt/ $\mathrm{Al}_{2} \mathrm{O}_{3}$ catalyst promoted by $\mathrm{ZrO}_{2}, \mathrm{CeO}_{2}$, and $\mathrm{CeO}_{2}-\mathrm{ZrO}_{2}$. Ind. Eng. Chem. Res. 2016, 55, 7598-7603. [CrossRef]

133. Shao, Y.; Xia, Q.; Dong, L.; Liu, X.; Han, X.; Parker, S.F.; Cheng, Y.; Daemen, L.L.; Ramirez-Cuesta, A.J.; Yang, S.; et al. Selective production of arenes via direct lignin upgrading over a niobium-based catalyst. Nat. Commun. 2017, 8, 16104. [CrossRef]

134. Li, X.H.; Antonietti, M. Metal nanoparticles at mesoporous N-doped carbons and carbon nitrides: functional Mott-Schottky heterojunctions for catalysis. Chem. Soc. Rev. 2013, 42, 6593-6604. [CrossRef] [PubMed]

135. Ji, N.; Zhang, T.; Zheng, M.; Wang, A.; Wang, H.; Wang, X.; Chen, J.G. Direct catalytic conversion of cellulose into ethylene glycol using nickel-promoted tungsten carbide catalysts. Angew Chem. Int. Ed. Engl. 2008, 47, 8510-8513. [CrossRef] [PubMed]

136. Mathey, F. Phospha-organic chemistry: panorama and perspectives. Angew Chem. Int. Ed. Engl. 2003, 42, 1578-1604. [CrossRef] [PubMed]

137. Wang, H.; Ruan, H.; Pei, H.; Wang, H.; Chen, X.; Tucker, M.P.; Cort, J.R.; Yang, B. Biomass-derived lignin to jet fuel range hydrocarbons via aqueous phase hydrodeoxygenation. Green Chem. 2015, 17, 5131-5135. [CrossRef]

138. Chin, Y.; King, D.; Roh, H.; Wang, Y.; Heald, S. Structure and reactivity investigations on supported bimetallic AuNi catalysts used for hydrocarbon steam reforming. J. Catal. 2006, 244, 153-162. [CrossRef]

139. Wang, X.; Perret, N.; Delgado, J.J.; Blanco, G.; Chen, X.; Olmos, C.M.; Bernal, S.; Keane, M.A. Reducible support effects in the gas phase hydrogenation of $p$-chloronitrobenzene over gold. J. Phys. Chem. C 2013, 117, 994-1005. [CrossRef]

140. Jin, G.-P.; Baron, R.; Rees, N.V.; Xiao, L.; Compton, R.G. Magnetically moveable bimetallic (nickel/silver) nanoparticle/carbon nanotube composites for methanol oxidation. New J. Chem. 2009, 33, 107-111. [CrossRef]

141. Yang, L.; Luo, W.; Cheng, G. Graphene-supported Ag-based core-shell nanoparticles for hydrogen generation in hydrolysis of ammonia borane and methylamine borane. ACS Appl. Mater. Interfaces 2013, 5, 8231-8240. [CrossRef]

142. Pepper, J.M.; Steck, W.F.; Swoboda, R.; Karapall, J.C. Hydrogenation of lignin using nickel and palladium catalysts. Adv. Chem. Ser. 1966, 59, 238-248.

143. Pepper, J.M.; Lee, Y.W. Lignin and related compounds.2. Studies using ruthenium and raney nickel as catalysts for lignin hydrogenolysis. Can. J. Chem. 1970, 48, 477-479. [CrossRef]

144. Pepper, J.M.; Lee, Y.W. Lignin and related compounds.I. A comparative study of catalysts for lignin hydrogenolysis. Can. J. Chem. 1969, 47, 723-727. [CrossRef]

145. Chesi, C.; de Castro, I.B.D.; Clough, M.T.; Ferrini, P.; Rinaldi, R. The influence of hemicellulose sugars on product distribution of early-stage conversion of lignin oligomers catalysed by Raney nickel. ChemCatChem 2016, 8, 2079-2088. [CrossRef] 
146. Van den Bosch, S.; Renders, T.; Kennis, S.; Koelewijn, S.F.; Van den Bossche, G.; Vangeel, T.; Deneyer, A.; Depuydt, D.; Courtin, C.M.; Thevelein, J.M.; et al. Integrating lignin valorization and bio-ethanol production: on the role of $\mathrm{Ni}-\mathrm{Al}_{2} \mathrm{O}_{3}$ catalyst pellets during lignin-first fractionation. Green Chem. 2017, 19, 3313-3326. [CrossRef]

147. Klein, I.; Saha, B.; Abu-Omar, M.M. Lignin depolymerization over Ni/C catalyst in methanol, a continuation: effect of substrate and catalyst loading. Catal. Sci. Technol. 2015, 5, 3242-3245. [CrossRef]

148. Luo, H.; Klein, I.M.; Jiang, Y.; Zhu, H.Y.; Liu, B.Y.; Kenttamaa, H.I.; Abu-Omar, M.M. Total utilization of Miscanthus biomass, lignin and carbohydrates, using earth abundant nickel catalyst. ACS Sustain. Chem. Eng. 2016, 4, 2316-2322. [CrossRef]

149. Yang, K.X.; Chen, X.; Lafaye, G.; Especel, C.; Epron, F.; Liang, C.H. One-step modification of active sites and support in $\mathrm{Ni} / \mathrm{Al}_{2} \mathrm{O}_{3}$ catalyst for hydrodeoxygenation of lignin-derived diphenyl ether. ChemistrySelect 2018, 3, 11398-11405. [CrossRef]

(C) 2019 by the authors. Licensee MDPI, Basel, Switzerland. This article is an open access article distributed under the terms and conditions of the Creative Commons Attribution (CC BY) license (http://creativecommons.org/licenses/by/4.0/). 